\title{
Predators and Parasitoids-in-First: From Inundative Releases to Preventative Biological Control in Greenhouse Crops
}

\author{
Juliette Pijnakker*, Dominiek Vangansbeke, Marcus Duarte, Rob Moerkens and \\ Felix L. Wäckers
}

R\&D Department, Biobest Group NV, Westerlo, Belgium

Repeated mass introductions of natural enemies have been widely used as a biological control strategy in greenhouse systems when the resident population of natural enemies is insufficient to suppress the pests. As an alternative strategy, supporting the establishment and population development of beneficials can be more effective and economical. The preventative establishment of predators and parasitoids, before the arrival of pests, has become a key element to the success of biological control programs.

OPEN ACCESS

Edited by:

Helda Morales,

The South Border College (ECOSUR), Mexico

Reviewed by:

Charles MacVean, York College of Pennsylvania,

United States

Kris A. G. Wyckhuys,

Chinese Academy of Agricultural

Sciences (CAAS), China

*Correspondence:

Juliette Pijnakker

juliette.pijnakker@biobestgroup.com

Specialty section:

This article was submitted to Agroecology and Ecosystem Services,

a section of the journal

Frontiers in Sustainable Food Systems

Received: 17 August 2020 Accepted: 03 November 2020 Published: 23 December 2020

Citation:

Pijnakker J, Vangansbeke $D$,

Duarte $M$, Moerkens $R$ and Wäckers FL (2020) Predators and

Parasitoids-in-First: From Inundative

Releases to Preventative Biological

Control in Greenhouse Crops.

Front. Sustain. Food Syst. 4:595630.

doi: 10.3389/fsufs.2020.595630
This "Predators and parasitoids-in-first" strategy is used both in Inoculative Biological Control (IBC), and in Conservation Biological Control (CBC). Here, we provide an overview of tools used to boost resident populations of biocontrol agents.

Keywords: biological control, conservation, standing army, bodyguards, predators, factitious prey, pollen, nectar

\section{INTRODUCTION}

Biological control in greenhouses dates back almost 100 years, when Speyer (1927) at the Cheshunt Experimental Station first described the control of greenhouse whitefly Trialeurodes vaporariorum (Westwood) by the specialist parasitoid Encarsia formosa Gahan (Hussey et al., 1969). This example was followed in the fifties by the use of the natural enemies against mealybugs (Doutt, 1951) and in the sixties, by the introductions of the specialist predatory mite Phytoseiulus persimilis Athias-Henriot for the control of spider mites (Bravenboer and Dosse, 1962). Biological control in greenhouses has since been extended by the addition of generalist biocontrol agents to complement the specialist beneficials (Janssen and Sabelis, 2015). The release of generalists, that can feed on a range of prey, but may also exploit non-prey food, made it possible to maintain populations of natural enemies in crops in absence of the target pest, thus facilitating the preventative use of natural enemies.

Thirty years ago, Ramakers (1990) proposed the concept of "predator-in-first" and stated that the availability of supplementary foods, such as pollen and nectar, is essential for early establishment of generalist natural enemies. However, many cropping systems lack these floral resources (Wäckers et al., 2005). As a result, most biological control programmes rely on inundative release strategies, where natural enemies are periodically introduced in large numbers to control pest problems (Stinner, 1977; Van Lenteren et al., 2003; Collier and Van Steenwyk, 2004). The pest control in inundative strategies often relies on the released individuals, rather than their progeny (De Bach, 1964). In ornamentals especially, cheap predators and parasitoids are released weekly in crops without necessarily accomplishing establishment (Hoddle et al., 1997, 1998; Buitenhuis et al., 2014, 2015). Manual and automatized blowers of beneficials have been specially designed for that purpose 
(Van Schelt et al., 2008). Inundative biological control strategies have among others the drawback to exclude more clostly, but more efficient natural enemies, like predatory bugs.

In recent years, there has been an increased interest in strategies to allow a preventative establishment of natural enemies (standing army) (Messelink et al., 2014; Pijnakker et al., 2017). Both Inoculative Biological Control (IBC), which aims at establishing mass-reared natural enemies, and Conservation Biological Control (CBC), that seeks to conserve or enhance naturally occurring biocontrol organisms, can benefit by providing natural enemies with missing resources (Hagen, 1986; Zemek and Prenerová, 1997; Wäckers, 2005). In biological control programs substantial advancements have been made in the use of factitious prey, pollen (extrafloral) nectar, and honeydew as food supplements (Van Rijn et al., 2002; Wäckers et al., 2005; Lundgren, 2009; Messelink et al., 2014). In addition, some predators can feed on plant tissues, which facilitates their establishment in periods of prey scarcity or in the absence of prey (Eubanks and Denno, 1999; Lucas and Alomar, 2001; Pappas et al., 2017). Besides the role of non-prey food, establishment of predators can also be supported through the provisioning of additional non-food resources, like shelter and oviposition sites (Messelink et al., 2014; Pekas and Wäckers, 2017). The advances in the use of supplementary resources to support early establishment of natural enemies in greenhouse crops are the focus of this review. Microbial control is not developed in this review, as preventative use of insect-pathogenic and antagonistic fungi is complex, there are few studies and results are inconsistent (Elliot et al., 2000).

\section{PLANT-TISSUE FEEDING}

While plant feeding by omnivorous biocontrol organisms can potentially cause plant damage (see below), using tissue-feeding omnivores as biological control agents has many advantages. They have been traditionally underestimated in inundative release biocontrol strategies (Castañé et al., 2011); however, several recent studies emphasize its importance (Coll and Guershon, 2002; Eubanks and Styrsky, 2005; Wäckers et al., 2005; Castañé et al., 2011; Pappas et al., 2017). Plant-tissue feeding plays a major role in the survival of several omnivores, as it has been shown to occur broadly in heteropterans (Ridgway and Jones, 1968; Naranjo and Gibson, 1996), as well as in a number of phytoseiid mites (Tanigoshi et al., 1993). In Heteroptera it provides nutrients that are essential to successful development (Gillespie and McGregor, 2000; Sinia et al., 2004) and may help them persist in periods of drought. Plant-tissue feeding is also assumed to provide some crucial resources that facilitate prey consumption. When consuming prey, some predatory Heteroptera require a source of water to dilute the digestive enzymes they inject into their prey (Cohen, 1985). Plant-tissue feeding may allow the Heteroptera to balance nutrients, proteins, carbohydrates, vitamins and minerals that would otherwise be restricted in a carnivorous diet (Polis et al., 1989; Coll, 1998). Particular plant species allow a full development of omnivorous Heteroptera in absence of prey. As omnivores can rely on tissue feeding, the risk of dying or leaving the crop at low prey densities is probably limited (Crawley, 1975; Pimm and Lawton, 1978), but will depend on the plant species.

While the induction of plant resistance mechanisms in response to herbivore feeding has been widely studied, few studies have addressed the effect of plant-tissue feeding by omnivore natural enemies in terms of plant defense induction (Stout et al., 1997; Agrawal et al., 1999; Agrawal and Klein, 2000; Agrawal, 2005a,b; Pappas et al., 2017). Induced plant resistance mechanisms include the production of secondary metabolites, part of which are released as volatile chemicals (Herbivoreinduced plant volatiles, HIPVs) (Paré and Tumlinson, 1999). HIPV's play an important role in protecting the damage sites against entry by pathogens. The induced change in plant chemistry can reduce plant attractiveness to herbivores, as well as herbivore performance (Turlings et al., 1990, Bolter et al., 1997; Karban and Baldwin, 1997; De Moraes et al., 2001; Kalberer et al., 2001; Wakefield et al., 2005), thus representing an important example of direct plant defense. An indirect defense mechanism is involved when HIPV's are used by the herbivore's natural enemies to locate their prey/hosts (Turlings and Wäckers, 2004). In addition, plant-tissue feeding also elicits the production of extrafloral nectar, an indirect defensive trait which allows plants to recruit ants and other nectar feeding omnivores, which in turn protect the plants by attacking the herbivores (Wäckers and Bonifay, 2004; Kost and Heil, 2005). Several studies have now demonstrated that plant-tissue feeding by predators also activates plant defense mechanisms (Pérez-Hedo et al., 2015a,b; Naselli et al., 2016; Pappas et al., 2016; Zhang et al., 2018). Plants with activated defense systems are less attractive to the tobacco whitefly Bemisia tabaci (Gennadius), but more attractive to the whitefly parasitoid E. formosa. Pappas et al. (2015) showed that the zoophytophagous predator Macrolophus pygmaeus Rambur induces defense of tomato plants, making them less susceptible to the two-spotted spider mite Tetranychus urticae Koch, but without affecting the greenhouse whitefly $T$. vaporariorum. Zhang et al. (2018) demonstrated that T. urticae and Western flower thrips Frankliniella occidentalis (Pergande) laid fewer eggs on sweet pepper plants previously inoculated with M. pygmaeus. As this also applied to newly produced leaves, which were not directly exposed to the omnivore, this suggests that the induced plant response is systemic. The development time of $F$. occidentalis larvae feeding on leaves previously exposed to $M$. pygmaeus was also prolonged.

The introduction of omnivores as biological control agents can create complex interactions. The ability of omnivores to feed on multiple trophic levels may not improve biological control. The possible benefits of plant-tissue feeding are omnivore specific and dependent on the developmental stage, prey availability and plant nutritional composition (Naranjo and Gibson, 1996). The complexity of food choice by omnivores remains poorly understood: in some cases, prey consumption is reduced when both prey and plant diets are available (Crum et al., 1998, Kiman and Yeargan, 1985, Weiser and Stamp, 1998). Feeding on highquality plant food may provide a highly nutritious preferred food source and decrease the consumption of a particular prey species (Abrams, 1987). Omnivorous bugs consumed fewer prey 
on plants presenting lima bean pods in a study by Eubanks and Denno (1999). Plant-tissue feeding often facilitates survival rather than reproduction probably because of low nitrogen contents (De Clercq and Degheele, 1992). Population dynamics can be strongly influenced by the developmental stage (Coll and Guershon, 2002), the period of phytophagy of the omnivores (Cisneros and Rosenheim, 1997) or by the competition for plant food between omnivores and prey (Polis and Holt, 1992; Coll and Izraylevich, 1997).

Concerning the impact of induced changes in host plant chemistry on pests and beneficials, Ode (2006) underlined that this aspect has been insufficiently explored and reviewed negative tritrophic effects of inducible plant defenses on natural enemies. In a study by Agrawal et al. (2002), predatory mites were less attracted to plants that produced cucurbitacins than cucurbitacin-free plants and had a reduced fecundity when feeding on herbivores that feed on defended plants when compared to those that fed on plants free of cucurbitacins. Induced plant resistance is thus not always favorable to biological control.

Using phytophagous beneficials also has the consequence that their plant feeding exposes them to systemic pesticides (Coll, 1998; Smith and Krischik, 1999, Arnó and Gabarra, 2011; Prabhaker et al., 2011; Put et al., 2015). Plant feeding by omnivores can also result in crop damage or reduced crop growth, in particular at high omnivore populations. Omnivores can cause direct mechanical feeding injuries, injuries to plant vascular tissues or damage through the salivary enzymes killing plant cells (Castañé et al., 2011). Plant-tissue feeding heteropterans can also disturb plant hormonal balances (Zhang et al., 2018). In tomatoes, fruit damage by heteropterans is often reported, reflecting a preference for the more nutritious tomato fruit (Salamero et al., 1987; Alomar et al., 1991; Lucas and Alomar, 2002; Albajes et al., 2006; Castañé et al., 2011). Nesidiocoris tenuis (Reuter) is known to cause injuries on the aerial parts of tomato plants (necrotic rings on stems, shoots, leaf petioles and flower stalks), leading to flowers and fruits abortion, and, reduced growth (Arnó et al., 2010). Gillespie et al. (2007) reported damage on gerbera flowers, Castañé et al. (2003) and Sengonça et al. (2003) on cucumber and zucchini fruit.

Despite the above negative aspects, omnivores are crucial elements in biological control strategies, especially mirids in tomato crops and anthocorids in sweet pepper crops. Current biological control programmes are supported with different tools like smart-phone applications to register and follow crop injuries and sticky traps to monitor omnivores and the pests. This allows growers to maximize benefits of omnivores and avoid risks. Omnivorous predators are commonly used in greenhouse crops and their establishment is even stimulated by provision of alternative food (Lenfant et al., 2000; Castañé et al., 2006; Put et al., 2012; Moerkens et al., 2017; Brenard et al., 2019; Sade et al., 2019). Growers try to avoid applications of systemic pesticides, which are not compatible with omnivores. Resistance breeding does not yet take plant suitability for omnivores into account, but this might change as we gain further insights in the complex interactions involving omnivores.

\section{PEST FEEDING (PEST-IN-FIRST)}

The "pest-in-first" (PIF) strategy is one of the oldest strategies to allow the establishment of a biocontrol "standing army" in greenhouses. Here an early introduction of natural enemies is combined with a controlled (pre-) release of the pest. This concept can also be used to allow early establishment of specialist natural enemies, which cannot be supported by factitious prey or pollen. One of the first examples of a successful PIF strategy is the release of two-spotted spider mites to reinforce the establishment of the predatory mite $P$. persimilis (Hussey et al., 1965; Gould et al., 1969; Markkula and Tiittanen, 1976; Havelka and Kindlmann, 1984; Waite, 2001; Bolckmans and Tetteroo, 2002). Other pest-in-first strategies have been evaluated, such as the introduction of low numbers of greenhouse whitefly T. vaporariorum in tomato followed by timed releases of its parasitoid E. formosa (Parr et al., 1976). Growers, however, are typically reluctant to release pests due to the risks of causing crop damage (Parr et al., 1976; Stacey, 1977, Starý, 1993). Instead, they prefer to wait until the pest develops naturally before introducing biocontrol, as releasing $P$. persimilis in naturally occurring $T$. urticae hot spots is often cheaper. Alternatively, they opt for calendar introductions of biocontrol agents.

\section{FACTITIOUS PREY}

To allow early establishment of generalist predators, growers can use factitious prey (i.e., foods which the predators usually do not encounter in their natural habitat). Some factitious prey, such as eggs of the Mediterranean flour moth, Ephestia kuehniella Zeller, decapsulated cysts of the brine shrimp Artemia spp. and astigmatid mites (Hoogerbrugge et al., 2008; Midthassel et al., 2013; Nguyen et al., 2014a; Delisle et al., 2015a; Labbé et al., 2018) can be excellent food sources for a wide range of generalist predators. Studies on these supplemental foods are summarized in Table 1. Some of these factitious prey, especially E. kuehniella eggs and astigmatid prey mites, are also used in the commercial production of biological control agents.

\section{Astigmatid Prey Mites}

In greenhouses, breeding sachets of Neoseiulus cucumeris AthiasHenriot have been developed to allow slow releases of predatory mites in the crop and thus reduce handling costs (Sampson, 1998). These rearing systems consist of predators, astigmatid mites as food and carrier material. They allow for a release of predators for periods up to four (sometimes even eight) weeks. In crops like roses or potted plants, that do not feature pollen, astigmatid prey mites do not establish on the plant, and where pests cannot be tolerated, predatory mite populations cannot build up on the crop and sachets need to be renewed regularly.

In potted plants, the spread of the predatory mites released from the breeding sachet is limited because plants are widely spaced; the majority of the predators remain on the plant, which received the sachet (Buitenhuis et al., 2010, 2014). To tackle these problems, strategies like using one (small) sachet per plant have been developed to provide each plant an open rearing system (Valentin, 2017) or predators and prey are blown over the crop 
TABLE 1 | Examples of facticious prey.

\begin{tabular}{l}
\hline Factitious prey \\
\hline Astigmatids: Carpoglyphus lactis L.; \\
Tyrophagus putrescentiae (Schrank) \\
Astigmatids: Aleuroglyphus ovatus \\
(Troupeau); Austroglycyphagus \\
lukoschusi (Fain); Blomia tropicalis; \\
Carpoglyphus lactis L.; Suidasia \\
medanensis (Oudemans); \\
Thyreophagus cracentiseta Barbosa \\
Cysts of Artemia spp.
\end{tabular}

Cysts of Artemia spp.

Anthocorids

Cysts of Artemia spp.

Coccinellids

Cysts of Artemia spp. Mirids

Cysts of Artemia spp.

Predatory mites

Sterilized eggs of Ephestia kuehniella Anthocorids Zeller

Sterilized eggs of Ephestia kuehniella Chrysopids Zeller

Sterilized eggs of Ephestia kuehniella Coccinellids Zeller

Sterilized eggs of Ephestia kuehniella Mirids Zeller

Sterilized eggs of Ephestia kuehniella Lygids Zeller

Sterilized eggs of Ephestia kuehniella Predatory mites Zeller
Orius naivashae (Poppius); Orius thripoborus (Hesse)

Amblydromalus limonicus Garman and McGregor; Amblyseius eharai Amitai and Swirski; Amblyseius tamatavensis Blommers; Amblyseius swirskii (Athias-Henriot); Gaeolaelaps aculeifer (Canestrini); Neoseiulus cucumeris (Oudemans)

\section{Source}

Bernardo et al., 2017; Bonte et al., 2017

Hoogerbrugge et al., 2008; Xia et al., 2012; Midthassel et al., 2013; Nguyen et al., 2013; Vangansbeke et al., 2014a; Barbosa and de Moraes, 2015; Ji et al., 2015; Ferrero et al., 2016; Massaro et al., 2016; Muñoz-Cárdenas et al., 2017; Rueda-Ramírez et al., 2018

Orius laevigatus (Fieber); Orius majusculus (Reuter); Arijs and De Clercq, 2001; De Clercq et al., 2005a; Orius naivashae (Poppius); Orius strigicollis (Poppius); Orius thripoborus (Hesse) Riudavets et al., 2006; Bonte and De Clercq, 2008; Bonte et al., 2012; Nishimori et al., 2016; Oveja et al., 2016; Sade et al., 2019

Harmonia axyridis (Pallas); Coleomegilla maculata (DeGeer)

Dicyphus errans (Wolff); Macrolophus pygmaeus Rambur; Nesidiocoris tenuis (Reuter)

Hongo and Obayashi, 1997; Riddick and Wu, 2015; Seko et al., 2019

Tavella and Arzone, 1996; Callebaut et al., 2004; Castañé et al., 2006; Riudavets et al., 2006; Vandekerkhove et al., 2006, 2009; Messelink et al., 2015; Hilgers et al., 2016; Oveja et al., 2016; Moerkens et al., 2017; Arvaniti et al., 2018; Brenard et al., 2018, 2019; Ghasemzadeh and Gharekhani, 2019; Owashi et al., 2020

Amblydromalus limonicus Garman and McGregor; Amblyseius swirskii (Athias-Henriot); Iphiseius degenerans (Berlese); Neoseiulus bicaudus (Wainstein); Neoseiulus cucumeris (Oudemans) Orius spp.; Orius albidipennis Reuter; Orius insidiosus (Say); Orius laevigatus (Fieber); Orius majusculus (Reuter); Orius naivashae (Poppius); Orius niger Wolff; Orius sauteri (Poppus); Orius strigicollis (Poppius); Orius thripoborus (Hesse); Orius tristicolor (White)

Chrysoperla carnea (Stephens); Chrysoperla externa (Hagen); Chrysoperla rufilabris (Burmeister)

Adalia bipunctata L.; Coleomegilla maculata DeGeer; Cryptolaemus montrouzieri Mulsant; Harmonia axyridis (Pallas)

Vantornhout et al., 2004; Oveja et al., 2012; Audenaert et al., 2013; Nguyen et al., 2014b, 2015; Vangansbeke et al., 2014b,c, 2016a,b; Leman and Messelink, 2015; Su et al., 2019

Salas-Aguilar and Ehler, 1977; Richards, 1992; Tommasini and Nicoli, 1993; Chyzik et al., 1995; Richards and Schmidt, 1995; Schmidt et al., 1995; Cocuzza et al., 1997; Arijs and De Clercq, 2001, 2004; Van Lenteren and Tommasini, 2003; De Clercq et al., 2005a; Riudavets et al., 2006; Ferkovich et al., 2007; Bonte and De Clercq, 2008; Yano et al., 2009; Vandekerkhove and De Clercq, 2010; Bonte et al., 2012, 2017; Oveja et al., 2012; Pumariño and Alomar, 2012, 2014; Nishimori et al., 2016; Bernardo et al., 2017; Sade et al., 2019

Zheng et al., 1993; Kathiar et al., 2015; Bezerra et al., 2017

Hongo and Obayashi, 1997; De Clercq et al., 2005b; Berkvens et al., 2007; Riddick, 2009; Attia et al., 2011; Maes et al., 2014; Riddick and Wu, 2015

Campyloneuropsis infumatus (Carvalho); Dicyphus Fauvel et al., 1987; Grenier et al., 1989; Constant et al., errans (Wolff); Dicyphus hesperus Knight; Dicyphus 1996; Tavella and Arzone, 1996; Gillespie and McGregor, tamaninii Wagner; Engytatus varians (Distant); Macrolophus basicornis (Stal); Macrolophus pygmaeus Rambur; Nesidiocoris tenuis (Reuter)

Geocoris varius (Uhler); Geocoris proteus Distant

Amblydromalus limonicus Garman and McGregor Amblyseius swirskii (Athias-Henriot); Euseius scutalis (Athias-Henriot); Iphiseius degenerans (Berlese); Neoseiulus barkeri (Hughes)
2000; Iriarte and Castañé, 2001; Sanchez et al., 2003, 2004; Callebaut et al., 2004; Castañé and Zapata, 2005; Messelink et al., 2005; Alomar et al., 2006; Castañé et al., 2006; Riudavets et al., 2006; Vandekerkhove et al., 2006, 2009; Oveja et al., 2012; Put et al., 2012; Mollá et al., 2014; Van Holstein and Messelink, 2014; Hilgers et al., 2016; Perdikis and Arvaniti, 2016; Moerkens et al., 2017; Arvaniti et al., 2018; Brenard et al., 2018; Bueno et al., 2018; Ghasemzadeh and Gharekhani, 2019; Owashi et al., 2020

Oida and Kadono, 2012; Igarashi and Nomura, 2013

Romeih et al., 2004; Vantornhout et al., 2004; Momen and El-Laithy, 2007; Audenaert et al., 2013; Nguyen et al., 2014a; Vangansbeke et al., 2014a,b,c; Leman and Messelink, 2015 
with purpose built automatized blowers. Supplying predatory mites with factitious (astigmatid) prey mites as food has recently gained popularity among growers. The following feeding mites could be used to improve the reproduction and survival of predatory mites: Tyrophagus putrescentiae (Schrank) (Pirayeshfar et al., 2020), Carpoglyphus lactis (L.) (Nguyen et al., 2013), Thyreophagus entomophagus (Laboulbene), Suidasia medanensis (Oudemans) (Sánchez et al., 2019), and Aleuroglyphus ovatus (Troupeau) (Xia et al., 2012; Ferrero et al., 2016; Rueda-Ramírez et al., 2018). However, very few trials have been performed at plant level (Hoogerbrugge et al., 2008; Vila et al., 2017; Pirayeshfar et al., 2020) and studies on the actual effect of these strategies on pest control are limited. Pirayeshfar et al. (2020) succeeded in increasing Amblyseius swirskii AthiasHenriot numbers on chrysanthemum plants by providing living T. putrescentiae per plant, but failed to do so using frozen T. putrescentiae. Pirayeshfar et al. (2020) suggested that the different diets used to rear the prey mites may have an influence on the population increase of the predatory mites. Nowadays, some growers disperse the astigmatid mites $C$. lactis or $T$. entomophagus to supplement the released predatory mites with food. Ferrero et al. (2016) developed a gel product protecting astigmatid mites' eggs when they are dispersed, and increasing their shell-life on the crops. This product resulted in high population levels of A. swirskii on cucumber plants and a better biological control of sweet potato whitefly than with the use of breeding sachets. Using astigmatid mites as food supplement has the advantage that they are relatively cheap (Ramakers and van Lieburg, 1982; Castagnoli, 1989). The main drawback of mass application of astigmatid mites lies in the fact that they can cause health issues for users including dermatitis, allergies and anaphylaxis (Iglesias-Souto et al., 2009; Fernández-Caldas et al., 2014; Liu and Zhang, 2017; Mullen and O'Connor, 2019; Pirayeshfar et al., 2020). Furthermore, Tyrophagus spp. can cause plant damage (Czaikowska et al., 1988; Buxton, 1989; Fischer, 1993; Fan and Zhang, 2007; Yasukawa et al., 2011).

Muñoz-Cárdenas et al. (2017) proposed another approach using astigmatid mites in combination with mulch layers to provide food to crop-inhabiting predatory mites. Prey mites were introduced in the litter to stimulate the predatory mite A. swirskii on aboveground plant parts. In cage experiments with rose plants this increased predatory mite numbers 4 -fold, as compared to control plants. Thrips control was increased and leaf- and flower damage was reduced as a result. It was shown that A. swirskii, which is usually considered to be a leaf-inhabiting species, actually moved between rose foliage and mulch to feed on the astigmatid mites. Similarly, Grosman et al. (2014) increased biocontrol of thrips and whiteflies with A. swirskii using mulch layers in different ornamental crops. Adding mulches with, for example bran, yeast or Biotop ${ }^{\circledR}$, waste product of the potato industry (Grosman and de Groot, 2011), organic matter (Settle et al., 1996; Neves Esteca et al., 2020), animal manure (Navarro-Campos et al., 2012) to boost fungi, decomposers and plankton feeders can increase predators' population levels. Despite promising results in small-scale experiments, this strategy has not been adopted by growers. This is probably due to the increased labor when mulching, and the fact that the system is often effective on the short term only. Grosman et al. (2014) found that this approach produced predators for up to 6 weeks, which is comparable to the longevity of breeding sachets. These methods carry also the risk that the predators switch from feeding on herbivores to soil organisms (apparent mutualism, Holt, 1977) as reported by Birkhofer et al. (2008), or, are out-competed by other soil predators, that also benefit from the substrate manipulation (Messelink and Van Holstein-Saj, 2007, 2011).

\section{Mediterranean Flour Moth Eggs}

To support establishment of predatory bugs, growers mainly use eggs of the Mediterranean flour moth E. kuehniella. The high nutritional value of E. kuehniella eggs ensures development, reproduction and survival of many arthropods (Table 1). In $M$. pygmaeus, higher reproduction rates were found when the mirids were fed on the moth eggs, as compared to whitefly pupae (Fauvel et al., 1987; Alomar et al., 2006). Sprinkling of E. kuehniella eggs on crop plants was the first supplemental food strategy widely adopted by growers on a large scale. They are typically used on the points where predatory bugs Orius spp. (sweet pepper) and mirid bugs M. pygmaeus, N. tenuis, and Tupiocoris cucurbitaceus (Spinola) (mainly tomato) are introduced (Put et al., 2012; Moerkens et al., 2017; Brenard et al., 2018).

The main factor limiting the use of E. kuehniella eggs is their cost, with prices of $400 \mathrm{EUR} / \mathrm{kg}$ (Nguyen et al., 2014a). They also need to be kept frozen. Furthermore, the eggs tend to dry out once applied on the crop, or when the relative humidity is too high, they become moldy on the leaves. Due to their cost, E. kuehniella eggs are not used to feed predatory mites. However, this food source was found to be suitable for oviposition of Iphiseius degenerans (Berlese) (Vantornhout et al., 2004), A. swirski and Amblydromalus limonicus Garman and McGregor (Nguyen et al., 2014a; Vangansbeke et al., 2014c), Gaeolaelaps aculeifer Canestrini and Stratiolaelaps scimitus (Womersley) (Navarro-Campos et al., 2016), as well as for the pest F. occidentalis. The performance of predatory mites on E. kuehniella eggs can vary (Vangansbeke et al., 2014c; Leman and Messelink, 2015) depending on egg storage conditions and ambient humidity in the crop. Liu and Zhang (2017) observed that immatures of A. limonicus exhibited difficulties to pierce the chorion of E. kuehniella eggs that hardened at low ambient humidity.

\section{Cysts of the Brine Shrimp}

Several cheaper options have been investigated to replace the use of Ephestia moth eggs in commercial production as well as in field applications (Table 1). Out of the options tested, the most promising substitute of flour moth eggs for feeding generalist predators was found to be dry cysts of the brine shrimp Artemia spp. Having been used widely as fish food, Artemia cysts have the advantage that they can be stored for years in dry form, and do not require freezing as required for E. kuehniella eggs (Arijs and De Clercq, 2001). They keep their nutritional value longer than E. kuehniella eggs when applied on crops (De Clercq et al., 2005a; Messelink et al., 2016; Moerkens et al., 2017), they do not become moldy on plants (Vandekerkhove et al., 2009) and 
are, depending on the quality, up to 30 times cheaper than flour moth eggs (Nguyen et al., 2014a). However, Artemia cysts vary substantially in nutritional quality, and the high quality product is roughly the same price as E. kuehniella eggs. When used at high densities, Artemia cysts can leave a "fishy smell" on the crop. Brine shrimp cysts have been tested as prey for several natural enemies for production purposes (Table 1).

In field crops, Hoogerbrugge et al. (2008) and Leman and Messelink (2015) found either no or poor establishment of $A$. swirskii when fed with a commercial strain of Artemia sp. cysts alone in a chrysanthemum crop. In contrast, Vantornhout et al. (2004), Nguyen et al. (2014a) and Vangansbeke et al. (2014c, 2016b) showed in laboratory studies complete development of, respectively, I. degenerans, A. swirskii and A. limonicus on a diet of decapsulated cysts of a non-commercial Artemia franciscana Kellogg strain. Vangansbeke et al. (2016a) succeeded in establishing A. swirskii on chrysanthemum and ivy plants using this Artemia strain, but not when using a commercial decapsulated Artemia cyst product. Inconsistent results between studies might be explained by the incomplete decapsulation of the cysts or their level of hydration (Castañé et al., 2006) and by the substantial variation in Artemia product quality. De Clercq et al. (2005a) showed differences of composition and nutritional quality between Artemia cysts of diverse origins, which can have an impact on the nutritional value as well (Bloemhard et al., 2018; Sade et al., 2019). Overall, Artemia cysts have become a valuable complement in biological control programs in greenhouse vegetable crops, as most tomato and sweet pepper growers release $M$. pygmaeus with this alternative food, either by itself or in combination with E. kuehniella.

The provision of brine schrimp cysts and Mediterranean flour moth eggs is now a common practice on introduction points of predatory bugs in vegetable crops. As astigmatid prey mites are concerned, only ornamental growers release them weekly or biweekly, but generally additionally to predatory mites. They tend to use them within their inundative release strategies of predatory mites instead of seeking for an early establishment of predators after a few release. Besides their use to stimulate predatory mites, astigmatid mites might also hold potential to support field populations of predatory bugs, as they were found to be a suitable food source for Orius spp. (El-Husseiniak and Sermann, 1992; Husseini et al., 1993; Nagai et al., 1998; Gomaa and Agamy, 2002; Yang et al., 2009; Bernardo et al., 2017; Bonte et al., 2017; Song et al., 2018). This application is still at an experimental stage at growers.

\section{BANKER PLANT SYSTEMS}

Supplementation of food resources and oviposition places for natural enemies can be done by providing secondary plants, so-called "banker plants" or "open rearing systems" (Bennison, 1992; Bennison and Corless, 1993). The principle of the banker plant system is the use of plants, usually different from the crop, to provide beneficials with alternative (non-pest) prey and/or plant-provided food resources. This method was developed for the introduction of parasitoid wasps to control aphids (Starý,
1969; Lyon, 1973) and whiteflies (Stacey, 1977). The banker plant method is often seen as a further development of the "Pest-in-first" method in greenhouses as the initial banker plant systems introduced additional crop plants carrying the target pest (Table 2) (Parr and Stacey, 1975; Stacey, 1977).

The advantages of using banker plants have been widely described. They aid survival, reproduction and development of naturally occurring or introduced natural enemies even in absence of pests (Pratt and Croft, 2000). When introducing beneficials, they can be released onto the banker plants where they find essential resources for survival and reproduction. Once the target pest appears, they then move from the banker plants into the crop. Successful banker plant systems allow for early season augmentation of beneficials and can replace "repeated inundative releases" (Hansen, 1983) thereby reducing costs (Huang et al., 2011). Furthermore, when using potted banker systems, these banker plants can be moved for "hot spot treatment" of pest colonies (Ramakers and Voet, 1995). When selecting banker plants, one should consider the natural enemies' affinity for the plant, as well as the plant's capacity to carry suitable alternative prey or other (food) resources (Jacobson and Croft, 1998; Goolsby and Ciomperlik, 1999). Nutritional, allelochemical and plant morphological traits (Price et al., 1980; Grevstad and Klepetka, 1992, Desneux and Ramirez-Romero, 2009) are taken into account when selecting candidate banker plant-prey combinations. It is known that morphological plant characteristics (e.g., toughness of leaves and stems, number of nectar glands, flowering period, number of flowers, plant pubescence, acarodomatia, trichomes) can be correlated with the dispersal, oviposition, developmental and reproductive success of arthropods (Walter and O’Dowd, 1992a,b; Pfannenstiel and Yeargan, 1998; Lucas and Brodeur, 1999, Lundgren et al., 2008; Parolin et al., 2012a). In addition, banker plants must be capable to survive temperatures and light conditions as the ones used in greenhouse production (Van der Linden, 1992).

Banker plant systems can be divided into two groups: (1) plants providing non-pest prey/host (2) plants producing nonprey food sources (pollen and nectar). Diverse publications provide complete inventories of the banker plant systems and their potential (Osborne et al., 2005; Frank, 2010; Huang et al., 2011; Ying et al., 2012; Miller et al., 2017; Miller, 2018; Payton Miller and Rebek, 2018). An overview of banker plant systems is given in Tables $\mathbf{2 - 4}$.

\section{Banker Plant Systems (Non-pest Prey)}

Most banker plant systems using alternative prey/hosts (Table 3) were designed to control aphids, such as Myzus persicae Sulzer on sweet peppers or Aphis gossypii Glover on cucumbers. Hansen (1983) first evaluated a banker plant system using broad bean infected with Megoura viciae Bucken, to rear Aphidoletes aphidimyza (Rondani). Other banker plant systems consist of sorghum, rye, barley or wheat seedlings infested with cereal aphids which are harmless to greenhouse crops, such as Rhopalosiphum padi Linnaeus, Sitobion avenae Fabricius, Metopolophium dirhodum (Walker), Melanaphis sacchari (Zehntner), or Schizaphis graminum (Rondani) (Kuo-Sell, 1987; Abe et al., 2011; Nagasaka et al., 2011; Yano et al., 2011). 
TABLE 2 | Examples of (pest prey) banker plant systems.

\begin{tabular}{|c|c|c|c|c|c|}
\hline $\begin{array}{l}\text { Banker plant } \\
\text { (common name) }\end{array}$ & $\begin{array}{l}\text { Banker plant (Latin } \\
\text { name) }\end{array}$ & Prey/host & $\begin{array}{l}\text { Category natural } \\
\text { enemy }\end{array}$ & Natural enemy & Source \\
\hline Borage & Borago officinalis L. & Myzus persicae (Sulzer) & Parasitoids & $\begin{array}{l}\text { Aphidius colemani } \\
\text { Viereck }\end{array}$ & Fujinuma et al., 2010 \\
\hline Bush bean & Phaseolus vulgaris L. & $\begin{array}{l}\text { Tetranychus urticae } \\
\text { Koch }\end{array}$ & Mites & $\begin{array}{l}\text { Phytoseiulus persimilis } \\
\text { Athias-Henriot }\end{array}$ & Matteoni, 2003 \\
\hline Castor bean & Ricinus communis L. & $\begin{array}{l}\text { Bemisia tabaci } \\
\text { (Gennadius) }\end{array}$ & Parasitoids & $\begin{array}{l}\text { Eretmocerus hayati } \\
\text { (Zolnerowich and } \\
\text { Rose); Encarsia sophia } \\
\text { (Girault and Dodd) }\end{array}$ & Kidane et al., 2018 \\
\hline Corn & Zea mays L. & $\begin{array}{l}\text { Tetranychus urticae } \\
\text { Koch }\end{array}$ & Mites & $\begin{array}{l}\text { Phytoseiulus persimilis } \\
\text { Athias-Henriot }\end{array}$ & $\begin{array}{l}\text { Miller et al., 2017; } \\
\text { Miller, } 2018\end{array}$ \\
\hline Kidney bean & Phaseolus vulgaris L. & $\begin{array}{l}\text { Tetranychus urticae } \\
\text { Koch }\end{array}$ & Mites & $\begin{array}{l}\text { Amblyseius fallacis } \\
\text { Garman }\end{array}$ & Lester et al., 2000 \\
\hline Laurustinus & Viburnum tinus L. & $\begin{array}{l}\text { Tetranychus urticae } \\
\text { Koch }\end{array}$ & Mites & $\begin{array}{l}\text { Neoseiulus californicus } \\
\text { (McGregor); } \\
\text { Phytoseiulus persimilis } \\
\text { Athias-Henriot }\end{array}$ & $\begin{array}{l}\text { Parolin et al., 2013; } \\
\text { Bresch et al., } 2015\end{array}$ \\
\hline Melon & Cucumis melo L. & $\begin{array}{l}\text { Bemisia tabaci } \\
\text { (Gennadius) }\end{array}$ & Parasitoids & $\begin{array}{l}\text { Encarsia sophia (Girault } \\
\text { and Dodd); } \\
\text { Eretmocerus spp.; } \\
\text { Eretmocerus hayati } \\
\text { (Zolnerowich and Rose) }\end{array}$ & $\begin{array}{l}\text { Goolsby and } \\
\text { Ciomperlik, 1999; } \\
\text { Pickett et al., 2004; } \\
\text { Kidane et al., } 2018\end{array}$ \\
\hline Pumpkin & $\begin{array}{l}\text { Cucurbita maxima } \\
\text { "Uchiki Kuri" }\end{array}$ & $\begin{array}{l}\text { Trialeurodes } \\
\text { vaporariorum } \\
\text { Westwood }\end{array}$ & Parasitoids & $\begin{array}{l}\text { Encarsia tricolor } \\
\text { Foërster }\end{array}$ & $\begin{array}{l}\text { Laurenz and Meyhöfer, } \\
2017\end{array}$ \\
\hline Rhododendron & $\begin{array}{l}\text { Rhododendron sp. } \\
\text { "Ana Kruschke" }\end{array}$ & $\begin{array}{l}\text { Oligonychus ilicis } \\
\text { (McGregor) and } \\
\text { Oligonychus ununguis } \\
\text { (Jacobi) }\end{array}$ & Mites & $\begin{array}{l}\text { Neoseiulus fallacis } \\
\text { (Garman) }\end{array}$ & Pratt and Croft, 2000 \\
\hline Riverbank grape & Vitis riparia (Michx.) & $\begin{array}{l}\text { Tetranychus urticae } \\
\text { Koch }\end{array}$ & Mites & $\begin{array}{l}\text { Neoseiulus californicus } \\
\text { (McGregor); } \\
\text { Phytoseiulus persimilis } \\
\text { Athias-Henriot }\end{array}$ & $\begin{array}{l}\text { Parolin et al., 2013; } \\
\text { Bresch et al., } 2015\end{array}$ \\
\hline Rose & Rosa sp. & Macrosiphum rosae L. & Parasitoids & Praon volucre Haliday & Maisonneuve, 2002 \\
\hline Swedes & $\begin{array}{l}\text { Brassicae napus } \\
\text { rapifera Metzg. }\end{array}$ & Myzus persicae (Sulzer) & Parasitoids & $\begin{array}{l}\text { Ephedrus cerasicola } \\
\text { Starý }\end{array}$ & $\begin{array}{l}\text { Hågvar and Hofsvang, } \\
1994\end{array}$ \\
\hline Sweet pepper & Capsicum annuum L. & Myzus persicae (Sulzer) & Parasitoids & $\begin{array}{l}\text { Ephedrus cerasicola } \\
\text { Starý }\end{array}$ & $\begin{array}{l}\text { Hofsvang and Hågvar, } \\
1979\end{array}$ \\
\hline Sweet pepper & Capsicum annuum L. & Aphids & Parasitoids & $\begin{array}{l}\text { Aphidius colemani } \\
\text { Viereck; Aphidius ervi } \\
\text { Haliday }\end{array}$ & Matteoni, 2003 \\
\hline Sweet pepper & Capsicum annuum L. & Aphids & Gall midges & $\begin{array}{l}\text { Aphidoletes aphidimyza } \\
\text { (Rondani) }\end{array}$ & Matteoni, 2003 \\
\hline Tobacco & Nicotiana tabacum L. & $\begin{array}{l}\text { Trialeurodes } \\
\text { vaporariorum } \\
\text { Westwood }\end{array}$ & Parasitoids & $\begin{array}{l}\text { Encarsia formosa } \\
\text { (Gahan) }\end{array}$ & Schmidt, 1996 \\
\hline Tomato & $\begin{array}{l}\text { Lycopersicon } \\
\text { esculentum Mill. }\end{array}$ & $\begin{array}{l}\text { Trialeurodes } \\
\text { vaporariorum } \\
\text { Westwood }\end{array}$ & Parasitoids & $\begin{array}{l}\text { Encarsia formosa } \\
\text { (Gahan) }\end{array}$ & $\begin{array}{l}\text { Parr and Stacey, 1975; } \\
\text { Stacey, 1977; Rumei, } \\
1991\end{array}$ \\
\hline Watermelon & $\begin{array}{l}\text { Citrullus lanatus } \\
\text { (Thunb.) }\end{array}$ & $\begin{array}{l}\text { Bemisia tabaci } \\
\text { (Gennadius) }\end{array}$ & Parasitoids & $\begin{array}{l}\text { Eretmocerus hayati } \\
\text { (Zolnerowich and Rose) }\end{array}$ & $\begin{array}{l}\text { Goolsby and } \\
\text { Ciomperlik, } 1999\end{array}$ \\
\hline
\end{tabular}

Parasitoids, such as Aphidius colemani Viereck, Aphidius ervi Haliday, and Aphidius matricariae Haliday, and, the predatory gall midge A. aphidimyza can reproduce on these banker plant systems and thus be pre-established once crop aphids appear (Table 3). Abe et al. (2011) succeeded in maintaining
A. aphidimyza for at least 3 months with such a system. Banker plant systems with non-pest prey used to be broadly implemented (Walters and Hardwick, 2000; Nagasaka and Oya, 2003; Yano, 2006). Some growers produce the banker plants themselves. However, a majority of growers are reluctant to adopt 
TABLE 3 | Examples of (non-pest prey) banker plant systems.

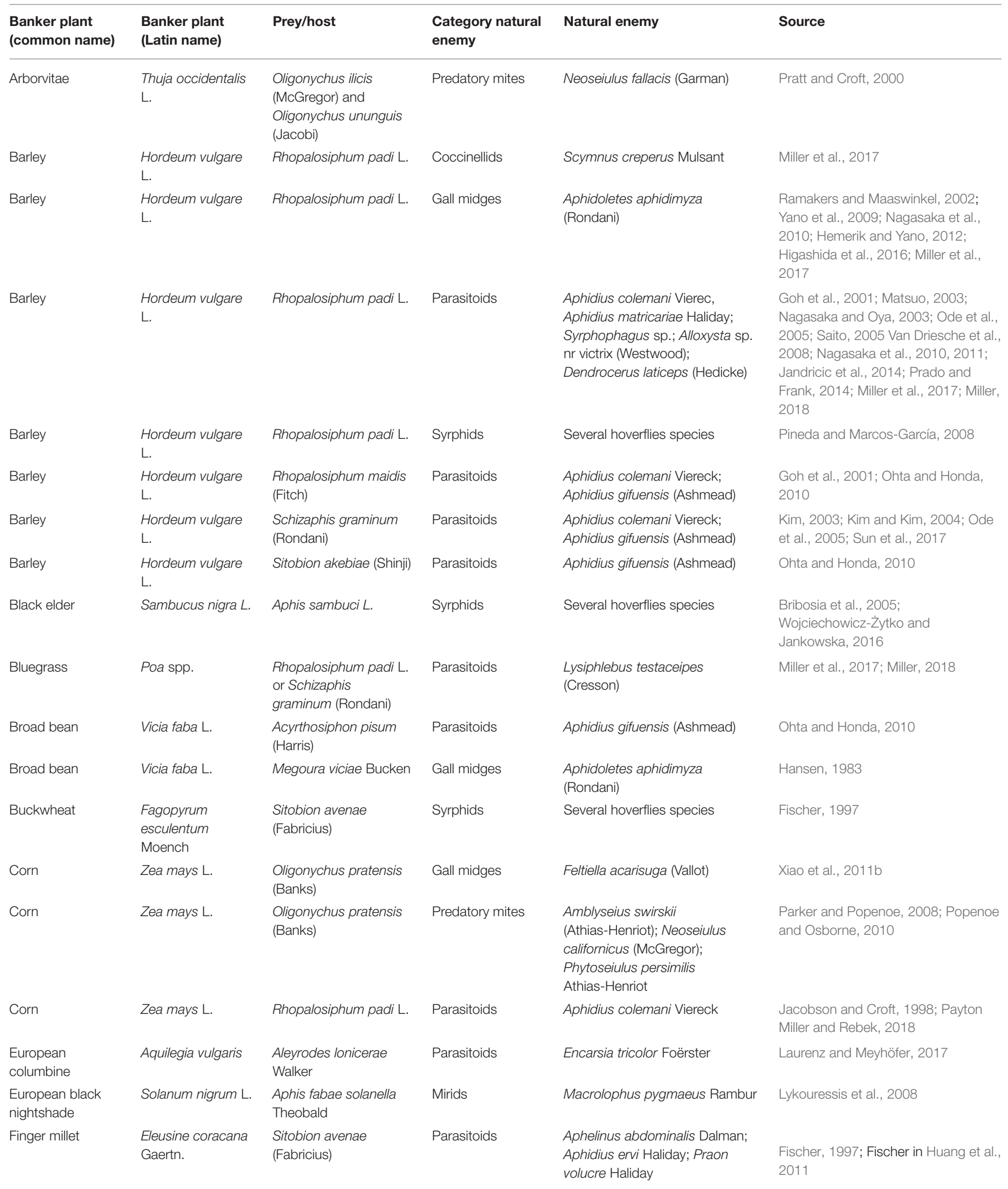


TABLE 3 | Continued

\begin{tabular}{|c|c|c|c|c|c|}
\hline $\begin{array}{l}\text { Banker plant } \\
\text { (common name) }\end{array}$ & $\begin{array}{l}\text { Banker plant } \\
\text { (Latin name) }\end{array}$ & Prey/host & $\begin{array}{l}\text { Category natural } \\
\text { enemy }\end{array}$ & Natural enemy & Source \\
\hline Finger millet & $\begin{array}{l}\text { Eleusine coracana } \\
\text { Gaertn. }\end{array}$ & Rhopalosiphum padi L. & Parasitoids & $\begin{array}{l}\text { Aphidius colemani Viereck; } \\
\text { Lysiphlebus testaceipes } \\
\text { (Cresson) }\end{array}$ & $\begin{array}{l}\text { Delgado, 1997; Fischer and Leger, } \\
\text { 1997; Schoen and Martin, 1997; } \\
\text { Vergniaud, 1997; Martin et al., 1998; } \\
\text { Schoen, 2000; Boll et al., 2001a,b }\end{array}$ \\
\hline Finger millet & $\begin{array}{l}\text { Eleusine coracana } \\
\text { Gaertn. }\end{array}$ & $\begin{array}{l}\text { Sitobion avenae } \\
\text { (Fabricius) }\end{array}$ & Syrphids & Episyrphus sp. & Fischer, 1997 \\
\hline Greater celandine & $\begin{array}{l}\text { Chelidonium } \\
\text { majus L. }\end{array}$ & Aleyrodes proletella L. & Parasitoids & Encarsia formosa Gahan & $\begin{array}{l}\text { Van der Linden and van der Staaij, } \\
2001\end{array}$ \\
\hline Kale & $\begin{array}{l}\text { Borecole oleracea } \\
\text { L. }\end{array}$ & Aleyrodes proletella L. & Parasitoids & Encarsia formosa Gahan & Laska and Zelenkova, 1988 \\
\hline Lucerne & Medicago sativa L. & $\begin{array}{l}\text { Acyrthosiphon pisum } \\
\text { (Harris) }\end{array}$ & Parasitoids & Aphidius ervi Haliday & Cameron et al., 1984 \\
\hline Melon & Cucumis melo L. & $\begin{array}{l}\text { Bemisia tabaci } \\
\text { (Gennadius) }\end{array}$ & Parasitoids & $\begin{array}{l}\text { Encarsia sophia (Girault and } \\
\text { Dodd); Eretmocerus spp.; } \\
\text { Eretmocerus hayati (Zolnerowich } \\
\text { and Rose) }\end{array}$ & $\begin{array}{l}\text { Goolsby and Ciomperlik, 1999; } \\
\text { Pickett et al., 2004; Kidane et al., } \\
2018\end{array}$ \\
\hline Nipplewort & $\begin{array}{l}\text { Lapsana } \\
\text { communis L. }\end{array}$ & Aleyrodes proletella L. & Parasitoids & Encarsia formosa Gahan & $\begin{array}{l}\text { Van der Linden and van der Staaij, } \\
2001\end{array}$ \\
\hline Oat & Avena sativa L. & $\begin{array}{l}\text { Metopolophium } \\
\text { dirhodum (Walker) }\end{array}$ & Gall midges & $\begin{array}{l}\text { Aphidoletes aphidimyza } \\
\text { (Rondani) }\end{array}$ & Götte and Sell, 2002 \\
\hline Oat & Avena sativa L. & $\begin{array}{l}\text { Rhopalosiphum padi L. } \\
\text { or Schizaphis } \\
\text { graminum (Rondani) }\end{array}$ & Parasitoids & $\begin{array}{l}\text { Aphelinus abdominalis Dalman; } \\
\text { Aphidius colemani Viereck }\end{array}$ & $\begin{array}{l}\text { Andorno and López, 2014; Miller } \\
\text { et al., 2017; Miller, } 2018\end{array}$ \\
\hline Papaya & Carica papaya L. & $\begin{array}{l}\text { Trialeurodes variabilis } \\
\text { (Quaintance) }\end{array}$ & Coccinellids & Delphastus pusillus (LeConte) & Osborne et al., 2005 \\
\hline Papaya & Carica papaya L. & $\begin{array}{l}\text { Trialeurodes variabilis } \\
\text { (Quaintance) }\end{array}$ & Parasitoids & $\begin{array}{l}\text { Encarsia transvena Timberlake; } \\
\text { Encarsia sophia (Girault and } \\
\text { Dodd) }\end{array}$ & $\begin{array}{l}\text { Osborne et al., 2005; Xiao et al., } \\
2011 a\end{array}$ \\
\hline Persian buttercup & $\begin{array}{l}\text { Ranunculus } \\
\text { asiaticus L. }\end{array}$ & $\begin{array}{l}\text { Phytomyza caulinaris } \\
\text { Hering }\end{array}$ & Parasitoids & $\begin{array}{l}\text { Dacnusa sibirica Telenga; } \\
\text { Diglyphus isaea Walker }\end{array}$ & Van der Linden, 1992 \\
\hline Potato & $\begin{array}{l}\text { Solanum } \\
\text { tuberosum L. }\end{array}$ & $\begin{array}{l}\text { Macrosiphum } \\
\text { euphorbiae (Thomas) }\end{array}$ & Parasitoids & Aphelinus abdominalis Dalman & Blümel and Hausdorf, 1996 \\
\hline Rhododendron & Rhododendron sp. & $\begin{array}{l}\text { Oligonychus ilicis } \\
\text { (McGregor) and } \\
\text { Oligonychus ununguis } \\
\text { (Jacobi) }\end{array}$ & Predatory mites & Neoseiulus fallacis (Garman) & Pratt and Croft, 2000 \\
\hline Rye & Secale cereale L. & Rhopalosiphum padi L. & Parasitoids & Aphidius colemani Viereck & $\begin{array}{l}\text { McClure, 2014; McClure and Frank, } \\
2015\end{array}$ \\
\hline Rye & Secale cereale L. & $\begin{array}{l}\text { Rhopalosiphum maidis } \\
\text { (Fitch) }\end{array}$ & Parasitoids & $\begin{array}{l}\text { Aphidius colemani Viereck; } \\
\text { Aphidius ervi Haliday }\end{array}$ & Matteoni, 2003 \\
\hline Rye & Secale cereale L. & $\begin{array}{l}\text { Rhopalosiphum maidis } \\
\text { (Fitch) }\end{array}$ & Gall midges & $\begin{array}{l}\text { Aphidoletes aphidimyza } \\
\text { (Rondani) }\end{array}$ & Matteoni, 2003 \\
\hline Ryegrass & $\begin{array}{l}\text { Lolium multiflorum } \\
\text { L. }\end{array}$ & Rhopalosiphum padi L. & Parasitoids & Aphidius colemani Viereck & Jacobson and Croft, 1998); \\
\hline Ryegrass & $\begin{array}{l}\text { Lolium multiflorum } \\
\text { L. }\end{array}$ & $\begin{array}{l}\text { Rhopalosiphum padi L. } \\
\text { or Schizaphis } \\
\text { graminum (Rondani) }\end{array}$ & Parasitoids & $\begin{array}{l}\text { Lysiphlebus testaceipes } \\
\text { (Cresson) }\end{array}$ & Miller et al., 2017; Miller, 2018 \\
\hline Savoy cabbage & $\begin{array}{l}\text { Brassica oleracea } \\
\text { L. }\end{array}$ & $\begin{array}{l}\text { Brevicoryne brassicae } \\
\text { L. }\end{array}$ & Parasitoids & Diaeretiella rapae Mclntosh & Freuler et al., 2001, 2003 \\
\hline Sorghum & $\begin{array}{l}\text { Sorghum bicolor } \\
\text { L. }\end{array}$ & Rhopalosiphum padi L. & Parasitoids & Aphidius colemani Viereck & Payton Miller and Rebek, 2018 \\
\hline Sorghum & $\begin{array}{l}\text { Sorghum bicolor } \\
\text { L. }\end{array}$ & $\begin{array}{l}\text { Rhopalosiphum maidis } \\
\text { (Fitch) }\end{array}$ & Parasitoids & Diaeretiella rapae Mclntosh & Ceballos et al., 2011 \\
\hline Sorghum & $\begin{array}{l}\text { Sorghum bicolor } \\
\text { L. }\end{array}$ & $\begin{array}{l}\text { Schizaphis graminum } \\
\text { (Rondani) }\end{array}$ & Parasitoids & $\begin{array}{l}\text { Lysiphlebus testaceipes } \\
\text { (Cresson) }\end{array}$ & $\begin{array}{l}\text { Rodrigues and Bueno, 2001; Miller } \\
\text { et al., 2017; Miller, } 2018\end{array}$ \\
\hline
\end{tabular}


TABLE 3 | Continued

\begin{tabular}{|c|c|c|c|c|c|}
\hline $\begin{array}{l}\text { Banker plant } \\
\text { (common name) }\end{array}$ & $\begin{array}{l}\text { Banker plant } \\
\text { (Latin name) }\end{array}$ & Prey/host & $\begin{array}{l}\text { Category natural } \\
\text { enemy }\end{array}$ & Natural enemy & Source \\
\hline Sorghum & $\begin{array}{l}\text { Sorghum bicolor } \\
\text { L. }\end{array}$ & $\begin{array}{l}\text { Melanaphis sacchari } \\
\text { (Zehntner) }\end{array}$ & Gall midges & $\begin{array}{l}\text { Aphidoletes aphidimyza } \\
\text { (Rondani) }\end{array}$ & $\begin{array}{l}\text { Abe et al., 2011; Yano et al., 2011; } \\
\text { Higashida et al., } 2017\end{array}$ \\
\hline Switchgrass & $\begin{array}{l}\text { Panicum virgatum } \\
\text { L. }\end{array}$ & Rhopalosiphum padi L. & Parasitoids & Aphidius colemani Viereck & Payton Miller and Rebek, 2018 \\
\hline Triticale & $\begin{array}{l}\text { Triticosecale } \\
\text { rimpaui Wittm. }\end{array}$ & $\begin{array}{l}\text { Sitobion avenae } \\
\text { (Fabricius) }\end{array}$ & Parasitoids & Aphidius ervi Haliday & Jansson in Huang et al., 2011 \\
\hline Triticale & Triticosecale sp. & $\begin{array}{l}\text { Metopolophium } \\
\text { dirhodum (Walker) }\end{array}$ & Gall midges & $\begin{array}{l}\text { Aphidoletes aphidimyza } \\
\text { (Rondani) }\end{array}$ & Götte and Sell, 2002 \\
\hline Turnip & Brassica rapa L. & $\begin{array}{l}\text { Brevicoryne brassicae } \\
\text { L. }\end{array}$ & Parasitoids & Diaeretiella rapae Mclntosh & Freuler et al., 2001, 2003 \\
\hline Wheat & $\begin{array}{l}\text { Triticum aestivum } \\
\text { L. }\end{array}$ & $\begin{array}{l}\text { Diuraphis noxia } \\
\text { (Mordvilko) }\end{array}$ & Parasitoids & Aphidius matricariae Haliday & Miller and Gerth, 1994 \\
\hline Wheat & $\begin{array}{l}\text { Triticum aestivum } \\
\text { L. }\end{array}$ & Rhopalosiphum padi L. & Parasitoids & $\begin{array}{l}\text { Alloxysta sp. nr victrix } \\
\text { Westwood); Aphidius colemani } \\
\text { Viereck; Dendrocerus laticeps } \\
\text { (Hedicke); Aphidius matricariae } \\
\text { Haliday; Syrphophagus sp. }\end{array}$ & $\begin{array}{l}\text { Bennison, 1992; Lamparter, 1992; } \\
\text { Albert, 1995; Conte, 1998; Jacobson } \\
\text { and Croft, 1998; Van Schelt, 1999; } \\
\text { Nagasaka and Oya, 2003; Saito, } \\
2005 \text { Nagasaka et al., 2010, 2011; } \\
\text { Jandricic et al., 2014; McClure, 2014; } \\
\text { McClure and Frank, 2015; Miller } \\
\text { et al., 2017; Miller, 2018; Payton } \\
\text { Miller and Rebek, } 2018\end{array}$ \\
\hline Wheat & $\begin{array}{l}\text { Triticum aestivum } \\
\mathrm{L} .\end{array}$ & Rhopalosiphum padi L. & Coccinellids & Scymnus creperus Mulsant & Miller et al., 2017 \\
\hline Wheat & $\begin{array}{l}\text { Triticum aestivum } \\
\text { L. }\end{array}$ & Rhopalosiphum padi L. & Gall midges & $\begin{array}{l}\text { Aphidoletes aphidimyza } \\
\text { (Rondani) }\end{array}$ & $\begin{array}{l}\text { Bennison, 1992; Bennison and } \\
\text { Corless, 1993; Albert, 1995; Miller } \\
\text { et al., } 2017\end{array}$ \\
\hline Wheat & $\begin{array}{l}\text { Triticum aestivum } \\
\mathrm{L} .\end{array}$ & $\begin{array}{l}\text { Schizaphis graminum } \\
\text { (Rondani) }\end{array}$ & Parasitoids & $\begin{array}{l}\text { Aphidius gifuensis (Ashmead); } \\
\text { Aphidius colemani Viereck; } \\
\text { Lysiphlebus testaceipes } \\
\text { (Cresson) }\end{array}$ & $\begin{array}{l}\text { Starý, 1993; Miller et al., 2017; Sun } \\
\text { et al., 2017; Miller, } 2018\end{array}$ \\
\hline Wheat & $\begin{array}{l}\text { Triticum aestivum } \\
\text { L. }\end{array}$ & $\begin{array}{l}\text { Sitobion avenae } \\
\text { (Fabricius) }\end{array}$ & Parasitoids & $\begin{array}{l}\text { Aphidius ervi Haliday; Aphidius } \\
\text { gifuensis (Ashmead); Aphelinus } \\
\text { asychis Walker }\end{array}$ & $\begin{array}{l}\text { Van Schelt, 1999; Wang et al., 2016; } \\
\text { Miller et al., 2017; Miller, 2018; Sun } \\
\text { and Song, } 2019\end{array}$ \\
\hline Wheat & $\begin{array}{l}\text { Triticum aestivum } \\
\text { L. }\end{array}$ & $\begin{array}{l}\text { Sitobion avenae } \\
\text { (Fabricius) }\end{array}$ & Syrphids & Episyrphus balteatus DeGeer & Ankersmit et al., 1986 \\
\hline
\end{tabular}

the system, due to inconsistent efficacy, labor (handling and maintenance), sink effects, and/or issues with hyperparasitoids (Jacobson and Croft, 1998; Van Driesche et al., 2008; McClure and Frank, 2015; Payton Miller and Rebek, 2018). Furthermore, the parasitoid species reared on banker plant systems are not necessarily efficient against all occurring target pest species, such as the potato aphid, Macrosiphum euphorbiae (Thomas), and the foxglove aphid, Aulacorthum solani (Kaltenbach) (Van Driesche et al., 2008; Nagasaka et al., 2010; Prado et al., 2015). Development of parasitoid wasps (Jandricic et al., 2014) on the banker plant systems may be insufficient due to the provided aphids being of insufficient size. This can lead to a reduction of survival and male biased sex ratio of the parasitoids (Hoddle et al., 1998; Chau and Mackauer, 2001; Henry et al., 2005). Gall midges produced on aphid species of poor nutritional value can also suffer in terms of size and fecundity (Kuo-Sell, 1989). Natural enemies may be reluctant to switch from aphids on the banker plant to the crop aphids (Lester et al., 2000; Coyle et al.,
2011) which can hamper the establishment of beneficials on the crop. This can be due to an acquired adaptation to the banker plant aphid through associative learning processes (Hoddle et al., 1998, Keasar et al., 2001, Ode et al., 2005, Prado and Frank, 2014). For all these reasons, the use of non-pest prey banker plant systems is relatively limited, relative to other methods supporting preventative establishment.

\section{Banker Plant Systems (Nectar and Pollen)}

Natural enemies can also be boosted by banker plants providing pollen and nectar (Table 4). The use of castor beans as banker plants has been based on this principle, as it provides a copious and steady supply of pollen and extra-floral nectar, making it a suitable host plant for generalist phytoseiid predatory mites, such as I. degenerans and Euseius spp. (Van Rijn and Tanigoshi, 1999b). Castor bean bankers hosting about 2000 predatory mites have been used by growers allowing growers to move the plants to crop spots where pests were detected or where predatory mites 
TABLE 4 | Examples of (nectar-pollen) banker plant systems.

\begin{tabular}{|c|c|c|c|c|}
\hline $\begin{array}{l}\text { Banker plant } \\
\text { (common name) }\end{array}$ & Banker plant (Latin name) & $\begin{array}{l}\text { Category natural } \\
\text { enemy }\end{array}$ & Natural enemy & Source \\
\hline African marigold & Tagetes erecta L. & Anthocorids & Orius insidiosus say & Bueno et al., 2009 \\
\hline Basil & Ocimum basilicum L. & Anthocorids & Orius spp. & Cano et al., 2012 \\
\hline Bishop's weed & Ammi majus L. & Syrphids & $\begin{array}{l}\text { Episyrphus balteatus (De } \\
\text { Geer) }\end{array}$ & Wäckers and van Rijn, 2012 \\
\hline Buckweat & Fagopyrum esculentum L. & Chrysopids & $\begin{array}{l}\text { Chrysoperla carnea } \\
\text { (Stephens) }\end{array}$ & Wäckers and van Rijn, 2012 \\
\hline Buckweat & Fagopyrum esculentum L. & Syrphids & Several hoverflies species & $\begin{array}{l}\text { Colley and Luna, 2000; Wäckers and } \\
\text { van Rijn, } 2012\end{array}$ \\
\hline Borage & Borago officinalis L. & Chrysopids & $\begin{array}{l}\text { Chrysoperla carnea } \\
\text { (Stephens) }\end{array}$ & Wäckers and van Rijn, 2012 \\
\hline Chamomile & Matricariae camomilla L. & Chrysopids & $\begin{array}{l}\text { Chrysoperla carnea } \\
\text { (Stephens) }\end{array}$ & Wäckers and van Rijn, 2012 \\
\hline Chamomile & Matricariae camomilla L. & Syrphids & $\begin{array}{l}\text { Episyrphus balteatus (De } \\
\text { Geer) }\end{array}$ & Wäckers and van Rijn, 2012 \\
\hline Chenille bush & Acalypha hispida Burm. f. & Anthocorids & Orius laevigatus (Fieber) & Armando and Yates, 2011 \\
\hline Chrysanthemum & Chrysanthemum segetum L. & Chrysopids & $\begin{array}{l}\text { Chrysoperla carnea } \\
\text { (Stephens) }\end{array}$ & Wäckers and van Rijn, 2012 \\
\hline Corn flower & Centaurea cyanus L. & Chrysopids & $\begin{array}{l}\text { Chrysoperla carnea } \\
\text { (Stephens) }\end{array}$ & Wäckers and van Rijn, 2012 \\
\hline Corn flower & Centaurea cyanus L. & Syrphids & $\begin{array}{l}\text { Episyrphus balteatus (De } \\
\text { Geer) }\end{array}$ & Wäckers and van Rijn, 2012 \\
\hline False yellowhead & Dittrichia (= Inula) viscosa L. & Mirids & $\begin{array}{l}\text { Macrolophus melanotoma } \\
\text { Costa; Macrolophus } \\
\text { pygmaeus Rambur; } \\
\text { Nesidiocoris tenuis (Reuter) }\end{array}$ & $\begin{array}{l}\text { Vila, 2004; Perdikis et al., 2007; Cano } \\
\text { et al., } 2012\end{array}$ \\
\hline Feverfew & Tanacetum parthenium L. & Anthocorids & Orius insidiosus Say & Waite, 2012; Waite et al., 2014 \\
\hline Field Marigold & Calendula arvensis L. & Mirids & Nesidiocoris tenuis (Reuter) & Vila, 2004 \\
\hline Floss flower & Ageratum mexicanum Sims & Predatory mites & $\begin{array}{l}\text { Several predatory mite } \\
\text { species }\end{array}$ & Huang et al., 2011 \\
\hline French marigold & Tagetes patula L. & Anthocorids & Orius spp. & Imura and Kamikawa, 2012 \\
\hline Geranium & Geranium sp. & Mirids & Nesidiocoris tenuis (Reuter) & Vila, 2004; Cano et al., 2012 \\
\hline Gerbera daisy & $\begin{array}{l}\text { Gerbera jamesonii L. } \\
\text { "Festival" }\end{array}$ & Anthocorids & Orius insidiosus Say & Waite, 2012, Waite et al., 2014 \\
\hline Golden Crownbeard & $\begin{array}{l}\text { Verbesina encelioides Benth } \\
\text { and Hook }\end{array}$ & Anthocorids & Orius laevigatus (Fieber) & Armando and Yates, 2011 \\
\hline
\end{tabular}


TABLE 4 | Continued

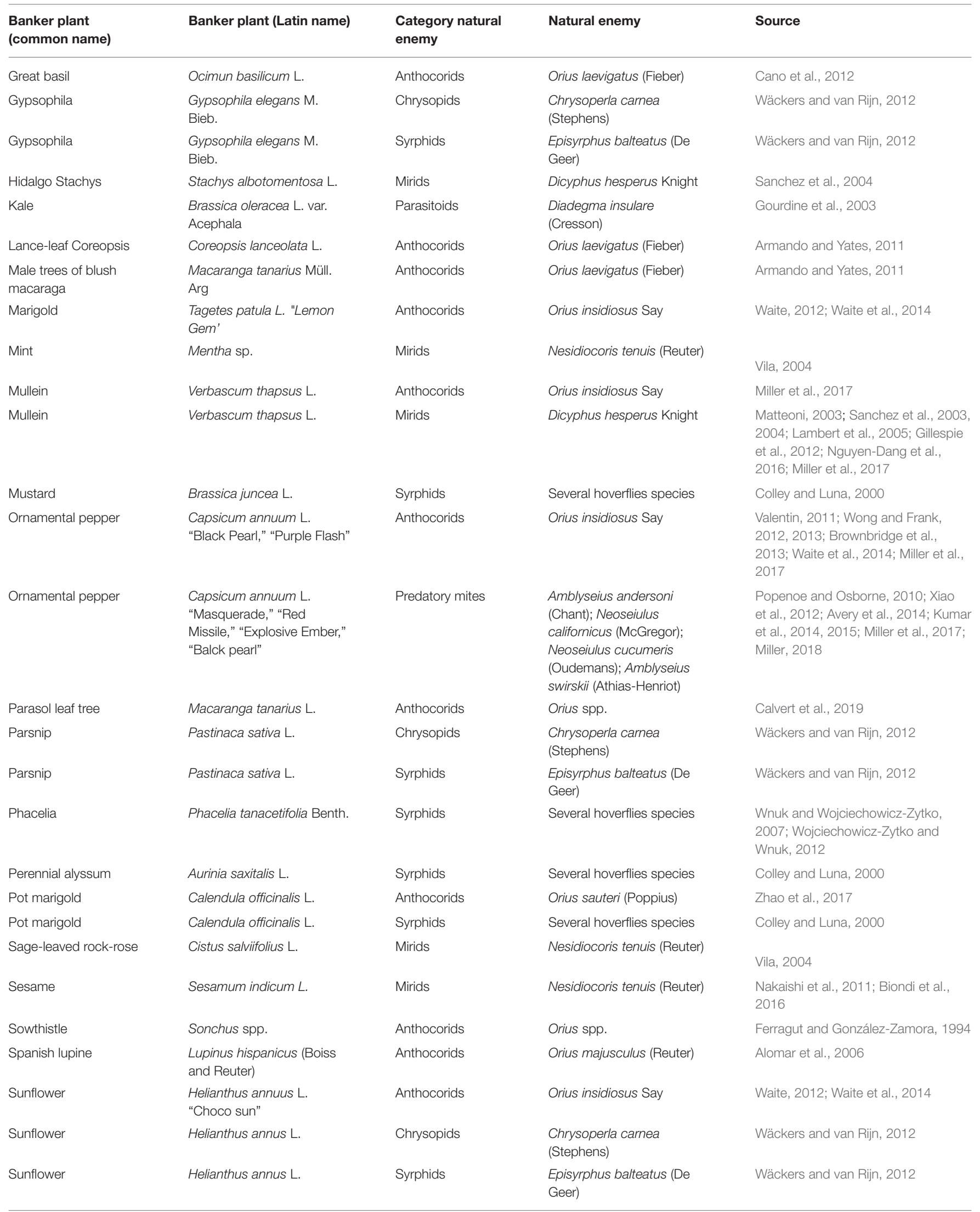


TABLE 4 | Continued

\begin{tabular}{|c|c|c|c|c|}
\hline $\begin{array}{l}\text { Banker plant } \\
\text { (common name) }\end{array}$ & Banker plant (Latin name) & $\begin{array}{l}\text { Category natural } \\
\text { enemy }\end{array}$ & Natural enemy & Source \\
\hline Sweet alyssum & Lobularia maritima (L.) Desv. & Anthocorids & $\begin{array}{l}\text { Orius spp.; Orius laevigatus } \\
\text { (Fieber); Orius majusculus } \\
\text { (Reuter) }\end{array}$ & $\begin{array}{l}\text { Picó and Retana, 2000; Alomar et al., } \\
\text { 2008; Bennison et al., 2011; Hogg } \\
\text { et al., 2011; Pumariño and Alomar, } \\
\text { 2012, } 2014\end{array}$ \\
\hline Sweet alyssum & Lobularia maritima (L.) Desv. & Parasitoids & $\begin{array}{l}\text { Dolichogenidea tasmanica } \\
\text { (Cameron) }\end{array}$ & Berndt and Wratten, 2005 \\
\hline Sweet alyssum & Lobularia maritima (L.) Desv. & Syrphids & $\begin{array}{l}\text { Several hoverflies species, } \\
\text { Eupeodes fumipennis } \\
\text { (Thomson) }\end{array}$ & $\begin{array}{l}\text { Colley and Luna, 2000; Pineda and } \\
\text { Marcos-García, 2008; Hogg et al., } \\
2011\end{array}$ \\
\hline Sweet alyssum & Lobularia maritima (L.) Desv. & Parasitoids & $\begin{array}{l}\text { Several parasitoids, Cotesia } \\
\text { marginiventris (Cresson); } \\
\text { Diadegma insulare } \\
\text { (Cresson); Trissolcus spp.; } \\
\text { Gyron obesum Masner }\end{array}$ & $\begin{array}{l}\text { Johanowicz and Mitchell, 2000; } \\
\text { Berndt and Wratten, 2005; Begum } \\
\text { et al., 2006; Pease and Zalom, } 2010\end{array}$ \\
\hline Sweet pepper & Capsicum annuum L. & Anthocorids & Orius laevigatus (Fieber) & $\begin{array}{l}\text { Van den Meiracker and Ramakers, } \\
1991\end{array}$ \\
\hline Tamarillo & $\begin{array}{l}\text { Cyphomandra betacea } \\
\text { (Cav.) Sendtn. }\end{array}$ & Mirids & $\begin{array}{l}\text { Macrolophus pygmaeus } \\
\text { Rambur }\end{array}$ & Fischer and Terrettaz, 2003 \\
\hline Tobacco & Nicotiana tabacum L. & Mirids & $\begin{array}{l}\text { Dicyphus hesperus Knight; } \\
\text { Macrolophus pygmaeus } \\
\text { Rambur }\end{array}$ & $\begin{array}{l}\text { Arnó et al., 2000; Ridray et al., 2001; } \\
\text { Fischer, 2003; Fischer and Terrettaz, } \\
\text { 2003; Schoen, 2003; Sanchez et al., } \\
\text { 2004; Bresch et al., } 2014\end{array}$ \\
\hline Tree marigold & Tithonia diversifolia (Hemsl.) & Anthocorids & Orius laevigatus (Fieber) & Armando and Yates, 2011 \\
\hline Vetch & Vicia sativa L. & Anthocorids & Orius majusculus (Reuter) & Alomar et al., 2006 \\
\hline Vetch & Vicia sativa L. & Parasitoids & Several species & Wäckers and van Rijn, 2012 \\
\hline Vetch & Vicia sativa L. & Syrphids & $\begin{array}{l}\text { Episyrphus balteatus (De } \\
\text { Geer) }\end{array}$ & Wäckers and van Rijn, 2012 \\
\hline White rocket & Diplotaxis erucoides L. & Anthocorids & Orius spp. & Ferragut and González-Zamora, 1994 \\
\hline Wild carrot & Daucus carota L. & Parasitoids & $\begin{array}{l}\text { Diadegma insulare } \\
\text { (Cresson) }\end{array}$ & $\begin{array}{l}\text { Idris and Grafius, 1995, 1996; } \\
\text { Johanowicz and Mitchell, } 2000\end{array}$ \\
\hline Wild carrot & Daucus carota L. & Chrysopids & $\begin{array}{l}\text { Chrysoperla carnea } \\
\text { (Stephens) }\end{array}$ & Wäckers and van Rijn, 2012 \\
\hline Wild mustard & Brassica kaber L. & Parasitoids & $\begin{array}{l}\text { Diadegma insulare } \\
\text { (Cresson) }\end{array}$ & $\begin{array}{l}\text { Idris and Grafius, 1995, 1996; } \\
\text { Johanowicz and Mitchell, } 2000\end{array}$ \\
\hline Yellow rocket & Barbarea vulgaris R. Br. & Parasitoids & $\begin{array}{l}\text { Diadegma insulare } \\
\text { (Cresson) }\end{array}$ & Idris and Grafius, 1995, 1996 \\
\hline
\end{tabular}

were scarce (Ramakers and Voet, 1995). However, this banker plant requires a lot of maintenance due to its rapid growth and the predatory mites do not always move into the crop. Additionally, castor bean can become a source of certain pests. The usefulness of castor bean plants was also limited in sweet pepper crops, as pepper produces pollen and floral nectar. Only a limited number of ornamental growers is still using castor bean plants. Many banker plant systems were developed to maintain predatory bugs, especially the anthocorid Orius spp., primarily used for the control of thrips. Establishing this predator requires prey, and a range of plant derived food, including pollen (Kiman and Yeargan, 1985; Richards and Schmidt, 1996; Corey et al., 1998), nectar (Yokoyama, 1978), and plant sap (Kiman and Yeargan, 1985; Richards and Schmidt, 1996; Lundgren et al., 2008). In addition, the plant structures need to be acceptable as oviposition substrate (Lundgren et al., 2008). The predator establishes easily in sweet pepper crops where it utilizes the floral resources of the pepper plants. However, most ornamental crops lack these resources. This hampers establishment of beneficials as well as the short crop cycle of many ornamentals. As repeated introductions of Orius spp. are too onerous and expensive for growers, a range of banker plant systems have been designed to support establishment of the predator. Several studies have used ornamental peppers "Black pearl" or "Purple Flash" and the perennial Sweet Alyssum (Valentin, 2011; Wong and Frank, 2013). The use of Sweet Alyssum with its long lasting flowering period results not only in higher densities of Orius spp. (Picó and Retana, 2000; Alomar et al., 2008; Bennison et al., 2011; Hogg et al., 2011; Pumariño and Alomar, 2014), but also benefits hoverflies, predatory Heteroptera (Pease and Zalom, 2010) and several parasitoids (Johanowicz and Mitchell, 2000; Berndt and Wratten, 2005; Begum et al., 2006). However, the adoption of this method has been limited due to the fact that Sweet Alyssum is also exploited by pollen-feeding pest species, such as thrips. Several banker plant systems have also been designed to attract and sustain reproductive populations of predatory mirids. These include tobacco plants for M. pygmaeus, mullen for Dicyphus hesperus Knight and sesame for N. tenuis (Table 4). Fischer 
and Terrettaz (2003) managed even to successfully overwinter M. caliginosus on tobacco and tamarillo as banker plants, thus allowing the establishment of the predatory bug into the new tomato crops the next spring. Other examples of banker plant systems maintaining predatory bugs are summarized in Table 4 . Addition of factitious prey on banker plants, as discussed earlier, is often suggested to increase survival, longevity and fecundity of the predatory bugs (Pumariño and Alomar, 2012, 2014).

The complexity of banker plant systems in greenhouse crops limited their adoption. Since the last decade, more straightforward methods have been developed to support the establishment and retention of beneficials in greenhouse. However, some sweet pepper growers still use them against aphids before the appearance of hyperparasitoids and there is an increased interest for banker plants to maintain predatory bugs in ornamental crops. Few attempts were made to use cover crops in or next to greenhouses and to grow combined crops, alternating rows of tomato, sweet pepper and egg plants in one greenhouse (Janmaat et al., 2014) to benefit from the vegetational diversity (Letourneau, 1983, 1990). Despite good technical results, these strategies failed in practice because of the complexity of their management. In open fields, we recently see an increased interest for the use of banker plant systems.

\section{POLLEN}

Providing pollen as a protein rich food in crops is another approach to boost establishment of pollen-feeding natural enemies, especially predatory mites. Pollen has been used extensively to support populations of generalist predatory mites (McMurtry and Scriven, 1966; Kennett et al., 1979; Van Rijn and Sabelis, 1990, 1993; Van Rijn and Tanigoshi, 1999a; Messelink et al., 2009; Nomikou et al., 2010; Hoogerbrugge et al., 2011; Maoz et al., 2014; Ranabhat et al., 2014, Vangansbeke et al., 2016a).

In greenhouse crops, bee-collected pollen has been tested in a number of studies, either as dry pellets or in suspension (Ramakers, 1995; Kolokytha et al., 2011; Goleva and Zebitz, 2013; Montserrat et al., 2013; Duarte et al., 2015). However, as the grains absorb water and become moldy, bee pollen was judged inappropriate by growers for crop applications (Ramakers, 1995). Attempts of using pollen providing banker plant systems, like castor beans (Ramakers and Voet, 1995; Van Rijn and Tanigoshi, 1999b), also failed, for reasons described previously. Pollen started to be used on a large scale by growers in July 2013, when commercial supplements based on narrowleaf cattail pollen were made available for crops where pollen sources are lacking (Pijnakker et al., 2014). This allowed preventative establishment of predatory mites in crops like cucumbers (which are parthenocarp and do not produce pollen), as well as ornamentals where no pests are tolerated.

Pollen can provide proteins, free amino acids, lipids, and phytosterols, nitrogen, carbohydrates, vitamins, and other inorganic minerals for many arthropods (Goss, 1968; Standifer et al., 1968; Stanley and Linskens, 1974; Rabie et al., 1983; Day et al., 1990; Roulston and Cane, 2000; Patt et al., 2003; Somerville and Nicol, 2006; Li et al., 2007; You et al., 2007; Campos et al., 2008; Lundgren, 2009). Pollen supports development, survival, and longevity of a range of natural enemies (Fauvel, 1974; Overmeer, 1985; Wäckers and van Rijn, 2005). Many studies (Table 5) show that several natural enemies are capable of reproducing and developing solely on pollen or in combination with other plant material in the absence of prey (Cocuzza et al., 1997; Beckman and Hurd, 2003; Berkvens et al., 2007; Carrillo et al., 2010). Among many studies on predatory mites, Onzo et al. (2005) showed increased survival and longevity of predatory mites when corn pollen was supplemented to the prey diet. Cloutier and Johnson (1993) and Buitenhuis et al. (2014) suggested that pollen feeding can benefit juvenile stages of predatory mites, since it is more difficult for them to attack thrips larvae, which usually show aggressive defensive behavior (Bakker and Sabelis, 1989). The nutritional value of the pollen depends on the pollen type (Todd and Bretherick, 1942; Saito and Mori, 1975; Van Rijn and Tanigoshi, 1999a; Goleva and Zebitz, 2013) and can differ between pollen consumers (Van Rijn and Tanigoshi, 1999a; Delisle et al., 2015a,b). Lundgren and Wiedenmann (2004) demonstrated that pollen quality can also vary within a given plant species. Van Rijn and Tanigoshi (1999a) showed the benefits of feeding on different pollen for predatory mites in the absence of prey. Pollen of Betulaceae, Euphorbiaceae, Leguminosae, Rosaceae, and Typhaceae seem, in general, to be suitable food sources for predatory mites (Table 5). The variations in nutritional value of pollen can be partly explained by the differences in the content of amino acids and lipids of pollen (Stanley and Linskens, 1974, Wäckers, 2005; Goleva and Zebitz, 2013). Also, pollen may contain secondary metabolites, that can reduce their suitability as food sources for arthropods (Rivest and Forrest, 2020); some types of pollen can even be toxic (Ranabhat et al., 2014; Goleva et al., 2015; Rivest and Forrest, 2020). In addition to variation in pollen nutrient composition, differences exist between natural enemies in their utilization of pollen from different plant species (McMurtry and Scriven, 1964; Van Rijn and Tanigoshi, 1999a; Adar et al., 2012). Part of this variation can be explained by the degree in which the phytoseiids have adapted to pollen feeding. While some predatory mites are specialized pollen feeders; others use it to complement their diet, while some specialist predators like Phytoseiulus do not consume pollen (McMurtry and Croft, 1997). Van Rijn and Tanigoshi (1999a) showed that $I$. degenerans could develop and reproduce on Betulaceae pollens whereas N. cucumeris failed to do so. Both predatory species did not perform on pollen from the conifer Pinopsida, but reproduced well on common cattail pollen. Goleva and Zebitz (2013) suggested that the morphology of the different pollens and their odor (Dobson and Bergström, 2000) are likely to influence their acceptance as food by a predator. Among insects, the coccinellids Coleomegilla maculata (DeGeer) and Harmonia axyridis (Pallas) use pollen as a supplemental food, allowing the ladybugs to survive during prey scarcity (Smith, 1960a,b; Koch, 2003; Lundgren and Wiedenmann, 2004; Lundgren et al., 2005; Michaud and Grant, 2005; Berkvens et al., 2007; Hodek and Honěk, 2013). The predatory bug Orius spp. has been frequently shown to be able to reproduce and develop on a sole diet of specific pollen (Fauvel, 1974; Naranjo and Gibson, 
TABLE 5 | Examples of suitable pollen types.

\begin{tabular}{|c|c|c|c|c|}
\hline $\begin{array}{l}\text { Plant (common } \\
\text { name) }\end{array}$ & Plant (Latin name) & $\begin{array}{l}\text { Category natural } \\
\text { enemy }\end{array}$ & Natural enemy & Source \\
\hline African oil palm & Elaeis guinensis Jacq. & Predatory mites & $\begin{array}{l}\text { Amblyseius aerialis Muma; Iphiseiodes zuluagai } \\
\text { Denmark and Muma }\end{array}$ & Ferreira et al., 2020 \\
\hline Alfafa & Medicago sativa L. & Predatory mites & Euseius scutalis (Athias-Henriot) & Al-Shammery, 2011 \\
\hline Almond & $\begin{array}{l}\text { Prunus amygdalis Batsch; } \\
\text { Prunus dulcis (Mill.) D. }\end{array}$ & Predatory mites & $\begin{array}{l}\text { Iphiseius degenerans (Berlese); Euseius } \\
\text { stipulatus (Athias-Henriot); Euseius tularensis } \\
\text { (Congdon); Neoseiulus californicus (McGregor); } \\
\text { Typhlodromus (Anthoseius) athenas Swirski } \\
\text { and Ragusa; Typhlodromus foenilis Oudeman }\end{array}$ & $\begin{array}{l}\text { Ouyang et al., 1992; Van Rijn and } \\
\text { Tanigoshi, 1999a; Bouras and } \\
\text { Papadoulis, 2005; Papadopoulos and } \\
\text { Papadoulis, 2008; Kolokytha et al., } \\
\text { 2011; Khanamani et al., } 2017\end{array}$ \\
\hline Amazonian palm & Euterpe oleracea Mart. & Predatory mites & $\begin{array}{l}\text { Amblyseius aerialis Muma; Iphiseiodes zuluagai } \\
\text { Denmark and Muma }\end{array}$ & Ferreira et al., 2020 \\
\hline Aninga & $\begin{array}{l}\text { Montrichardia linifera (Arr.) } \\
\text { Schott }\end{array}$ & Predatory mites & $\begin{array}{l}\text { Amblyseius aerialis Muma; Iphiseiodes zuluagai } \\
\text { Denmark and Muma }\end{array}$ & Ferreira et al., 2020 \\
\hline Annual mercury & Mercurialis annua L. & Predatory mites & Typhlodromus pyri (Sheuten) & Engel and Ohnesorge, 1994 \\
\hline Apple & $\begin{array}{l}\text { Malus domestica L.; Malus } \\
\text { sylvestris Mill. }\end{array}$ & Predatory mites & $\begin{array}{l}\text { Amblyseius swirskii (Athias-Henriot); Euseius } \\
\text { finlandicus Oudemans; Euseius tularensis } \\
\text { (Congdon); Iphiseius degenerans (Berlese); } \\
\text { Neoseiulus cucumeris (Oudemans); } \\
\text { Typhlodromus (Anthoseius) athenas Swirski } \\
\text { and Ragusa; Typhlodromus foenilis Oudeman }\end{array}$ & $\begin{array}{l}\text { Ouyang et al., 1992; Van Rijn and } \\
\text { Tanigoshi, 1999a; Broufas and } \\
\text { Koveos, 2000; Papadopoulos and } \\
\text { Papadoulis, 2008; Kolokytha et al., } \\
\text { 2011; Delisle et al., 2015a,b }\end{array}$ \\
\hline Apricot & Prunus armeniaca L. & Predatory mites & $\begin{array}{l}\text { Amblyseius swirskii (Athias-Henriot); Iphiseius } \\
\text { degenerans (Berlese); Euseius finlandicus } \\
\text { Oudemans; Euseius stipulatus (Athias-Henriot); } \\
\text { Neoseiulus californicus (McGregor); } \\
\text { Typhlodromus (Anthoseius) athenas Swirski } \\
\text { and Ragusa; Typhlodromus foenilis Oudeman }\end{array}$ & $\begin{array}{l}\text { Van Rijn and Tanigoshi, 1999a; } \\
\text { Broufas and Koveos, 2000; Bouras } \\
\text { and Papadoulis, 2005; Papadopoulos } \\
\text { and Papadoulis, 2008; Kolokytha } \\
\text { et al., 2011; Fadaei et al., 2018; } \\
\text { Soltaniyan et al., } 2018\end{array}$ \\
\hline Avocado & Persea americana Mill. & Predatory mites & Euseius hibisci (Chant) & McMurtry and Scriven, 1964 \\
\hline Bermuda buttercup & $\begin{array}{l}\text { Oxalis pes-caprae L.; Oxalis } \\
\text { sp. }\end{array}$ & Predatory mites & $\begin{array}{l}\text { Typhlodromus pyri (Sheuten); Cydnodromus } \\
\text { picanus Ragusa }\end{array}$ & $\begin{array}{l}\text { Ragusa et al., 2000; Bermúdez et al., } \\
2010\end{array}$ \\
\hline $\begin{array}{l}\text { Betulaceous plants } \\
\text { (e.g., alder, birch and } \\
\text { hazel) }\end{array}$ & $\begin{array}{l}\text { Alnus incana (L.) Muench; } \\
\text { Betula pubescens Ehrh., } \\
\text { Betula pendula Roth.; } \\
\text { Carpinus betulus L., Corylus } \\
\text { avellana L.; Corylus } \\
\text { americana Marsh.; Alnus } \\
\text { rubra Bong.; Turnera } \\
\text { ulmifolia L. }\end{array}$ & Predatory mites & $\begin{array}{l}\text { Amblydromalus limonicus (Garman and } \\
\text { McGregor); Amblyseius andersoni Chant; } \\
\text { Amblyseius largoensis (Muma); Amblyseius } \\
\text { swirskii (Athias-Henriot); Euseius addoensis } \\
\text { Van der Merwe and Rijke); Euseius finlandicus } \\
\text { (Oudemans); Iphiseius degenerans (Berlese); } \\
\text { Neoseiulus cucumeris (Oudemans); } \\
\text { Typhlodromus pyri (Scheuten) }\end{array}$ & $\begin{array}{l}\text { Saito and Mori, 1975; Overmeer, } \\
\text { 1981; Englert and Maixner, 1988; } \\
\text { Grout and Richards, 1992; Engel and } \\
\text { Ohnesorge, 1994; Kostiainen and } \\
\text { Hoy, 1994; Schausberger, 1997; Van } \\
\text { Rijn and Tanigoshi, 1999a; Addison } \\
\text { et al., 2000; Goleva et al., 2015; } \\
\text { Ferreira et al., } 2020\end{array}$ \\
\hline Bitter melon & Momordica charantia L. & Anthocorids & Orius sauteri (Poppius) & Zhou and Wang, 1989 \\
\hline Brazilian oil palm & Elaeis oleifera Cort. & Predatory mites & $\begin{array}{l}\text { Amblyseius aerialis Muma; Iphiseiodes zuluagai } \\
\text { Denmark and Muma }\end{array}$ & Ferreira et al., 2020 \\
\hline Broad bean & Vicia fabae L. & Predatory mites & $\begin{array}{l}\text { Iphiseius degenerans (Berlese); Neoseiulus } \\
\text { cucumeris (Oudemans) }\end{array}$ & $\begin{array}{l}\text { Van Rijn and Sabelis, 1990; Van Rijn } \\
\text { and Tanigoshi, 1999a; Nomikou et al., } \\
2001\end{array}$ \\
\hline Castor bean & Ricinus communis L. & Predatory mites & $\begin{array}{l}\text { Amblyseius gossypi Elbadry; Amblyseius } \\
\text { herbicolus (Banks); Amblyseius idaeus } \\
\text { (Denmark and Muma); Amblyseius largoensis } \\
\text { (Muma); Amblyseius zaheri Yousef and } \\
\text { El-Borolossy; Euseius hibisci (Chant); Euseius } \\
\text { mesembrinus (Dean); Euseius scutalis } \\
\text { (Athias-Henriot); Euseius tularensis (Congdon); } \\
\text { Euseius yousefi Zaher and El-Borolossy; } \\
\text { Iphiseius degenerans (Berlese); Neoseiulus } \\
\text { cucumeris (Oudemans); Phytoseius plumifer } \\
\text { (Canestrini and Fanzago); Typhlodromalus } \\
\text { aripo DeLeon; Typhlodromus negevi Swirski } \\
\text { and Amitai; Typhlodromus pyri Scheuten }\end{array}$ & $\begin{array}{l}\text { Dosse, 1961; McMurtry and Scriven, } \\
\text { 1964; McMurtry and Johnson, 1965; } \\
\text { Rasmy and El-Banhawy, 1975; } \\
\text { Momen and El-Saway, 1993; } \\
\text { Tanigoshi et al., 1993; Yue et al., } \\
\text { 1994; Ramakers and Voet, 1995; Yue } \\
\text { and Tsai, 1996; Van Rijn and } \\
\text { Tanigoshi, 1999a; Van Rijn et al., } \\
\text { 2002; Momen, 2004; Gnanvossou } \\
\text { et al., 2005; Skirvin et al., 2006; } \\
\text { Momen et al., 2009; Al-Shammery, } \\
\text { 2011; Rodríguez-Cruz et al., 2013 }\end{array}$ \\
\hline Cat grass & Dactylis glomerata L. & Predatory mites & Typhlodromus pyri (Sheuten) & Engel and Ohnesorge, 1994 \\
\hline
\end{tabular}


TABLE 5 | Continued

\begin{tabular}{|c|c|c|c|}
\hline $\begin{array}{l}\text { Plant (common } \\
\text { name) }\end{array}$ & Plant (Latin name) & $\begin{array}{l}\text { Category natural } \\
\text { enemy }\end{array}$ & Natural enemy \\
\hline Cattail & $\begin{array}{l}\text { Typha spp.: Typha } \\
\text { angustifolia L.; Typha } \\
\text { domingensis Pers.; Typha } \\
\text { latifolia L.; Typha orientalis } \\
\text { Presl. }\end{array}$ & Predatory mites & $\begin{array}{l}\text { Amblydromalus limonicus (Garman and } \\
\text { McGregor); Amblyseius andersoni Chant; } \\
\text { Amblyseius herbicolus (Banks); Amblyseius } \\
\text { largoensis (Muma); Amblyseius swirskii } \\
\text { (Athias-Henriot); Iphiseius degenerans } \\
\text { (Berlese); Euseius concordis (Chant); Euseius } \\
\text { finlandicus (Oudemans); Euseius gallicus } \\
\text { (KreiterandTixier), Euseius hibisci (Chant); } \\
\text { Euseius ovalis (Evans); Euseius stipulatus } \\
\text { (Athias-Henriot); Euseius mesembrinus (Dean); } \\
\text { Neoseiulus californicus (McGregor); Neoseiulus } \\
\text { cucumeris (Oudemans); Proprioseiopsis asetus } \\
\text { Muma; Typhlodromus (Anthoseius) athenas } \\
\text { Swirski and Ragusa }\end{array}$ \\
\hline
\end{tabular}

Cherry (sweet) $\quad$ Prunus avium L. Predatory mites

$\begin{array}{lll}\text { Chili pepper } & \text { Capsicum frutescens } \mathrm{L} . & \text { Predatory mites } \\ \text { China rose } & \begin{array}{l}\text { Rosa chinensis Rehder and } \\ \text { Wils. }\end{array} & \text { Anthocorids } \\ \text { Coconut } & \text { Cocos nucifera L. } & \text { Predatory mites }\end{array}$

Common henbit

Common

meadow-grass

Common mugwort

Common sowthistle

Common wild poppy

Corn

Corn

Corn

Zea mays $\mathrm{L}$.

Lamium amplexicaule L.

Poa pratensis $\mathrm{L}$.

Artemisia vulgaris $\mathrm{L}$.

Sonchus oleraceous $\mathrm{L}$.

Papaver rhoeas $L$.

Zea mays L.

Zea mays L.

Predatory mites

Corn

Zea mays L.
Predatory mites

Predatory mites

Predatory mites

Predatory mites

Predatory mites

Anthocorids

Coccinellids

Coleomegilla maculata (De Geer)

Typhlodromus pyri (Sheuten)

Typhlodromus pyri (Sheuten)

Euseius finlandicus Oudemans
Iphiseius degenerans (Berlese); Euseius concordis (Chant); Euseius finlandicus Oudemans; Euseius stipulatus (Athias-Henriot); Neoseiulus cucumeris (Oudemans); Typhlodromus (Anthoseius) athenas Swirski and Ragusa; Typhlodromus foenilis Oudeman Amblyseius herbicolus (Banks)

Orius sauteri (Poppius)

Amblyseius aerialis Muma; Iphiseiodes zuluagai Denmark and Muma; Neoseiulus paspalivorus DeLeon; Proctolaelaps bickleyi Bram

Neoseiulus californicus (McGregor)

Neoseiulus californicus (McGregor)

Orius insidiosus (Say); Orius sauteri (Poppius)

Amblydromalus limonicus (Garman and McGregor); Amblyseius swirskii (Athias-Henriot); Euseius concordis Chant; Euseius hibisci (Chant); Euseius fustis Pritchard and Baker; Euseius scutalis (Athias-Henriot); Iphiseiodes zuluagai Denmark and Muma; Neoseiulus barkeri Hugues; Neoseiulus californicus (McGregor); Phytoseius plumifer (Canestrini and Fanzago); Typhlodromalus aripo DeLeon; Typhlodromalus manihoti Moraes; Typhlodromus pyri Scheuten
Source

Kennett et al., 1979; Ouyang et al., 1992; Kostiainen and Hoy, 1994; Yue et al., 1994; Yue and Tsai, 1996; Van Rijn et al., 1999; Nomikou et al., 2002; Nomikou, 2003; Emmert et al., 2008; Messelink et al., 2008; Park et al., 2010, 2011; Tuovinen and Lindqvist, 2010; Kolokytha et al., 2011; Goleva and Zebitz, 2013; Nguyen et al., 2013, 2014a,b; Pijnakker et al., 2014, 2016; Vangansbeke et al., 2014a, 2016a; Nguyen et al., 2015; Duarte et al., 2015; Leman and Messelink, 2015; Samaras et al., 2015; Massaro et al., 2016; Beltrà et al., 2017; Liu and Zhang, 2017; Muñoz-Cárdenas et al., 2017; De Figueiredo et al., 2018; Liu et al., 2019; Ferreira et al., 2020; Pascua et al., 2020

Van Rijn and Tanigoshi, 1999a; Broufas and Koveos, 2000; Bouras and Papadoulis, 2005; Papadopoulos and Papadoulis, 2008

Duarte et al., 2015

Zhou and Wang, 1989

Lawson-Balagbo et al., 2007; Ferreira et al., 2020

Gugole Ottaviano et al., 2015

Engel and Ohnesorge, 1994

Engel and Ohnesorge, 1994

Gugole Ottaviano et al., 2015

Broufas and Koveos, 2000

Richards, 1992; Funao and Yoshiyasu, 1995; Richards and Schmidt, 1995

Smith, 1960a,b; Hodek et al., 1978; Lundgren and Wiedenmann, 2004; Lundgren et al., 2005; Michaud and Grant, 2005

McMurtry and Scriven, 1964; Engel and Ohnesorge, 1994; Gnanvossou et al., 2005; Weintraub et al., 2009; Onzo et al., 2012; Saber, 2012, 2013; Goleva and Zebitz, 2013; Khodayari et al., 2013; Adar et al., 2014; Vieira Marques et al., 2014; Leman and Messelink, 2015;

Samaras et al., 2015; Palevsky, 2016; Rezaie and Askarieh, 2016;

Khanamani et al., 2017; Rezaie, 2017

Zhang et al., 2004 
TABLE 5 | Continued

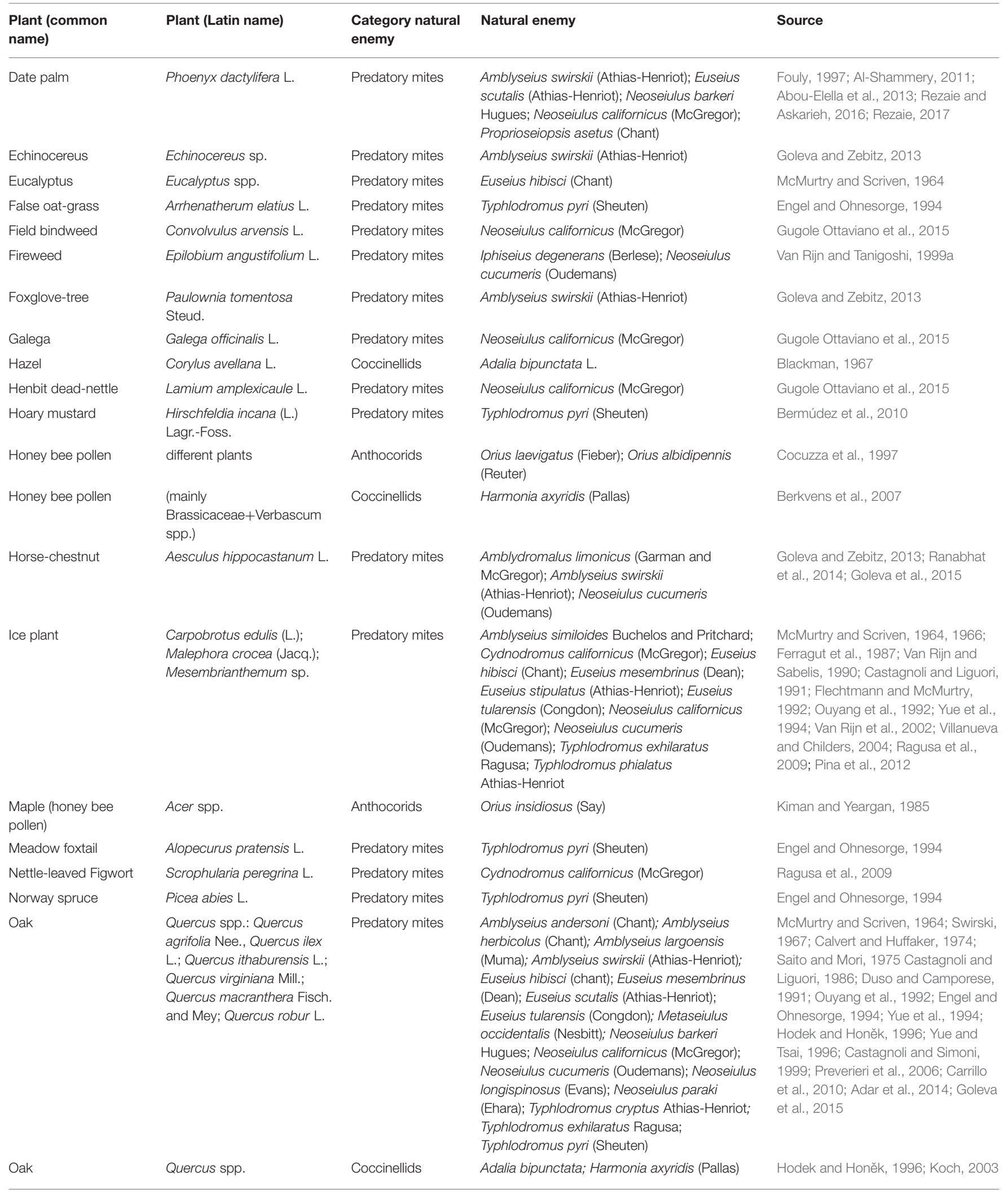


TABLE 5 | Continued

\begin{tabular}{|c|c|c|c|c|}
\hline $\begin{array}{l}\text { Plant (common } \\
\text { name) }\end{array}$ & Plant (Latin name) & $\begin{array}{l}\text { Category natural } \\
\text { enemy }\end{array}$ & Natural enemy & Source \\
\hline Oil palm & Elaeis guineensis Jacq. & Predatory mites & $\begin{array}{l}\text { Amblyseius aerialis Muma; Iphiseiodes zuluagai } \\
\text { Denmark and Muma }\end{array}$ & Ferreira et al., 2020 \\
\hline Olive & Olea europaea L. & Predatory mites & $\begin{array}{l}\text { Amblydromalus limonicus (Garman and } \\
\text { McGregor); Amblyseius swirskii } \\
\text { (Athias-Henriot); Euseius tularensis (Congdon); } \\
\text { Typhlodromus (Anthoseius) athenas Swirski } \\
\text { and Ragusa; Neoseiulus cucumeris } \\
\text { (Oudemans) }\end{array}$ & $\begin{array}{l}\text { Ouyang et al., 1992; Matsuo et al., } \\
\text { 2003; Kolokytha et al., 2011; Kumar } \\
\text { et al., 2014; Samaras et al., } 2015\end{array}$ \\
\hline Passion fruit & Passiflora edulis Sims & Predatory mites & $\begin{array}{l}\text { Amblyseius aerialis Muma; Iphiseiodes zuluagai } \\
\text { Denmark and Muma }\end{array}$ & Ferreira et al., 2020 \\
\hline Peach & Prunus persica L. & Predatory mites & Euseius tularensis (Congdon) & Ouyang et al., 1992 \\
\hline Pear & Pyrus communis L. & Predatory mites & $\begin{array}{l}\text { Iphiseius degenerans (Berlese); Euseius } \\
\text { finlandicus Oudemans; Euseius tularensis } \\
\text { (Congdon); Neoseiulus cucumeris (Oudemans); } \\
\text { Typhlodromus (Anthoseius) athenas Swirski } \\
\text { and Ragusa; Typhlodromus foenilis Oudeman }\end{array}$ & $\begin{array}{l}\text { Ouyang et al., 1992; Van Rijn and } \\
\text { Tanigoshi, 1999a; Broufas and } \\
\text { Koveos, 2000; Matsuo et al., 2003; } \\
\text { Papadopoulos and Papadoulis, 2008; } \\
\text { Kolokytha et al., } 2011\end{array}$ \\
\hline $\begin{array}{l}\text { Pine (black, turkish, } \\
\text { calabrian) }\end{array}$ & $\begin{array}{l}\text { Pinus sp.; Pinus brutia Ten.; } \\
\text { Pinus nigra L. }\end{array}$ & Predatory mites & $\begin{array}{l}\text { Amblydromalus limonicus (Garman and } \\
\text { McGregor); Amblyseius swirskii } \\
\text { (Athias-Henriot); Iphiseius degenerans } \\
\text { (Berlese); Neoseiulus cucumeris (Oudemans); } \\
\text { Typhlodromus pyri (Sheuten) }\end{array}$ & $\begin{array}{l}\text { Engel and Ohnesorge, 1994; Van Rijn } \\
\text { and Tanigoshi, 1999a; Samaras et al., } \\
\text { 2015; Kütük, } 2018\end{array}$ \\
\hline Pistachio & Pistachio vera L. & Predatory mites & Neoseiulus californicus (McGregor) & Soltaniyan et al., 2018 \\
\hline Plum & Prunus domestica L. & Predatory mites & $\begin{array}{l}\text { Euseius stipulatus (Athias-Henriot); } \\
\text { Typhlodromus (Anthoseius) athenas Swirski } \\
\text { and Ragusa; Typhlodromus foenilis Oudeman }\end{array}$ & $\begin{array}{l}\text { Bouras and Papadoulis, 2005; } \\
\text { Papadopoulos and Papadoulis, 2008; } \\
\text { Kolokytha et al., } 2011\end{array}$ \\
\hline Pygmy date palm & Phoenix roebelenii O'Brien & Predatory mites & Amblyseius largoensis (Muma) & Yue and Tsai, 1996 \\
\hline Sunflower & Helianthus annuus L. & Predatory mites & $\begin{array}{l}\text { Amblyseius zaheri Yousef and El-Borolossy; } \\
\text { Euseius yousefi Zaher and El-Borolossy; } \\
\text { Iphiseius degenerans (Berlese); Neoseiulus } \\
\text { barkeri Hugues }\end{array}$ & $\begin{array}{l}\text { Van Rijn and Tanigoshi, 1999a; } \\
\text { Momen, 2004; Rezaie and Askarieh, } \\
\text { 2016; Ferreira et al., } 2020\end{array}$ \\
\hline Sunnhemp & Crotalaria juncea L. & Predatory mites & Amblyseius herbicolus (Banks) & Rodríguez-Cruz et al., 2013 \\
\hline Sweet orange & Citrus sinensis L. & Predatory mites & $\begin{array}{l}\text { Amblyseius aerialis Muma; Iphiseiodes zuluagai } \\
\text { Denmark and Muma }\end{array}$ & Ferreira et al., 2020 \\
\hline Sweet pepper & $\begin{array}{l}\text { Capsicum annuum L. cv. } \\
\text { Mazurka }\end{array}$ & Anthocorids & $\begin{array}{l}\text { Orius albidipennis Reuter; Orius laevigatus } \\
\text { (Fieber) }\end{array}$ & Vacante et al., 1997 \\
\hline $\begin{array}{l}\text { Sweet pepper, } \\
\text { ornamental pepper, } \\
\text { peper }\end{array}$ & $\begin{array}{l}\text { Capiscum annum } \mathrm{L} \text {.; } \\
\text { Capsicum frutescens } \mathrm{L} \text {. }\end{array}$ & Predatory mites & $\begin{array}{l}\text { Amblyseius swirskii (Athias-Henriot); Euseius } \\
\text { hibisci (Chant); Neoseiulus cucumeris } \\
\text { (Oudemans) }\end{array}$ & $\begin{array}{l}\text { McMurtry and Scriven, 1964; Van Rijn } \\
\text { and Sabelis, 1990; Kumar et al., } 2014\end{array}$ \\
\hline Tea & Camellia sinensis L. & Predatory mites & $\begin{array}{l}\text { Amblyseius sojaensis Ehara; Neoseiulus } \\
\text { cucumeris (Oudemans) }\end{array}$ & $\begin{array}{l}\text { Osakabe et al., 1986; Matsuo et al., } \\
2003\end{array}$ \\
\hline Tulip & $\begin{array}{l}\text { Tulipa sp.; Tulipa gesneriana } \\
\text { L. }\end{array}$ & Predatory mites & $\begin{array}{l}\text { Neoseiulus cucumeris (Oudemans); } \\
\text { Amblyseius swirskii (Athias-Henriot) }\end{array}$ & $\begin{array}{l}\text { Ranabhat et al., 2014; Goleva et al., } \\
2015\end{array}$ \\
\hline Turkish pine & Pinus brutia (Ten.) & Predatory mites & Amblyseius swirskii (Athias-Henriot) & Kütük and Yigit, 2011 \\
\hline
\end{tabular}


TABLE 5 | Continued

\begin{tabular}{|c|c|c|c|c|}
\hline $\begin{array}{l}\text { Plant (common } \\
\text { name) }\end{array}$ & Plant (Latin name) & $\begin{array}{l}\text { Category natural } \\
\text { enemy }\end{array}$ & Natural enemy & Source \\
\hline Walnut & Juglans regia L. & Predatory mites & $\begin{array}{l}\text { Amblyseius swirskii (Athias-Henriot); Euseius } \\
\text { hibisci (Chant); Euseius finlandicus Oudemans; } \\
\text { Neoseiulus barkeri Hugues, Neoseiulus } \\
\text { californicus (McGregor); Typhlodromus } \\
\text { (Anthoseius) athenas Swirski and Ragusa; } \\
\text { Typhlodromus foenilis Oudemans; } \\
\text { Typhlodromus pyri (Sheuten) }\end{array}$ & $\begin{array}{l}\text { McMurtry and Scriven, 1964; Engel } \\
\text { and Ohnesorge, } 1994 \text { Broufas and } \\
\text { Koveos, 2000; Papadopoulos and } \\
\text { Papadoulis, 2008; Kolokytha et al., } \\
\text { 2011; Rezaie and Askarieh, 2016; } \\
\text { Rezaie, 2017; Fadaei et al., } 2018\end{array}$ \\
\hline Willow & Salix sp. & Coccinellids & Adalia bipunctata L. & Blackman, 1967 \\
\hline
\end{tabular}

1996; Cocuzza et al., 1997; Coll, 1998; Lundgren, 2009). However, the development of Orius spp. was prolonged and reproduction and survival reduced on pollen only diet (Salas-Aguilar and Ehler, 1977; Kiman and Yeargan, 1985; Funao and Yoshiyasu, 1995; Richards and Schmidt, 1996; Cocuzza et al., 1997; Vacante et al., 1997,?). As with the phytoseiids, Orius performance is dependent on pollen type (Vacante et al., 1997). Pollen feeding also provides benefits for M. pygmaeus (Perdikis and Lykouressis, 2000; Vandekerkhove and De Clercq, 2010; Portillo et al., 2012; Put et al., 2012). Cattail pollen doubled the longevity of $M$. pygmaeus females compared to bugs provided only broad beans (Portillo et al., 2012) and promoted its establishment on tomato plants (Put et al., 2012). Also larvae of green lacewings can benefit from (bee) pollen (Patt et al., 2003). For syrphids, sexual maturation requires proteins that can be provided by pollen, allowing the females to mature successive batches of eggs (Schneider, 1948; Pineda and Marcos-García, 2008).

In biological control, pollen has been reported to support population densities of natural enemies when prey densities are low and improve control efficacy against pests. Most of these studies concern predatory mites. In the presence of pollen, predatory mites provided better control of phytophagous mites (McMurtry and Scriven, 1966; Kennett et al., 1979; Ferragut et al., 1987; Pina et al., 2012, 2015; Saber, 2013; Maoz et al., 2014; Duarte et al., 2015; Pijnakker et al., 2016), thrips (Ramakers, 1990; Van Rijn and Sabelis, 1993; Van Rijn et al., 1999) and whiteflies (Nomikou et al., 2001, 2002, 2010; Nomikou, 2003). Van Rijn et al. (1999) were the first to provide clear experimental evidence that supplementing pollen can be an efficient strategy to boost the biological control potential of predatory mites. By supplying the predatory mite species A. limonicus and I. degenerans with cattail pollen they were able to enhance population levels of the predatory mites, which resulted in increased thrips control and reduced plant damage. Kütük and Yigit (2011) succeeded in pre-establishing $A$. swirskii on sweet pepper by spraying suspensions of pine pollen, thereby maintaining F. occidentalisnumbers under the desired threshold. Provision of cattail or corn pollen increased densities of $A$. swirskii and improved thrips control on potted chrysanthemum (Leman and Messelink, 2015). Muñoz-Cárdenas et al. (2017) succeeded in establishing A. swirskii in roses before thrips release by weekly provision of cattail pollen and thus managed to realize a decrease of thrips numbers and damage. Nomikou et al. (2002, 2010) showed improved suppression of tobacco whitefly populations by $A$. swirskii on single cucumber plants treated with cattail pollen. Skirvin et al. (2006) achieved a higher density of N. cucumeris on chrysanthemum plants with an application of castor bean pollen. Still, it led to an increased infestation of western flower thrips, as only a few predatory mites were recovered. These examples give an idea of the potential of pollen as alternative food but the studies were often performed over short temporal scales and at pest densities higher than those found in commercial greenhouses. Since cattail pollen has been made commercially available in 2013, growers can now apply pollen as part of biocontrol programs. They typically apply pollen weekly (blown at $250 \mathrm{~g} / \mathrm{ha}$ ) or biweekly (at $500 \mathrm{~g} / \mathrm{ha}$ ) (Pijnakker et al., 2016). These dosages correspond to 2.5 to $20 \mathrm{mg}$ per plant. Various devices are available to apply pollen to enhance the establishment of predatory mites on crops (Gan-Mor et al., 2003, 2011; Weintraub et al., 2009; Pijnakker et al., 2016). Other arguments in favor of the use of cattail pollen, next to its high nutritional value, are its low allergenic character (Weber and Nelson, 1985), its relatively low attractiveness to pests and poor nutritional suitability for thrips (Hulshof et al., 2003). The fact that cattail pollen is not attractive to (bumble) bees, means that it does not distract pollinators used in the crop (Schmidt et al., 1989).

However, the use of pollen can have some drawbacks as it can also benefit herbivores (Kirk, 1987; Van Rijn et al., 2002; Chitturi et al., 2006; Wäckers et al., 2007, Leman and Messelink, 2015; Vangansbeke et al., 2016b). Hulshof et al. (2003) showed at laboratory scale that $F$. occidentalis feeds on pollen, resulting in an enhancement of its growth rate and fecundity. Van Rijn et al. (2002), using simulation models, showed that availability of pollen benefits predators more than thrips and improved predator-prey ratios resulting in enhanced thrips control. This has since been repeatedly confirmed in studies showing the efficacy of the pollen supplementation at plant or crop level (see above). The high reproduction by $A$. swirskii on plants treated with pollen prevented the pest from developing, even if they can feed on the pollen. This represents an example of apparent competition, where the population development of a prey is suppressed by a shared predator when an additional prey or food supplement is present (Nomikou et al., 2010). Despite the fact that Typha pollen has been widely shown to be effective in supporting biological control, growers could still run a risk of damage when thrips are too numerous at the start of the 
crop or when predators do not establish because of pesticide residues. When applying any food supplement, including pollen, predation per predatory mite will go down due to satiation effects (Skirvin et al., 2007). In addition to predator satiation (Holt and Lawton, 1993, 1994; Shakya et al., 2009) a feedingswitch to pollen may occur. Both mechanisms may result in a temporary reduction in predation rate of the pest (so-called apparent mutualism, Abrams and Matsuda, 1996). High dosage of cattail pollen reduced the predation of thrips by individual A. swirskii by $50 \%$ on laboratory scale (Leman and Messelink, 2015). However, these effects are typically short term and are soon outbalanced by the augmentation of natural enemy numbers (Van Rijn et al., 1999).

The use of supplementary food, and pollen in particular, is a powerful tool to help establish predatory mites and improve biocontrol efficacy. The application of exogenous pollen as supplemental food source can be optimized by avoiding excessive doses, as overly high pollen levels may result in satiation of predatory mites and stimulation of thrips (Sabelis and van Rijn, 2006). The choice of the pollen type and the match with the predatory mite can also affect the outcome. However, Typha pollen has proved to be suitable for a broad range of predatory mites (Table 5). Growers succeed in building strong populations of predatory mites with feeding their predators before pest appearance and performing adjustments in their irrigation systems and their spraying data. Some persue the development of the application by automatizing the blowing of this alternative food.

\section{NECTAR/SUGAR SOLUTION}

Many natural enemies depend on sugars as their main source of energy. This includes a.o. parasitoids (Wäckers, 2001), syrphids (Van Rijn and Wäckers, 2016), gall midges (Fratoni et al., 2020), chrysopids (Stelzl, 1991; Hogervorst et al., 2007), coccinellids (Pemberton and Vandenberg, 1993), mirids (Portillo et al., 2012), and phytoseiids (Van Rijn and Tanigoshi, 1999b). Natural enemies can feed from a range of carbohydrate sources. Besides floral nectar, they can also exploit extrafloral nectar, as well as honeydew.

Floral nectar has evolved as a food reward in the mutualism between plants and their pollinators. Even though natural enemies, with a few noticeable exceptions (Pekas et al., 2020), are most likely not necessarily effective in pollinating flowers, they, nevertheless, can collect floral nectar to provide for their energetic needs. As natural enemies tend to have short mouthparts, their nectar foraging is restricted to those plant species with open and exposed floral nectaries, such as Apiaceae, Euphorbiaceae, or buckwheat (Campbell et al., 2012; Wäckers and van Rijn, 2012; Van Rijn and Wäckers, 2016).

While accessibility of floral nectar can be a bottleneck for natural enemies, some plants also produce nectar outside of the flowers. These so-called extrafloral nectaries tend to be exposed and thus highly accessible. Furthermore, the nectar is often secreted over prolonged periods of time (Wäckers and Bonifay, 2004). These adaptations fit their ecological function, as extrafloral nectar is part of a defensive strategy, allowing plants to recruit ants and other sugar feeding natural enemies. They, in turn, protect the plants when attacking herbivores. Extrafloral nectaries have been described in more than thousand plant species, including a number of important crops, such as cotton, cassava, peaches, plums, cherries, pumpkins, roses, field beans. In a number of plant systems, it has been demonstrated that the presence of extrafloral nectar can translate into both reduced plant damage and increased plant reproductive fitness (Heil, 2015).

Honeydew is a generic term for sugar-rich excretions of phloem-feeding Sternorrhyncha. In agricultural ecosystems, honeydew is often the most prevalent sugar source (Wäckers and Steppuhn, 2003; Hogervorst et al., 2007; Tena et al., 2015). However, honeydew differs from the above-mentioned sugar sources, as it is primarily a waste product. This can reduce the nutritional value of honeydew (Wäckers et al., 2008).

Overall, the nutritional suitability of the above sugar sources depends on composition and concentration of carbohydrates (Wäckers, 2001; Azzouz et al., 2004; Fratoni et al., 2020). Sugar concentration is an important factor determining sugar uptake. At low concentrations, gustatory perception might be impeded (Wäckers, 1999), whereas viscosity at high sugar concentrations can interfere with sugar uptake (Wäckers, 2000; Winkler et al., 2009). Upon the time of nectar secretion, sugar concentrations can already range from 5 to $75 \%$ (Dafni, 1992). Environmental conditions may further affect nectar concentrations both indirectly through their effects on the nectar producing plant, and directly through evaporation, hygroscopy or rain dilution (Winkler et al., 2009). Sugar concentrations of undiluted extrafloral nectar range from 5 to more than $80 \%$ (Koptur, 1992a,b; Wäckers, 2001). In general, extra floral nectar shows much more variation in terms of sugar concentration than floral nectar from the same plant. Extrafloral nectar tends to be more concentrated, probably due the fact that its exposed nature increases evaporation. The fact that honeydew is typically available as little droplets or as a thin film on the substrate, means that it is even more subjected to evaporation. As a result, sugar concentrations are often at saturation. This is likely to be a limiting factor in honeydew uptake. This problem is accentuated by the specific tendency of the honeydew sugars: raffinose and melezitose, to crystallize rapidly (Wäckers, 2000).

\section{Providing Sugar Sources to Boost Biological Pest Control}

It has long been recognized that the lack of sugar sources in agricultural systems can strongly undermine the efficacy of biological control. This problem could be overcome by introducing food sources into our agricultural systems. Recently, we have seen an increasing interest in the use of (flowering) noncrop plants in field margins as a tool to sustain predators and parasitic wasps. Specifically selected seed mixtures are available 
that are intended to attract natural enemies and provide them with nectar sources. When introducing nectar plants, the use of sugar sources is not restricted to beneficial insects. Many pest insects thrive on sweets as well (Wäckers et al., 2007). By choosing plants that primarily benefit natural enemies, the positive impact on pest control can be maximized (Gurr, 2005; Winkler et al., 2010). Banker plants can also be used to provide sugar sources, either in the form of (extra-) floral nectar as in the case of castor bean or broad bean or by providing honeydew (considering the caveats mentioned above). As an alternative to the introduction of nectar- or honeydew providing plants, sugar can also be applied as such. Sugar can be either sprayed onto the crop, or provided in so-called "feeding stations." Spraying sugar has the advantage that it is an easy and cheap application method resulting in an even coverage and providing an easily accessible sugar source for the predators and parasitoids. The quantity of the sugar applied can be controlled through the choice of sugar concentration, by adjusting the spray volume/spray nozzle, and by varying the walking/driving speed. Yet, there are also obvious drawbacks to the use of sugar sprays. Blanket sprays quickly result in the crop getting sticky. Certain sugars can cause phytotoxicity when sprayed directly on the foliage. In addition, sugars on the plant surface are prone to growth of sooty mold. These drawbacks can be avoided, either by using very weak sugar concentrations (e.g., $0.1-1 \%$ ) or by applying a higher concentrated solution in a very fine and light mist. For the target arthropods, having minute sugar droplets is often better than having to deal with a sticky sugar layer, as the latter interferes with arthropod mobility. Biological control practitioners have attempted to incorporate artificial sugar sprays as a strategy to cater to the nutritional needs of parasitoids (Mandour et al., 2007; Wade et al., 2008). However, the efficacy of this form of sugar provisioning in biological control programmes has been limited and inconsistent (Heimpel and Jervis, 2005; Wade et al., 2008). Tena et al. (2015) studied the use of sugar sprays in combination with the release of the parasitoid Aphytis melinus DeBach (Hymenoptera: Aphelinidae) for the control of the California red scale Aonidiella aurantii in a commercial citrus orchard. They demonstrated that sugar supplementation increased the parasitoid population density 2-fold. Parasitoid fecundity on sugar treated trees was shown to be enhanced as well. Higher population densities and the increase in realized fecundity translated in a 2 -fold increase in parasitism under crop conditions. The successful examples show that under certain conditions the use of sugars can be an effective element in a conservation biological control strategy.

\section{DOMATIA}

Shelter and oviposition substrates are other resources that can be essential to successful establishment and efficacy of natural enemies (Gurr et al., 2017). Providing sites of refuge can support reproduction (Pemberton and Turner, 1989; O'Dowd and Willson, 1991; Grostal and O’Dowd, 1994; Walter, 1996) and development, overwintering or aestivation and can protect them from cannibalism (Ferreira et al., 2008; Lee and Zhang, 2016, 2018), predation (Roda et al., 2000; Norton et al., 2001; Faraji et al., 2002a,b; Romero and Benson, 2005; Seelmann et al., 2007; Ferreira et al., 2011) and unfavorable climatic conditions (Walter and O’Dowd, 1992a,b; Grostal and O’Dowd, 1994; Walter, 1996; Sabelis et al., 1999; Norton et al., 2001).

Some plants have special morphological structures, called domatia (from the Latin for home "domus"), that are targeted to either ants, or predatory/fungivorous mites. Ant domatia are represented by hollow thorns or stems and rolled leaf margins. Acarodomatia may take the form of either pits or (dense) tufts of leaf hairs, in which small arthropods may reside (Romero and Benson, 2005). Many studies have demonstrated that the presence of domatia increases the population of predators, that in turn protect the plant against herbivores and in some instances pathogens and weeds (Lundstrom, 1887; Rozario, 1995; Kreiter et al., 2003; Ferreira et al., 2008, 2011; Shenoy and Borges, 2010; Parolin et al., 2013). Predatory mites tend to occur more abundantly on plants bearing acarodomatia (O'Dowd and Willson, 1997; Norton et al., 2000; Roda et al., 2001; Romero and Benson, 2005; Avery et al., 2014) and their survival and reproduction on such plants is enhanced (Pemberton and Turner, 1989; Karban et al., 1995; Agrawal, 1997; Agrawal et al., 2000; Cortesero et al., 2000; Avery et al., 2014; Bresch et al., 2015, 2018). Domatia also act as oviposition substrate. Many predatory mite species show a preference to lay eggs on trichomes. Egg clusters can be frequently seen inside domatia, where predatory mites can molt protected from predators. Besides serving as shelters and oviposition sites, the hair-tufts may trap pollen and fungal spores that the mites can then consume (Roda et al., 2000; Romero and Benson, 2005; Loughner et al., 2008). Thus, acarodomatia can serve a function in providing food as well. Pekas and Wäckers (2017) showed a strong synergistic effect between the availability of fibers and food (pollen and sugar water) in affecting population growth of predatory mites on citrus plants. Romero and Benson (2004) demonstrated the protective role of domatia on the tropical tree Cupania vernalis L. By blocking domatia on part of the experimental trees, they showed that domatia increased predatory mite abundance and lowered herbivore damage from eriophyid mites. However, very few studies have investigated their long-term effect on predatory mites, pest or fungi under natural conditions (Norton et al., 2000; Monks et al., 2007; Ferreira et al., 2010). Norton et al. (2000) showed that acarodomatia increased the abundance of the mycophagous tydeid mite, Orthotydeus lambi (Baker), which resulted in the reduction of $48 \%$ of grape mildew infestation on the riverbank grape.

Domatia can be provided to beneficials by (1) selecting crop variety with the appropriate properties, (2) by adding suitable non-crop plants to crops (Skirvin and Fenlon, 2001; Van Rijn et al., 2002; Osborne and Barrett, 2005; Frank, 2010; Huang et al., 2011; Parolin et al., 2012b; Kumar et al., 2015), (3) or by using artificial structures (Loughner et al., 2011; Adar et al., 2014; Pekas and Wäckers, 2017). Crop varieties can differ substantially in domatia characteristics. Choosing crop 
varieties for their domatia traits could thus help to support establishment of natural enemies. Breeding programmes have actually started to include traits that determine suitability for beneficial organisms (Bottrell et al., 1998; English-Loeb et al., 1999). Some tomato varieties, for example, have been selected for their distorted trichomes to facilitate biological control of tomato russet mites (Van Houten et al., 2013; Legarrea et al., 2020). Another method for applying domatia can be the interplanting of domatia bearing banker plants between crop plants lacking domatia. Parolin et al. (2013) showed an increased spider mite control in roses using the predatory mites $P$. persimilis and Neoseiulus californicus (MCGregor) when adding lauristinus and frost grape bearing acarodomatia as bankerplants. Adding the banker plants in this system enhanced the establishment of predatory mites and increased their efficacy. The method can only be successful if natural enemies disperse from the manipulated habitat to the crop. In practice, growers tend to focus on commercial crops and are reluctant to introduce non-crop (banker) plants. A further strategy could be to use artificial domatia. Various types of artificial domatia have been used in studies to assess the benefits of natural dolmatia, but also, to improve biological control on crops (Loughner et al., 2010, 2011; Pekas and Wäckers, 2017). Rozario (1994) brought tufts of polyester fibers to grape varieties with low natural domatia to augment populations of Galendromus occidentalis Nesbitt. Agrawal and Karban (1997) supplemented cotton plants with artificial domatia, which enhanced spider mite control and fruit yields. However, thrips numbers were also shown to benefit from domatia. Kawashima et al. (2006a) reported laboratory experiments showing that textured urethane foam and polyethylene shading nets were suitable sites for the reproduction of N. californicus. Kawashima and Jung (2011) suggested using urethane foam as ground cover in apple orchards to increase the survival of $N$. californicus populations during the winter. Loughner et al. (2011) mimicked domatia on glabrous beans seedlings and Impatiens plants by adding cotton fiber patches and chopped acrylic yarn fibers and found more A. swirskii on plants provided with pollen and artificial domatia than on plants given solely pollen or fibers. In this study, cotton patches and paper pulp supplements augmented and maintained $A$. swirskii populations, whereas jute and celluflo were not effective. Adar et al. (2014) tested the "pollen on-twine" method (GanMor et al., 2011), using fibers (rayon/viscose $80 \%$ and jute $20 \%$ ) coated with pollen and succeeded in enhancing E. scutalis populations. Oviposition occurred on rayon rather than on jute. Bresch et al. (2018) found wool, silk, polyamide, viscose and polyester to be equally suitable as natural domatia for oviposition by N. californicus. However, none of them improved spider mite control by $\mathrm{N}$. californicus and polyamide even benefitted the pest. Pekas and Wäckers (2017) showed that the combined use of fibers, pollen, and sugar generate synergistic benefits to population growth of Euseius stipulatus (AthiasHenriot) on bitter orange. In orchards, Koike et al. (2000) designed a Phyto trap, which contains wool yarn mimicking the microstructure of spider mites colonies. This tool aims at collecting predatory mites in pear trees to monitor their densities during the seasons and maintain populations (Kawashima and Amano, 2006; Kawashima et al., 2006b). This tool inspired Messelink et al. (2016) to test among others further material with Velcro tape in greenhouse crops, but found that using millet husk or jute both combined with pollen were more effective to enhance the establishment of A. limonicus on anthurium. In spite of these examples showing the potential of using artificial domatia, there are no commercial applications of these artificial domatia yet.

\section{CONCLUSIONS}

This review presents the potential, advantages and risks of the concept of "beneficials-in-first" over augmentative biological control in greenhouses and aims at discussing tools thought to preserve natural enemies in biological control programmes. The studies described show that natural enemies' survival, development, reproduction and efficacy can be enhanced with the use of factitious prey, banker plant systems, pollen, sugars and manipulated habitats. This concept of "beneficials-in-first" is no longer a focus of researchers only, but has been explored by commercial growers over the past two decades. However, despite the trials demonstrating their benefit, some methods to enhance natural enemies' establishment are still excluded from biological strategies in practice, as they often lead to other issues at large scale. The development of hyperparasitoids or pests on banker plant systems, the possible molting of Ephestia eggs and Artemia cysts, the lack of survival of living factitious prey, the damages caused by Tyrophagus putrescentiae or by mirid predatory bugs when they are too numerous, are such examples. Overhead irrigation can hamper the application of alternative food and artificial domatia in some crops. Artificial domatia are also difficult for growers to introduce in their crop.

Further increasing the adoption of the "beneficials-in-first" concept by growers can be achieved by:

1. Clearly demonstrating efficacy on a larger scale and communicate if the selected resources benefit more natural enemies than the antagonists or pests, decrease pest damage and increase production quality or yield;

2. Increasing the involvement of growers in the process of such large-scale experiments, including costs and handling times;

3. Fine-tuning the amount of supplemental resources, the release techniques, the timing and the frequency with which the tools should be employed (Janssen and Sabelis, 2015; Madadi, 2018);

4. Automatization as it will be the key in expanding the scope of inoculative biological control, both in protected and openfield crops.

In the coming decade, we foresee more applications of feeding stations and nectar plants in crops to enhance the survival of natural enemies. Beside the tools of enhancement of beneficials, the use of methods limiting pest activity in greenhouses will gain more importance like tools of sexual confusion, 
distraction of pests such as "push-pull systems" or the use of "repellent substances."

\section{AUTHOR CONTRIBUTIONS}

JP: conceptualization, supervision, writing original draft, review, and editing. FW: conceptualization, supervision, writing draft, review, and editing. DV, RM, and $\mathrm{MD}$ : review and editing.

\section{REFERENCES}

Abe, J., Mitsunaga, T., Kumakura, H., and Yano, E. (2011). Comparative studies on development and reproduction of four cereal aphid species reared on sorghum or barley to evaluate as alternative prey for banker plant system. Japanese J. Appl. Entomol. Zool. 55, 227-239. doi: 10.1303/jjaez.20 11.227

Abou-Elella, G. M., Saber, S. A., and El-Sawi, S. A. (2013). Biological aspects and life tables of the predacious mites, Typhlodromips swirskii (AthiasHenriot) and Euseius scutalis (Athias-Henriot) feeding on two scale insect species and plant pollen. Arch. Phytopathol. Pflanzenschutz 46, 1717-1725. doi: 10.1080/03235408.2013.774715

Abrams, P. A. (1987). On classifying interactions between populations. Oecologia 73, 272-281. doi: 10.1007/BF00377518

Abrams, P. A., and Matsuda, H. (1996). Positive indirect effects between prey species that share predators. Ecology 77, 610-616. doi: 10.2307/2265634

Adar, E., Inbar, M., Gal, S., Doron, N., Zhang, Z. Q., and Palevsky, E. (2012). Plant-feeding and non-plant feeding phytoseiids: differences in behavior and cheliceral morphology. Exp. Appl. Acarol. 58, 341-357. doi: 10.1007/s10493-012-9589-y

Adar, E., Inbar, M., Gal, S., Gan-Mor, S., and Palevsky, E. (2014). Pollen on-twine for food provisioning and oviposition of predatory mites in protected crops. Biocontrol 59, 307-317. doi: 10.1007/s10526-014-9563-1

Addison, J. A., Hardman, J. M., and Wilde, S. J. (2000). Pollen availability for predaceous mites on apple: spatial and temporal heterogeneity. Exp. Appl. Acarol. 24, 1-18. doi: 10.1023/A:1006329819059

Agrawal, A. (1997). Do leaf domatia mediate a plant-mite mutualism? An experimental test of the effects on predators and herbivores. Ecol. Entomol. 22, 371-376. doi: 10.1046/j.1365-2311.1997.00088.x

Agrawal, A. A. (2005a). Future directions in the study of induced plant responses to herbivory. Entomol. Exp. Appl. 115, 97-105. doi: 10.1111/j.1570-7458.2005.00294.x

Agrawal, A. A. (2005b). Herbivory and maternal effects: mechanisms, ecological consequences and agricultural implications of tri-trophic interactions. Curr. Opin. Plant Biol. 3, 329-335. doi: 10.1016/S1369-5266(00)00089-3

Agrawal, A. A., Janssen, A., Bruin, J., Posthumus, M. A., and Sabelis, M. W. (2002). An ecological cost of plant defence: attractiveness of bitter cucumber plants to natural enemies of herbivores. Ecol. Lett. 5, 377-385. doi: 10.1046/j.1461-0248.2002.00325.x

Agrawal, A. A., and Karban, R. (1997). Domatia mediate plant arthropod mutualism. Nat. Rev. Mater. 387, 562-563. doi: 10.1038/42384

Agrawal, A. A., Karban, R., and Colfer, R. G. (2000). How leaf domatia and induced plant resistance affect herbivores, natural enemies and plant performance. Oikos 89, 70-80. doi: 10.1034/j.1600-0706.2000.890108.x

Agrawal, A. A., and Klein, C. N. (2000). What omnivores eat: direct effects of induced plant resistance on herbivores and indirect consequences for diet selection by omnivores. J. Econ. Entomol. 69, 525-535. doi: 10.1046/j.1365-2656.2000.00416.x

Agrawal, A. A., Kobayashi, C., and Thaler, J. S. (1999). Influence of prey availability and induced host-plant resistance on omnivory by western flower thrips. Trends Ecol. Evol. 80, 518-523. doi: 10.1890/0012-9658(1999)0800518:IOPAAI2.0.CO;2

Albajes, R., Castañé, C., Gabarra, R., and Alomar, O. (2006). "Risks of plant damage caused by natural enemies introduced for arthropod biological control," in Environmental Impact of Invertebrates for Biological Control of Arthropods:
All authors contributed to the article and approved the submitted version.

\section{ACKNOWLEDGMENTS}

We thank Isabelle Pijnakker, Neal Ward, and Laetitia Driss for their cooperation and their help in improving the manuscript.
Methods and Risk Assessment, eds. F. Bigler, D. Babendreier, U. Kuhlmann (Trowbridge: Cromwell Press), 132-144.

Albert, R. (1995). Biological control of the cotton aphid Aphis gossypii on cucumber. Taspo Gartenbau Magazin 4, 32-34.

Alomar, O., Arnó, J., and Gabarra, R. (2008). Insectary plants to enhance the biological control of Nasonovia ribisnigri and Frankliniella occidentalis in lettuce. IOBC/WPRS Bull. 34, 9-12.

Alomar, O., Castañé, C., Gabarra, R., Arnó, J., and Arino, J. (1991). Conservation of native mirid bugs for biological control in protected and outdoor tomato crops. IOBC/SROP Bull. 14, 33-42.

Alomar, O., Riudavets, J., and Castañé, C. (2006). Macrolophus caliginosus in the biological control of Bemisia tabaci on greenhouse melons. Biol. Control 36, 154-162. doi: 10.1016/j.biocontrol.2005.08.010

Al-Shammery, K. A. (2011). Plant pollen as an alternative food source for rearing Euseius scutalis (Acari: Phytoseiidae) in Hail, Saudi Arabia. J. Entomol. 8, 365-374. doi: 10.3923/je.2011.365.374

Andorno, A. V., and López, S. N. (2014). Biological control of Myzus persicae (Hemiptera: Aphididae) through banker plant system in protected crops. Biol. Control 78, 9-14. doi: 10.1016/j.biocontrol.2014. 07.003

Ankersmit, G. W., Dijkman, H., Keuning, N. J., Mertens, H., Sins, A., and Tacoma, H. M. (1986). Episyrphus balteatus as a predator of the aphid Sitobion avenae on winter wheat. Entomol. Exp. Appl. 42, 271-277. doi: 10.1111/j.1570-7458.1986.tb01032.x

Arijs, Y., and De Clercq, P. (2001). Rearing Orius laevigatus on cysts of the brine shrimp Artemia franciscana. Biol. Control 21, 79-83. doi: 10.1006/bcon.2000.0910

Arijs, Y., and De Clercq, P. (2004). Liver-based artificial diets for the production of Orius laevigatus. Biocontrol 49, 505-516. doi: 10.1023/B:BICO.0000036440.02590.fa

Armando, P., and Yates, R. (2011). Orius Banker/Companion Plants to Combat Thrips Population Spikes. Available online at: http://www.ggspro.com/new/ pdfs/Orius-Banker.pdf (accessed June 2020).

Arnó, J., Ariño, J., Español, R., Marti, M., and Alomar, O. (2000). Conservation of Macrolophus caliginosus Wagner (Het. Miridae) in commercial greenhouses during tomato crop-free periods. Conservation of Macrolophus caliginosus Wagner (Het. Miridae) in commercial greenhouses during tomato crop-free periods 23, 241-246. Bull. OILB/SROP 23, 241-246.

Arnó, J., Castañé, C., Riudavets, J., and Gabarra, R. (2010). Risk of damage to tomato crops by the generalist zoophytophagous predator Nesidiocoris tenuis (Reuter) (Hemiptera: Miridae). B. Entomol. Res. 100, 105-15. doi: $10.1017 /$ S0007485309006841

Arnó, J., and Gabarra, R. (2011). Side effects of selected insecticides on the Tuta absoluta (Lepidoptera: Gelechiidae) predators Macrolophus pygmaeus and Nesidiocoris tenuis (Hemiptera: Miridae). J. Pest Sci. 84, 513-520. doi: 10.1007/s10340-011-0384-z

Arvaniti, K. A., Fantinou, A. A., and Perdikis, D. C. (2018). Plant and supplementary food sources effect the development of Dicyphus errans (Hemiptera: Miridae). Appl. Entomol. Zool. 53, 493-499. doi: 10.1007/s13355-018-0579-3

Attia, A. R., El Arnaouty, S. A., Afifi, A. I., and Abd Alla, A. E. (2011). Development and fecundity of the coccinellid predator, Cryptolaemus montrouzieri mulsant on different types of preys. Egypt. J. Biol. Pest Co. 21, 283-289.

Audenaert, J., Vangansbeke, D., Verhoeven, R., De Clercq, P., Tirry, L., and Gobin, G. (2013). "Artificial diet to support predatory mites Amblyseius swirskii and 
Amblydromalus limonicus," in Fourth Meeting of the IOBC Working Group Integrated Control of Plant-Feeding Mites (Paphos), 9-12.

Avery, P. B., Kumar, V., Xiao, Y., Powell, C. A., McKenzie, C. L., and Osborne, L. S. (2014). Selecting an ornamental pepper banker plant for Amblyseius swirskii in floriculture crops. Arthropod Plant Inte. 8, 49-56. doi: 10.1007/s11829-013-9283-y

Azzouz, H., Giordanengo, P., Wäckers, F. L., and Kaiser, L. (2004). Effects of feeding frequency and sugar concentration on behavior and longevity of the adult aphid parasitoid: Aphidius ervi (Haliday) (Hymenoptera: Braconidae). Biol. Control 31, 445-452. doi: 10.1016/j.biocontrol.2004.07.013

Bakker, F. M., and Sabelis, M. W. (1989). How larvae of Thrips tabaci reduce the attack success of phytoseiid predators. Entomol. Exp. Appl. 50, 47-51. doi: 10.1111/j.1570-7458.1989.tb02313.x

Barbosa, M. F., and de Moraes, G. J. (2015). Evaluation of astigmatid mites as factitious food for rearing four predaceous phytoseiid mites (Acari: Astigmatina; Phytoseiidae). Biol. Control 91, 22-26. doi: 10.1016/j.biocontrol.2015.06.010

Beckman, N., and Hurd, L. E. (2003). Pollen feeding and fitness in praying mantids: the vegetarian side of a tritrophic predator. Environ. Entomol. 32, 881-885. doi: 10.1603/0046-225X-32.4.881

Begum, M., Gurr, G. M., Wratten, S. D., Hedberg, P. R., and Nicol, H. I. (2006). Using selective food plants to maximize biological control of vineyard pests. J. Appl. Ecol. 43, 547-554. doi: 10.1111/j.1365-2664.2006.01168.x

Beltrà, A., Calabuig, A., Navarro-Campos, C., Ramírez-Soria, M. J., Soto, A., Garcia-Marí, F., et al. (2017). Provisioning of food supplements enhances the conservation of phytoseiid mites in citrus. Biol. Control 115, 18-22. doi: 10.1016/j.biocontrol.2017. 09.007

Bennison, J., Pope, T., and Maulden, K. (2011). The potential use of flowering alyssum as a 'banker' plant to support the establishment of Orius laevigatus in everbearer strawberry for improved biological control of western flower thrips. IOBC/WPRS Bull. 68, 15-18.

Bennison, J. A. (1992). Biological control of aphids on cucumbers use of open rearing systems or 'banker plants' to aid establishment of Aphidius matricariae and Aphidoletes aphidimyza. Med. Fac. Landbouww. Univ. Gent. 57, 457-466.

Bennison, J. A., and Corless, S. P. (1993). Biological control of aphids on cucumbers: further development of open rearing units or "banker plants" to aid establishment of aphid natural enemies. IOBC/WPRS Bull. 16, 5-8.

Berkvens, N., Bonte, J., Berkvens, D., Deforce, K., Tirry, L., and De Clercq, P. (2007). Pollen as an alternative food for Harmonia axyridis. Biocontrol 53, 201-210. doi: 10.1007/s10526-007-9128-7

Bermúdez, P., Vargas, R., Cardemil, A., and López, E. (2010). Effect of pollen from different plant species on development of Typhlodromus pyri (Sheuten) (Acari: Phytoseiidae). Chil. J. Agric. Res. 70, 408-416. doi: $10.4067 /$ S0718-58392010000300008

Bernardo, A. M. G., de Oliveira, C. M., Oliveira, R. A., Vacacela, H. E., Venzon, M., Pallini, A., et al. (2017). Performance of Orius insidiosus on alternative foods. J. Appl. Entomol. 141, 702-707. doi: 10.1111/jen.12390

Berndt, L. A., and Wratten, S. D. (2005). Effects of alyssum flowers on the longevity, fecundity, and sex ratio of the leafroller parasitoid Dolichogenidea tasmanica. Biol. Control 32, 65-69. doi: 10.1016/j.biocontrol.2004.07.014

Bezerra, C. E. S., Amaral, B. B., and Souza, B. (2017). Rearing Chrysoperla externa larvae on artificial diets. Neotro. Entomol. 46, 93-99. doi: 10.1007/s13744-016-0427-5

Biondi, A., Zappalà, L., Di Mauro, A., Garzia, G. T., Russo, A., Desneux, N., et al. (2016). Can alternative host plant and prey affect phytophagy and biological control by the zoophytophagous mirid Nesidiocoris tenuis? BioControl 61, 79-90. doi: 10.1007/s10526-015-9700-5

Birkhofer, K., Wise, D. H., and Scheu, S. (2008). Subsidy from the detrital food web, but not microhabitat complexity, affects the role of generalist predators in an aboveground herbivore food web. Oikos 117, 494-500. doi: 10.1111/j.0030-1299.2008.16361.x

Blackman, R. L. (1967). The effects of different aphid foods on Adalia bipunctata L. and Coccinella 7-punctata L. Ann. Appl. Biol. 59, 207-219. doi: 10.1111/j.1744-7348.1967.tb04429.x

Bloemhard, C., Catalá L., Gerards, B., Shinde, A., Messelink, G., van der Salm, C., et al. (2018). Green Challenges: Waar Blijft de Trips? Available online at: https:// edepot.wur.nl/443879 (accessed June 2020).
Blümel, S., and Hausdorf, H. (1996). Greenhouse trials for the control of aphids on cut-roses with the chalcid Aphelinus abdominalis Dalm (Aphelinidae, Hymen.). Anzeiger Schädlingskunde Pflanzenschutz Umweltschutz 69, 64-69. doi: $10.1007 / \mathrm{BF} 01906278$

Bolckmans, K. J. F., and Tetteroo, A. N. M. (2002). Biological pest control in eggplants in the Netherlands. IOBC/WPRS Bull. 25, 25-28.

Boll, R., Geria, A., Marconi, A., Migliore, O., and Salles, M. (2001a). Des plantesrelais contre les pucerons en culture de concombre. Rev. Hortic. 426, 37-42.

Boll, R., Geria, A., Marconi, A., Migliore, O., Salles, M., and Fauvergue, X. (2001b). Contre les pucerons en serres de concombre. Les plantes-relais: une solution biologique? Phytoma 536, 40-44.

Bolter, C. J., Dicke, M., Van Loon, J. J., Visser, J. H., and Posthumus, M. A. (1997). Attraction of colorado potato beetle to herbivore-damaged plants during herbivory and after its termination. J. Chem. Ecol. 23, 1003-1023. doi: 10.1023/B:JOEC.0000006385.70652.5e

Bonte, J., Van de Walle, A., Conlong, D., and De Clercq, P. (2017). Eggs of Ephestia kuehniella and Ceratitis capitata, and motile stages of the astigmatid mites Tyrophagus putrescentiae and Carpoglyphus lactis as factitious foods for Orius spp. Insect Sci. 24, 613-622. doi: 10.1111/1744-7917.12293

Bonte, J., Vangansbeke, D., Maes, S., Bonte, M., Conlong, D., De Clercq, P., et al. (2012). Moisture source and diet affect development and reproduction of Orius thripoborus and Orius naivashae, two predatory anthocorids from southern Africa. J. Insect Sci. 12, 1-16. doi: 10.1673/031.012.0101

Bonte, M., and De Clercq, P. (2008). Developmental and reproductive fitness of Orius laevigatus (Hemiptera: Anthocoridae) reared on factitious and artificial diets. J. Econ. Entomol. 101, 1127-1133. doi: 10.1603/0022-0493(2008)1011127:DARFOO2.0.CO;2

Bottrell, D. G., Barbosa, P., and Gould, F. (1998). Manipulating natural enemies by plant variety selection and modification: a realistic strategy? Annu. Rev. Entomol. 43, 347-367. doi: 10.1146/annurev.ento.43.1.347

Bouras, S. L., and Papadoulis, G. T. (2005). Influence of selected fruit tree pollen on life history of Euseius stipulatus (Acari: Phytoseiidae). Exp. Appl. Acarol. 36, 1-14. doi: 10.1007/s10493-005-2381-5

Bravenboer, L., and Dosse, G. (1962). Phytoseiulus riegeli dosse als prädator einiger schadmilben aus der Tetranychus urticae-Gruppe. Entomol. Exp. Appl. 5, 291-304. doi: 10.1111/j.1570-7458.1962.tb00594.x

Brenard, N., Sluydts, V., Christianen, E., Bosmans, L., De Bruyn, L., Moerkens, R., et al. (2019). Biweekly supplementation with Artemia spp. cysts allows efficient population establishment by macrolophus pygmaeus in sweet pepper. Entomol. Exp. Appl. 167, 406-414. doi: 10.1111/eea.12776

Brenard, N., Sluydts, V., De Bruyn, L., Leirs, H., and Moerkens, R. (2018). Food supplementation to optimize inoculative release of the predatory bug Macrolophus pygmaeus in sweet pepper. Entomol. Exp. Appl. 166, 574-582. doi: 10.1111/eea.12704

Bresch, C., Carlesso, L., Suay, R., Van Oudenhove, L., Touzeau, S., Fatnassi, H., et al. (2018). In search of artificial domatia for predatory mites. Biocontrol Sci. Technol. 29, 131-148. doi: 10.1080/09583157.2018.1540030

Bresch, C., Ottenwalder, L., Poncet, C., and Parolin, P. (2014). Tobacco as banker plant for Macrolophus pygmaeus to control Trialeurodes vaporariorum in tomato crops. Uni. J. Agric. Res. 2, 297-304. doi: 10.13189/ujar.2014. 020803

Bresch, C., Ruiz, G., Poncet, C., and Parolin, P. (2015). Predatory mites Neoseiulus californicus and Phytoseiulus persimilis chose plants with domatia. J. Mediterr. Ecol. 13, 13-20.

Bribosia, E., Bylemans, D., Huysmans, S., Schweitzer, P., Migon, M., and Van Impe, G. (2005). The use of common elder Sambucus nigra to promote aphidophagous syrphids in apple orchards. Commun. Agric. Appl. Biol. Sci. $70,527-38$

Broufas, G. D., and Koveos, D. S. (2000). Effect of different pollens on development, survivorship and reproduction of Euseius finlandicus (Acari: Phytoseiidae). Environ. Entomol. 29, 743-749. doi: 10.1603/0046-225X-29.4.743

Brownbridge, M., Buitenhuis, R., Murphy, G., Waite, M., and Scott-Dupree, C. (2013). "Banker plants, trap crops and other bioprotection developments in Canadian greenhouse floriculture," in Proceedings of the 4th International Symposium on Biological Control of Arthropods (Pucón) 133-136.

Bueno, V. H., Silva, A. R., Carvalho, L. M., and Moura, N. (2009). Control of thrips with Orius insidiosus in greenhouse cut roses: use of a banker plant improves the performance of the predator. IOBC/WPRS Bull. 49, 183-187. 
Bueno, V. H. P., Montes, F. C., Sampaio, M. V., Calixto, A. M., and Van Lenteren, J. C. (2018). Performance of immatures of three neotropical miridae at five different temperatures, reared on Ephestia kuehniella eggs on tobacco plants. Bull. Insectol. 71, 77-87.

Buitenhuis, R., Glemser, E., and Brommit, A. (2014). Practical placement improves the performance of slow release sachets of Neoseiulus cucumeris. Biocontrol. Sci. Technol. 24, 1153-1166. doi: 10.1080/09583157.2014.930726

Buitenhuis, R., Murphy, G., Shipp, L., and Scott-Dupree, C. (2015). Amblyseius swirskii in greenhouse production systems: a floricultural perspective. Exp. Appl. Acarol. 65, 451-464. doi: 10.1007/s10493-014-9869-9

Buitenhuis, R., Shipp, L., and Scott-Dupree, C. (2010). Dispersal of Amblyseius swirskii Athias-Henriot (Acari: Phytoseiidae) on potted greenhouse chrysanthemum. Biol. Control 52, 110-114. doi: 10.1016/j.biocontrol.2009.10.007

Buxton, J. H. (1989). Tyrophagus longior (Gervais) (Acarina; Acaridae) as a pest of ornamentals grown under protection. Plant pathol. 38, 447-448. doi: 10.1111/j.1365-3059.1989.tb02167.x

Callebaut, B., Van Baal, E., Vandekerkhove, B., Bolckmans, K., and De Clercq, P. (2004). A fecundity test for assessing the quality of Macrolophus caliginosus reared on artificial diets. Parasitica 60, 9-14.

Calvert, D. J., and Huffaker, C. B. (1974). Predator [Metaseiulus occidentalis]-Prey [Pronematus spp.] interactions under sulfur and cattail pollen applications in a noncommercial vineyard. Entomophaga 19, 361-369. doi: 10.1007/BF02371062

Calvert, F., Hollingsworth, R. G., Wall, M., and Follett, P. A. (2019). Survey of flowering plants in Hawaii as potential banker plants of anthocorid predators for thrips control. J. Asia Pac. Entomol. 22, 638-644. doi: 10.1016/j.aspen.2019.05.001

Cameron, P. J., Powell, W., and Loxdale, H. D. (1984). Reservoirs for Aphidius ervi Haliday (Hymenoptera: Aphidiidae), a polyphagous parasitoid of cereal aphids (Hemiptera: Aphididae). B. Entomol. Res. 74, 647-656. doi: $10.1017 /$ S0007485300014024

Campbell, A. J., Biesmeijer, J. C., Varma, V., and Wäckers, F. L. (2012). Realising multiple ecosystem services based on the response of three beneficial insect groups to floral traits and trait diversity. Basic Appl. Ecol. 13, 363-370. doi: 10.1016/j.baae.2012.04.003

Campos, M. G., Bogdanov, S., de Almeida-Muradian, L. B., Szczesna, T., Mancebo, Y., Frigerio, C., et al. (2008). Pollen composition and standardisation of analytical methods. J. Apic. Res. 47, 154-161. doi: 10.1080/00218839.2008.11101443

Cano, M., Vila, E., Janssen, D., Bretones, G., Salvador, E., Lara, L., et al. (2009). Selection of refuges for Nesidiocoris tenuis (Het.: Miridae) and Orius laevigatus (Het.: Anthocoridae): virus reservoir risk assessment. IOBC/WPRS Bull. 49, 281-286.

Cano, M., Vila, E., Salvador, E., Janssen, D., Lara, L., and Tellez, M. M. (2012). Use of Mentha suaveolens Ehrh and Ocimum basilicum Linnaeus as refuge plants to advance the installation of Orius laevigatus Fieber (Hemiptera: anthocoridae) on pepper crop. Bol. San. Veg. Plagas 38, 311-319.

Carrillo, D., Pena, J. E., Hoy, M. A., and Frank, J. H. (2010). Development and reproduction of Amblyseius largoensis (Acari: Phytoseiidae) feeding on pollen, Raoiella indica (Acari: Tenuipalpidae), and other microarthropods inhabiting coconuts in Florida, USA. Exp. Appl. Acarol. 52, 119-129. doi: 10.1007/s10493-010-9360-1

Castagnoli, M. (1989). Biology and possibilities of mass rearing of Amblyseius cucumeris (Oud.) (Acarina: Phytoseiidae) using Dermatophagoides farinae Hughes (Acarina: Pyroglyphidae) as prey. Redia 72, 389-401.

Castagnoli, M., and Liguori, M. (1986). Development and oviposition times of Typhlodromus exhilaratus Ragusa (Acarina: Phytoseiidae) reared on various types of food. Redia 69, 361-368.

Castagnoli, M., and Liguori, M. (1991). "Laboratory observations on duration of copulation and egg production of three phytoseiid species fed on pollen," in The Acari, ed R. Schuster et al. (Dordrecht: Springer), 231-239. doi: 10.1007/978-94-011-3102-5_15

Castagnoli, M., and Simoni, S. (1999). Effect of long-term feeding history on functional and numerical response of Neoseiulus californicus (Acari: Phytoseiidae). Exp. Appl. Acarol. 23, 217-234. doi: 10.1023/A:1006066930638

Castañé, C., Alomar, O., and Riudavets, J. (2003). Potential risk of damage to zucchinis caused by mirid bugs. IOBC/WPRS Bull. 26, 135-138.
Castañé, C., Arnó, J., Gabarra, R., and Alomar, O. (2011). Plant damage to vegetable crops by zoophytophagous mirid predators. Biol. Control 59, 22-29. doi: 10.1016/j.biocontrol.2011.03.007

Castañé, C., Quero, R., and Riudavets, J. (2006). The brine shrimp Artemia sp. as alternative prey for rearing the predatory bug Macrolophus caliginosus. Biol. Control 38, 405-412. doi: 10.1016/j.biocontrol.2006.04.011

Castañé, C., and Zapata, R. (2005). Rearing the predatory bug Macrolophus caliginosus on a meat-based diet. Biol. Control 34, 66-72. doi: 10.1016/j.biocontrol.2005.04.002

Ceballos, M., Duarte, L., Baños, H. L., Sánchez, A., and Chico, R. (2011). Rearing of Diaeretiella rapae McIntosh in banker plants system. Rev. Prot. Veg. $26,129-130$

Chau, A., and Mackauer, M. (2001). Preference of the aphid parasitoid Monoctonus paulensis (Hymenoptera: Braconidae, Aphidiinae) for different aphid species: female choice and offspring survival. Biol. Control 20, 30-38. doi: 10.1006/bcon.2000.0881

Chitturi, A., Riley, D. G., and Joost, P. H. (2006). Effect of pine pollen on settling behavior of Frankliniella occidentalis and Frankliniella fusca (Thysanoptera: Thripidae) on tomato and peanut. Environ. Entomol. 35, 1396-1403. doi: 10.1093/ee/35.5.1396

Chyzik, R., Klein, M., and Ben-Dov, Y. (1995). Reproduction and survival of the predatory bug Orius albidipennis on various arthropod prey. Entomol. Exp. Appl. 75, 27-31. doi: 10.1111/j.1570-7458.1995.tb01906.x

Cisneros, J., and Rosenheim, J. A. Y. (1997). Ontogenetic change of prey preference in the generalist predator Zelus renardii and its influence on predator-predator interactions. Ecol. Entomol. 22, 399-407. doi: 10.1046/j.1365-2311.1997.00065.x

Cloutier, C., and Johnson, S. G. (1993). Interaction between life stages in a phytoseiid predator: western flower thrips prey killed by adults as food for protonymphs of Amblyseius cucumeris. Exp. Appl. Acarol. 17, 441-449. doi: 10.1007/BF00120502

Cocuzza, G. E., De Clercq, P., Van De Veire, M., De Cock, A., Degheele, D., and Vacante, V. (1997). Reproduction of Orius laevigatus and Orius albidipennis on pollen and Ephestia kuehniella eggs. Entomol. Exp. Appl. 82, 101-104. doi: 10.1046/j.1570-7458.1997.00118.x

Cohen, A. C. (1985). Simple method for rearing the insect predator Geocoris punctipes (Heteroptera: Lygaeidae) on a meat diet. J. Econ. Entomol. 78, 1173-1175. doi: 10.1093/jee/78.5.1173

Coll, M. (1998). "Living and feeding on plants in predatory Heteroptera," in Predatory Heteroptera in Agroecosystems: their Ecology and Use in Biological Control, eds M. Coll and J. R. Ruberson (Lanham, MA: Thomas Say Publications in Entomology: Proceedings Entomological Society of America), 89-129.

Coll, M., and Guershon, M. (2002). Omnivory in terrestrial arthropods: mixing plant and prey diets. Annu. Rev. Entomol. 47, 267-297. doi: 10.1146/annurev.ento.47.091201.145209

Coll, M., and Izraylevich, S. (1997). When predators also feed on plants: effects of competition and plant quality on omnivore-prey population dynamics. Ann. Entomol. Soc. Am. 90, 155-161. doi: 10.1093/aesa/90.2.155

Colley, M. R., and Luna, J. M. (2000). Relative attractiveness of potential beneficial insectary plants to aphidophagous hoverflies (Diptera: Syrphidae). Environ. Entomol. 29, 1054-1059. doi: 10.1603/0046-225X-29.5.1054

Collier, T., and Van Steenwyk, R. (2004). A critical evaluation of augmentative biological control. Biol. Control 31, 245-256. doi: 10.1016/j.biocontrol.2004.05.001

Constant, B., Grenier, S., and Bonnot, G. (1996). Artificial substrate for egg laying and embryonic development by the predatory bug Macrolophus caliginosus (Heteroptera: Miridae). Biol. Control 7, 140-147. doi: 10.1006/bcon.1996.0077

Conte, L. (1998). The banker plant technique for the biological control of Aphis gossypii on cucumber Cucumis sativus L. Inf. Agrar. 54, 71-75.

Corey, D., Kambhampati, S., and Wilde, G. (1998). Electrophoretic analysis of Orius insidiosus (Hemiptera: Anthocoridae) feeding habits in field corn. J. Kans. Entomol. Soc. 71, 11-17.

Cortesero, A. M., Stapel, J. O., and Lewis, W. J. (2000). Understanding and manipulating plant attributes to enhance biological control. Biol. Control 17, 35-49. doi: 10.1006/bcon.1999.0777

Coyle, D. R., Clark, K. E., Raffa, K. F., and Johnson, S. N. (2011). Prior host feeding experience influences ovipositional but not feeding preference 
in a polyphagous insect herbivore. Entomol. Exp. Appl. 138, 137-145. doi: $10.1111 /$ j.1570-7458.2010.01083.x

Crawley, M. J. (1975). The numerical responses of insect predators to changes in prey density. J. Anim. Ecol. 44, 877-892. doi: 10.2307/3725

Crum, D. A., Weiser, L. A., and Stamp, N. E. (1998). Effects of prey scarcity and plant material as a dietary supplement on an insect predator. Oikos 81, 549-557. doi: $10.2307 / 3546775$

Czaikowska, B., Vrie, M., and Kropczynska, D. (1988). Mites of the genus Tyrophagus as pests of ornamentals in greenhouses. Mites of the genus Tyrophagus as pests of ornamentals in greenhouses. Med. Fac. Landbouww. Univ. Gent. 53, 799-809.

Dafni, A. (1992). Pollination Ecology: a Practical Approach. Oxford: Oxford University Press.

Day, S., Beyer, R., Mercer, A., and Ogden, S. (1990). The nutrient composition of honeybee-collected pollen in Otago, New Zealand. J. Apic. Res. 29, 138-146. doi: 10.1080/00218839.1990.11101210

De Bach, P. (1964). Biological Control of Insect Pests and Weeds. Biological Control of Insect Pests and Weeds. London: Chapman \& Hall Ltd.

De Clercq, P., Arijs, Y., Van Meir, T., Van Stappen, G., Sorgeloos, P., Dewettinck, K., et al. (2005a). Nutritional value of brine shrimp cysts as a factitious food for Orius laevigatus (Heteroptera: Anthocoridae). Biocontrol. Sci. Technol. 15, 467-479. doi: 10.1080/09583150500086706

De Clercq, P., Bonte, M., Van Speybroeck, K., Bolckmans, K., and Deforce, K. (2005b). Development and reproduction of Adalia bipunctata (Coleoptera: Coccinellidae) on eggs of Ephestia kuehniella (Lepidoptera: Phycitidae) and pollen. Pest Manag. Sci. Formerly Pestic. Sci. 61, 1129-1132. doi: $10.1002 /$ ps.1111

De Clercq, P., and Degheele, D. (1992). Influence of feeding interval on reproduction and longevity of Podisus sagitta (Het.: Pentatomidae). Entomophaga 37, 583-590. doi: 10.1007/BF02372328

De Figueiredo, E. S., Massaro, M., do Carmo, S., and de Moraes, G. J. (2018). Rearing system for the predatory phytoseiid Euseius concordis (Acari: Phytoseiidae). Exp. Appl. Acarol. 74, 13-23. doi: 10.1007/s10493-018-0212-8

De Moraes, C. M., Mescher, M. C., and Tumlinson, J. H. (2001). Caterpillarinduced nocturnal plant volatiles repel conspecific females. Nature 410, 577-580. doi: 10.1038/35069058

Delgado, M. (1997). La volonté de produire plus propre. Cult. Légumière/ Hors Série Environ. Juin 22-23.

Delisle, J. F., Brodeur, J., and Shipp, L. (2015a). Evaluation of various types of supplemental food for two species of predatory mites, Amblyseius swirskii and Neoseiulus cucumeris (Acari: Phytoseiidae). Exp. Appl. Acarol. 65, 483-494. doi: 10.1007/s10493-014-9862-3

Delisle, J. F., Shipp, L., and Brodeur, J. (2015b). Apple pollen as a supplemental food source for the control of western flower thrips by two predatory mites, Amblyseius swirskii and Neoseiulus cucumeris (Acari: Phytoseiidae), on potted chrysanthemum. Exp. Appl. Acarol. 65, 495-509. doi: 10.1007/s10493-014-9863-2

Desneux, N., and Ramirez-Romero, R. (2009). Plant characteristics mediated by growing conditions can impact parasitoid's ability to attack host aphids in winter canola. J. Pest Sci. 82, 335-342. doi: 10.1007/s10340-009-0258-9

Dobson, H. E., and Bergström, G. (2000). The ecology and evolution of pollen odors. Plant Syst. Evol. 222, 63-87. doi: 10.1007/BF00984096

Dosse, G. (1961). Über die Bedeutung der Pollennahrung für Typhlodromus (T) pyri Scheuten (= Tiliae Oud.) (Acari, Phytoseiidae). Entomol. Exp. App. 4, 191-195. doi: 10.1111/j.1570-7458.1961.tb02134.x

Doutt, R. L. (1951). Biological control of mealybugs infesting commercial greenhouse gardenias. J. Econ. Entomol. 44, 37-40. doi: 10.1093/jee/44.1.37

Duarte, M. V. A., Venzon, M., Bittencourt, M. C., de, S. Bittencourt, Rodriguez-Cruz, F. A., Pallini, A., et al. (2015). Alternative food promotes broad mite control on chilli pepper plants. Biocontrol 60, 817-825. doi: 10.1007/s10526-015-9688-x

Duso, C., and Camporese, P. (1991). Developmental times and oviposition rates of predatory mites Typhlodromus pyri and Amblyseius andersoni (Acari: Phytoseiidae) reared on different foods. Exp. Appl. Acarol. 13, 117-128. doi: 10.1007/BF01193662

El-Husseiniak, M. O. N. I. R., and Sermann, H. (1992). First successful mass rearing of anthocorids (Heteroptera) on the acarid mould mite, Tyrophagus putrescentiae Schr. as new alternative prey. Beit. Entomol. 42:207.
Elliot, S. M., Sabelis, M. W., Janssen, A., Der Geest, L. P. S., Beerling, E. A. M., and Fransen, J. J. (2000). Can plants use entomopathogens as bodyguards? Ecol. Lett. 3, 228-235. doi: 10.1046/j.1461-0248.2000.00137.x

Emmert, C. J., Mizell, R. F., Andersen, P. C., Frank, J. H., and Stimac, J. L. (2008). Diet effects on intrinsic rate of increase and rearing of Proprioseiopsis asetus (Acari: Phytoseiidae). Ann. Entomol. Soc. Am. 101, 1033-1040. doi: 10.1603/0013-8746-101.6.1033

Engel, R. V., and Ohnesorge, B. (1994). Die rolle von ersatznahrung und mikroklima im system Typhlodromus pyri Scheuten (Acari, Phytoseiidae) - Panonychus ulmi Koch (Acari, Tetranychidae) auf weinreben I. Untersuchungen im labor. J. Appl. Entomol. 118, 129-150. doi: 10.1111/j.1439-0418.1994.tb00788.x

Englert, W. D., and Maixner, M. (1988). Rearing of Typhlodromus pyri scheuten in the laboratory and effects of pesticides on mortality and fecundity of this mite. Nachrichtenblatt des Deutschen Pflanzenschutzdienstes. 40, 121-124.

English-Loeb, G., Norton, A. P., Gadoury, D. M., Seem, R. C., and Wilcox, W. F. (1999). Control of powdery mildew in wild and cultivated grapes by a tydeid mite. Biol. Control 14, 97-103. doi: 10.1006/bcon.1998.0681

Eubanks, M. D., and Denno, R. F. (1999). The ecological consequences of variation in plants and prey for an omnivorous insect. Ecology 80, 1253-1266. doi: 10.1890/0012-9658(1999)0801253:TECOVI2.0.CO;2

Eubanks, M. D., and Styrsky, J. D. (2005). "Effects of plant feeding on the performance of omnivorous predators," in Plant-Provided Food for Carnivorous Insects: a Protective Mutualism and its Applications, eds F. L. Wäckers, P. C. J. van Rijn, and J. Bruin (Cambridge: Cambridge University Press), 148-177.

Fadaei, E., Hakimitabar, M., Seiedy, M., and Sarraf Moaieri, H. (2018). Effects of different diets on biological parameters of the predatory mite Amblyseius swirskii (Acari: Phytoseiidae). Int. J. Acarol. 44, 341-346. doi: 10.1080/01647954.2018.1525428

Fan, Q. H., and Zhang, Z. Q. (2007). Tyrophagus (Acari: Astigmata: Acaridae). Fauna of New Zealand, 56. Manaaki Whenua Press, Lincoln, Canterbury, New Zealand, 291p.

Faraji, F., Janssen, A., and Sabelis, M. W. (2002a). The benefits of clustering eggs: the role of egg predation and larval cannibalism in a predatory mite. Oecologia 131, 20-26. doi: 10.1007/s00442-001-0846-8

Faraji, F., Janssen, A., and Sabelis, M. W. (2002b). Oviposition patterns in a predatory mite reduce the risk of egg predation caused by prey. Ecol. Entomol. 27, 660-664. doi: 10.1046/j.1365-2311.2002.00456.x

Fauvel, G. (1974). Sur l'alimentation pollinique d'un anthocoride predateur Orius (Heterorius) vicinus Rib. (Hemiptera). Ann. Zool. Ecol. Anim. 6, 245-258.

Fauvel, G., Malausa, J. C., and Kaspar, B. (1987). Laboratory studies on the main biological characteristics of Macrolophus caliginosus (Heteroptera: Miridae). Entomophaga 32, 529-543. doi: 10.1007/BF023 73522

Ferkovich, S. M., Venkatesan, T., Shapiro, J. P., and Carpenter, J. E. (2007). Presentation of artificial diet: effects of composition and size of prey and diet domes on egg production by Orius insidiosus (Heteroptera: Anthocoridae). Fla. Entomol. 90, 502-508. doi: 10.1653/0015-4040(2007)90502:POADEO2.0.CO;2

Fernández-Caldas, E., Puerta, L., and Caraballo, L. (2014). "Mites and allergy," in History of Allergy 100 (Berlin; Munich: Karger Publishers, Bergmann and Ring), 234-242. doi: 10.1159/000358860

Ferragut, F., Garcia-Marí, F., Costa-Comelles, J., and Laborda, R. (1987). Influence of food and temperature on development and oviposition of Euseius stipulatus and Typhlodromus phialatus (Acari: Phytoseiidae). Exp. Appl. Acarol. 3, 317-329. doi: 10.1007/BF01193168

Ferragut, F., and González-Zamora, J. E. (1994). Diagnóstico y distribución de las especies de Orius Wolff 1811, peninsulares (Heteroptera, Anthocoridae). Bol. San. Veg. Plagas, 20, 89-101.

Ferreira, C. T., Krug, C., and Moraes, G. J. D. (2020). Effect of pollen of different plant species on the oviposition of two phytoseiid mites (Acari: Phytoseiidae) commonly found in citrus orchards in the Brazilian Amazonia. Acarologia 60, 22-29. doi: 10.24349/acarologia/20204360

Ferreira, J. A., Cunha, D. F., Pallini, A., Sabelis, M. W., and Janssen, A. (2011). Leaf domatia reduce intraguild predation among predatory mites. Ecol. Entomol. 36, 435-441. doi: 10.1111/j.1365-2311.2011.01286.x

Ferreira, J. A., Eshuis, B., Janssen, A., and Sabelis, M. W. (2008). Domatia reduce larval cannibalism in predatory mites. Ecol. Entomol. 33, 374-379. doi: 10.1111/j.1365-2311.2007.00970.x 
Ferreira, J. A., Pallini, A., Oliveira, C. L., Sabelis, M. W., and Janssen, A. (2010). Leaf domatia do not affect population dynamics of the predatory mite Iphiseiodes zuluagai. Basic Appl. Ecol. 11, 144-152. doi: 10.1016/j.baae.2009.10.008

Ferrero, M., Ben Soussan, T., Brancaccio, L., and Maignet, P. (2016). "Testing a new predator installation method in protected cucumber crop in Spain," in 8 th Symposium of the European Association of Acarologists July, 11th-15th 2016, EURAAC Abstract Book (Valencia), 54.

Fischer S. (1997). Contre le puceron du cotonnier l'utilisation des plantes-relais. Des plantes-banques sous abris. Culture Légumière- Hors Série Environnement Juin, 17-19.

Fischer, S. (1993). Observation of a new pest of cucumber in western Switzerland, Tyrophagus neiswanderi Johnston \& Bruce (Acari, Acaridae). Rev. Suisse Vitic. Arboric. Hortic. 25, 103-104.

Fischer, S. (2003). "Efficacite comparee de quelques methodes d'implantation du predateur Macrolophus caliginosus," in Colloque International Tomate sous abri, Protection Integree - Agriculture Biologique, Avignon, France, eds L. Roche, M. Edin, V. Mathieu, and F. Laurens 17-18 et 19 septembre (Paris: Centre Technique Interprofessionnel des Fruits et Legumes), 96-101.

Fischer, S., and Leger, A. (1997). Lutte biologique contre les pucerons du concombre en serre au moyen de plantes banques. Rev. Suisse Vitic. Arboric. Hortic. 29, 119-126.

Fischer, S., and Terrettaz, C. (2003). Release strategies of the mirid macrolophus caliginosus in protected tomato crops. Rev. suisse Vitic Arboric. Hortic. 3, 191-196.

Flechtmann, C. H., and McMurtry, J. A. (1992). Studies on how phytoseiid mites feed on spider mites and pollen. Int. J. Acarol. 18, 157-162. doi: 10.1080/01647959208683946

Fouly, A. H. (1997). Effects of prey mites and pollen on the biology and life tables of Proprioseiopsis asetus (Chant) (Acari, Phytoseiidae). J. Appl. Entomol. 121, 435-439. doilink[10.1111/j.1439-0418.1997.tb01431.x]10.1111/j.14390418.1997.tb01431.x

Frank, S. D. (2010). Biological control of arthropod pests using banker plant systems: past progress and future directions. Biol. Control 52, 8-16. doi: 10.1016/j.biocontrol.2009.09.011

Fratoni, S., Duarte, M. V., Vangansbeke, D., Wäckers, F. L., Dicke, M., and Pekas, A. (2020). A bittersweet meal: the impact of sugar solutions and honeydew on the fitness of two predatory gall midges. Biol. Control 140:104098. doi: 10.1016/j.biocontrol.2019.104098

Freuler, J., Fischer, S., Mittaz, C., and Terrettaz, C. (2001). Rôle des plantes relais pour renforcer l'action de Diaeretiella rapae, principal parasitoïde du puceron cendré du chou. Rev. Suisse Vitic. Arboric. Hortic. 33, 329-335.

Freuler, J., Fischer, S., Mittaz, C., and Terrettaz, C. (2003). The role of banker plants in the enhancement of the action of Diaeretiella rapae (M'Intosh) (Hymenoptera, Aphidiinae) the primary parasitoid of the cabbage aphid Brevicoryne brassicae (L.). IOBC/WPRS Bull. 26, 277-299.

Fujinuma, M., Kainoh, Y., and Nemoto, H. (2010). Borago officinalis attracts the aphid parasitoid Aphidius colemani (Hymenoptera: Braconidae). Appl. Entomol. Zool. 45, 615-620. doi: 10.1303/aez.2010.615

Funao, T., and Yoshiyasu, Y. (1995). Development and fecundity of Orius sauteri (Poppius) (Hemiptera, Anthocoridae) reared on Aphis gossypii Glover and corn pollen. Jpn. J. Appl. Entomol. Z. 39, 84-85. doi: 10.1303/jjaez.39.84

Gan-Mor, S., Bechar, A., Ronen, B., Eisikowitch, D., and Vaknin, Y. (2003). Electrostatic pollen applicator development and tests for almond, kiwi, date, and pistachio - an overview. Appl. Eng. Agric. 19, 119-124. doi: 10.13031/2013.13099

Gan-Mor, S., Palevsky, E., and Ronen, B. (2011). A Device and a Method for Pollen Application for Enhancing Biological Control. U.S. Patent Application No. $12 / 984,462$.

Ghasemzadeh, M., and Gharekhani, G. (2019). Feasibilty of rearing of predatory bug Macrolophus pygmaeus rambur (Hemiptera: Miridae) using urmia lake artemia (Artemia urmiana Gunther) under laboratory conditions. J. Appl. Res. Plant Prot. 7, 1-17.

Gillespie, D., McGregor, R., Sanchez, J. A., VanLaerhoven, S. L., Quiring, D., Roitberg, B., et al. (2007). "An endemic omnivorous predator for control of greenhouse pests," in Biological Control: a Global Perspective (Trowbridge: CAB international Publishing, Cromwell Press) 128-135. doi: $10.1079 / 9781845932657.0128$
Gillespie, D. R., and McGregor, R. R. (2000). The functions of plant feeding in the omnivorous predator Dicyphus hesperus: water places limits on predation. Ecol. Entomol. 25, 380-386. doi: 10.1046/j.1365-2311.2000.00285.x

Gillespie, D. R., VanLaerhoven, S. L., McGregor, R. R., Chan, S., and Roitberg, B. D. (2012). Plant feeding in an omnivorous mirid, Dicyphus hesperus: why plant context matters. Psyche A J. Entomol. 2012:495805. doi: 10.1155/2012/495805

Gnanvossou, D., Hanna, R., Yaninek, J. S., and Toko, M. (2005). Comparative life history traits of three neotropical phytoseiid mites maintained on plant-based diets. Biol. Control 35, 32-39. doi: 10.1016/j.biocontrol.2005.05.013

Goh, H. G., Kim, J. H., and Han, M. W. (2001). Application of Aphidius colemani viereck for control of the aphid in greenhouse. J. Asia Pac. Entomol. 4, 171-174. doi: 10.1016/S1226-8615(08)60119-3

Goleva, I., Cadena, E. C. R., Ranabhat, N. B., Beckereit, C., and Zebitz, C. P. (2015). Dietary effects on body weight of predatory mites (Acari, Phytoseiidae). Exp. Appl. Acarol. 66, 541-553. doi: 10.1007/s10493-015-9920-5

Goleva, I., and Zebitz, C. P. W. (2013). Suitability of different pollen as alternative food for the predatory mite Amblyseius swirskii (Acari, Phytoseiidae). Exp. Appl. Acarol. 61, 259-283. doi: 10.1007/s10493-013-9700-z

Gomaa, W. O., and Agamy, E. A. (2002). Tyrophagus putrescentiae schr (Acari: Acarididae) as prey for rearing the predator Orius laevigatus (Fieber) (Hemiptera: Anthocoridae). Egypt. J. Biol. Pest Control 12, 91-93.

Goolsby, J. A., and Ciomperlik, M. A. (1999). Development of parasitoid inoculated seedling transplants for augmentative biological control of silverleaf whitefly (Homoptera: Aleyrodidae). Fla. Entomol. 82, 532-545. doi: $10.2307 / 3496471$

Goss, J. A. (1968). Development, physiology, and biochemistry of corn and wheat pollen. Bot. Rev. 34, 333-359. doi: 10.1007/BF02985391

Götte, E., and Sell, P. (2002). Biological pest management on greenhouse roses using open rearing units of Aphidoletes aphidimyza (Rond.) on cereal aphids as a key control strategy. Gesunde Pflanzen 54, 80-85. doi: 10.1046/j.1439-0345.2002.02016.x

Gould, H. J., Hussey, N. W., and Parr, W. J. (1969). "Large scale commercial control of Tetranychus urticae Koch on cucumbers by the predator Phytoseiulus persimilis," in A.-H. Proceedingd in the 2nd International Congress (Acar), 383-388.

Gourdine, J. S., McCutcheon, G. S., Simmons, A. M., and Leibee, G. L. (2003). Kale floral nectar and honey as food sources for enhancing longevity and parasitism of Diadegma insulare (Hymenoptera: Ichneumonidae), a parasitoid of the Diamondback moth, Plutella xylostella (Lepidoptera: Plutellidae). J. Agric. Urban Entomol. 20, 1-6.

Grenier, S., Guillaud, J., Delobel, B., and Bonnot, G. (1989). Nutrition et élevage du prédateur polyphage Macrolophus caliginosus [Heteroptera, Miridae] sur milieux artificiels. Entomophaga 34, 77-86. doi: 10.1007/BF02372590

Grevstad, F. S., and Klepetka, B. W. (1992). The influence of plant architecture on the foraging efficiencies of a suite of ladybird beetles feeding on aphids. Oecologia 92, 399-404. doi: 10.1007/BF00317466

Grosman, A. H., Bernardo, A. G., Bloemhard, C. M. J., Messelink, G. J., and Janssen, A. (2014). Alternative prey on the soil increases density of Amblyseius swirskii and Neoseiulus cucumeris on the plant and improves thrips control. IOBC/WPRS Bull. 102:84.

Grosman, G. M., and de Groot, E. (2011). Combined use of a mulch layer and the soil-dwelling predatory mite Macrocheles robustulus (Berlese) enhance the biological control of sciarids in potted plants. IOBC/WPRS Bull. 68, 51-54.

Grostal, R., and O'Dowd, D. J. (1994). Plants, mites and mutualism: leaf domatia and the abundance and reproduction of mites on Viburnum tinus (Caprifoliaceae). Oecologia 97, 308-315. doi: 10.1007/BF003 17319

Grout, T. G., and Richards, R. I. (1992). The dietary effect of windbreak pollens on longevity and fecundity of a predacious mite Euseius addoensis (Acari: Phytoseiidae) found in citrus orchards in South Africa. B. Entomol. Res. 82, 317-320. doi: 10.1017/S0007485300041080

Gugole Ottaviano, M. F. G., Cédola, C. V., Sánchez, N. E., and Greco, N. M. (2015). Conservation biological control in strawberry: effect of different pollen on development, survival, and reproduction of Neoseiulus californicus (Acari: Phytoseiidae). Exp. Appl. Acarol. 67, 507-521. doi: 10.1007/s10493-015-9971-7 Gurr, G. M. (2005). "Providing plant foods for natural enemies in farming systems: balancing practicalities and theory," in Plant Provided Food for Carnivorous 
Insects: A Protective Mutualism and its Applications (Cambridge: University Press), 341-347. doi: 10.1017/CBO9780511542220.012

Gurr, G. M., Wratten, S. D., Landis, D. A., and You, M. (2017). Habitat management to suppress pest populations: progress and prospects. Ann. Rev. Entomol. 62, 91-109. doi: 10.1146/annurev-ento-031616-035050

Hågvar, E. B., and Hofsvang, T. (1994). Colonization behaviour and parasitization by Ephedrus cerasicola (Hym., Aphidiidae) in choice studies with two species of plants and aphids. J. Appl. Entomol. 118, 23-30. doi: 10.1111/j.1439-0418.1994.tb00774.x

Hagen, K. S. (1986). "Ecosystem analysis: plant cultivars (HPR), entomophagous species and food supplements," in Interactions of Plant Resistance and Parasitoids and Predators of Insects, eds. D. J. Boethel and R. D. Eikenbary (New York, NY: Wiley), 151-197.

Hansen, L. S. (1983). Introduction of Aphidoletes aphidimyza (Rond.) (Diptera: Cecidomyiidae) from an open rearing unit for the control of aphids in glasshouses. SROP Bull. 6, 146-150.

Havelka, J., and Kindlmann, P. (1984). Optimal use of the "pest in first" method for controlling Tetranychus urticae Koch (Acarina, Tetranychidae) on glasshouse cucumbers through Phytoseiulus persimilis A.-H. (Acarina, Phytoseiidae). Z. Angew. Entomol. 98, 254-263. doi: 10.1111/j.1439-0418.1984.tb02710.x

Heil, M. (2015). Extrafloral nectar at the plant-insect interface: a spotlight on chemical ecology, phenotypic plasticity, and food webs. Annu. Rev. Entomol. 60, 213-232. doi: 10.1146/annurev-ento-010814-020753

Heimpel, G. E., and Jervis, M. A. (2005). "Does floral nectar improve biological control by parasitoids," in Plant-Provided Food for Carnivorous Insects: a Protective Mutualism and its Applications (Cambridge: Cambridge University Press), 267-304.

Hemerik, L., and Yano, E. (2012). Evaluating the banker plant system for biologically controlling the cotton aphid, Aphis gossypii, with larvae of the gall midge, Aphidoletes aphidimyza, with a mathematical model. Proc. Neth. Entomol. Soc. Meet. 23, 29-37.

Henry, L. M., Gillespie, D. R., and Roitberg, B. D. (2005). Does mother really know best? Oviposition preference reduces reproductive performance in the generalist parasitoid Aphidius ervi. Entomol. Exp. Appl. 116, 167-174. doi: 10.1111/j.1570-7458.2005.00318.x

Higashida, K., Yano, E., Nishikawa, S., Ono, S., Okuno, N., and Sakaguchi, T. (2016). Reproduction and oviposition selection by Aphidoletes aphidimyza (Diptera: Cecidomyiidae) on the banker plants with alternative prey aphids or crop plants with pest aphids. Appl. Entomol. Zool. 51, 445-456. doi: 10.1007/s13355-016-0420-9

Higashida, K., Yano, E., Toyonishi, H., Nakauchi, M., and Abe, J. (2017). Reproduction of Aphidoletes aphidimyza (Diptera: Cecidomyiidae) on a banker plant system of sorghum with Melanaphis sacchari (Hemiptera: Aphididae) and its oviposition selection between this system and eggplant with Aphis gossypii (Hemiptera: Aphididae). Appl. Entomol. Zool. 52, 295-303. doi: 10.1007/s13355-017-0477-0

Hilgers, J., Gruda, N., and Noga, G. (2016). Artemia sp. cysts as food alternative for Macrolophus pygmaeus, as evaluated under practical conditions. Gesunde Pflanzen 68, 135-143. doi: 10.1007/s10343-016-0372-6

Hoddle, M., Van Driesche, R., and Sanderson, J. (1997). Biological control of Bemisia argentifolii (Homoptera: Aleyrodidae) on poinsettia with inundative releases of Encarsia formosa (Hymenoptera: Aphelinidae): are higher release rates necessarily better? Biol. Contr. 10, 166-179. doi: 10.1006/bcon. 1997.0571

Hoddle, M. S., Van Driesche, R. G., Sanderson, J. P., and Minkenberg, O. P. J. M. (1998). Biological control of Bemisia argentifolii (Hemiptera: Aleyrodidae) on poinsettia with inundative releases of Eretmocerus eremicus (Hymenoptera: Aphelinidae): do release rates affect parasitism? B. Entomol. Res. 88, 47-58. doi: 10.1017/S0007485300041547

Hodek, I., and Honěk, A. (2013). Ecology of Coccinellidae, 54. Dordrecht: Springer Science+Business Media B.V., 464

Hodek, I., Ruzicka, Z., and Hodkova, M. (1978). Pollinivorie et aphidiphagie chez Coleomegilla maculata Lengi. Ann. Zool. Ecol. Anim. 10, 453-459.

Hodek, I., and Honěk, A. (1996). "Effectiveness and utilization," in Ecology of Coccinellidae, eds I. Hodek and A. Honěk (Dordrecht: Springer), 351-389. doi: 10.1007/978-94-017-1349-8_9

Hofsvang, T., and Hågvar, E. B. (1979). Different introduction methods of Ephedrus cerasicola starý to control Myzus persicae (Sulzer) in small paprika glasshouses. Z. Angew. Entomol. 88, 16-23. doi: 10.1111/j.1439-0418.1979.tb02472.x

Hogervorst, P. A., Wäckers, F. L., and Romeis, J. (2007). Detecting nutritional state and food source use in field-collected insects that synthesize honeydew oligosaccharides. Funct. Ecol. 21, 936-946. doi: 10.1111/j.1365-2435.2007.01297.x

Hogg, B. N., Bugg, R. L., and Daane, K. M. (2011). Attractiveness of common insectary and harvestable floral resources to beneficial insects. Biol. Control 56, 76-84. doi: 10.1016/j.biocontrol.2010.09.007

Holt, R. A., and Lawton, J. H. (1994). The ecological consequences of shared natural enemies. Annu. Rev. Ecol. Syst. 25, 495-520. doi: 10.1146/annurev.es.25.110194.002431

Holt, R. D. (1977). Predation, apparent competition, and the structure of prey communities. Theor. Popul. Biol. 12, 197-229. doi: 10.1016/0040-5809(77)90042-9

Holt, R. D., and Lawton, J. H. (1993). Apparent competition and enemyfree space in insect host-parasitoid communities. Am. Nat. 142, 623-645. doi: $10.1086 / 285561$

Hongo, T., and Obayashi, N. (1997). Use of diapause eggs of brine shrimp, Artemia salina (Linne) for artificial diet of coccinelid beetle, Harmonia axyridis (Pallas). Japan. J. Appl. Entomol. Zool. 41, 101-105. doi: 10.1303/jjaez.41.101

Hoogerbrugge, H., van Houten, Y., van Baal, E., and Bolckmans, K. (2008). Alternative food sources to enable establishment of Amblyseius swirskii (AthiasHenriot) on chrysanthemum without pest presence. IOBC/WPRS Bull. 32:79.

Hoogerbrugge, H., van Houten, Y. V., Knapp, M., and Bolckmans, K. (2011). Biological control of thrips and whitefly on strawberries with Amblydromalus limonicus and Amblyseius swirskii. IOBC/WPRS Bull. 68, 65-69.

Huang, N., Enkegaard, A., Osborne, L. S., Ramakers, P. M., Messelink, G. J., Pijnakker, J., et al. (2011). The banker plant method in biological control. Crit. Rev. Plant Sci. 30, 259-278. doi: 10.1080/07352689.2011.572055

Hulshof, J., Ketoja, E., and Vänninen, I. (2003). Life history characteristics of Frankliniella occidentalis on cucumber leaves with and without supplemental food. Entomol. Exp. Appl. 108, 19-32. doi: 10.1046/j.1570-7458.2003.00061.x

Husseini, M., Schumann, K., and Sermann, H. (1993). Rearing immature feeding stage of Orius majusculus Reut. (Het., Anthocoridae) on the acarid mite Tyrophagus putrescentiae Schr. as new alternative prey. J. Appl. Entomol. 116, 113-117. doi: 10.1111/j.1439-0418.1993.tb01176.x

Hussey, N. W., Parr, W. J., and Gould, H. J. (1965). Observations on the control of Tetranychus urticae koch on cucumbers by the predatory mite Phytoseiulus riegeli dosse. Entomol. Exp. Appl. 8, 271-281. doi: 10.1111/j.1570-7458.1965.tb00861.x

Hussey, N. W., Read, W. H., and Hesling, J. J. (1969). The Pests of Protected Cultivation. The Biology and Control of Glasshouse and Mushroom Pests. London: Edward Arnold Ltd.

Idris, A. B., and Grafius, E. (1995). Wildflowers as nectar sources for Diadegma insulare (Hymenoptera: Ichneumonidae), a parasitoid of diamondback moth (Lepidoptera: Yponomeutidae). Environ. Entomol. 24, 1726-1735. doi: 10.1093/ee/24.6.1726

Idris, A. B., and Grafius, E. (1996). Effects of wild and cultivated host plants on oviposition, survival, and development of diamondback moth (Lepidoptera: Plutellidae) and its parasitoid Diadegma insulare (Hymenoptera: Ichneumonidae). Environ. Entomol. 25, 825-833. doi: 10.1093/ee/25.4.825

Igarashi, K., and Nomura, M. (2013). Development and reproduction of geocoris varius (Hemiptera: Geocoridae) on two types of artificial diet. Appl. Entomol. Zool. 48, 403-407. doi: 10.1007/s13355-013-0185-3

Iglesias-Souto, J., Sánchez-Machín, I., Iraola, V., Poza, P., González, R., and Matheu, V. (2009). Oral mite anaphylaxis by Thyreophagus entomophagus in a child: a case report. Clin. Mol. Allergy 7:10. doi: 10.1186/1476-7961-7-10

Imura, T., and Kamikawa, S. (2012). Possibility of Tagetes patula L. for banker plants of Orius spp. Ann. Rep. Kansai Plant Prot. Soc. 54, 163-165. doi: $10.4165 /$ kapps. 54.163

Iriarte, J., and Castañé, C. (2001). Artificial rearing of Dicyphus tamaninii (Heteroptera: Miridae) on a meat-based diet. Biol. Control 22, 98-102. doi: 10.1006/bcon.2001.0951

Jacobson, R. J., and Croft, P. (1998). Strategies for the control of Aphis gossypii Glover (Hom.: Aphididae) with Aphidius colemani Viereck (Hym.: Braconidae) in protected cucumbers. Biocontrol. Sci. Technol. 8, 377-387. doi: 10.1080/09583159830180 
Jandricic, S. E., Dale, A. G., Bader, A., and Frank, S. D. (2014). The effect of banker plant species on the fitness of Aphidius colemani Viereck and its aphid host (Rhopalosiphum padi L.). Biol. Control 76, 28-35. doi: 10.1016/j.biocontrol.2014.04.007

Janmaat, L., Bloemhard, C., and Kleppe, R. (2014). Biodiversiteit Onder Glas. Voedsel Voor Luizenbestrijders. Available online at: https://www.louisbolk.org/ downloads/2819.pdf (accessed June 2020).

Janssen, A., and Sabelis, M. W. (2015). Alternative food and biological control by generalist predatory mites: the case of Amblyseius swirskii. Exp. Appl. Acarol. 65, 413-418. doi: 10.1007/s10493-015-9901-8

Ji, J., Zhang, Y. X., Lin, J. Z., Chen, X., Sun, L., and Saito, Y. (2015). Life histories of three predatory mites feeding upon Carpoglyphus lactis (Acari, Phytoseiidae; Carpoglyphidae). Syst. Appl. Acarol. 20, 491-496. doi: 10.11158/saa.20.5.5

Johanowicz, D. L., and Mitchell, E. R. (2000). Effects of sweet alyssum flowers on the longevity of the parasitoid wasps Cotesia marginiventris (Hymenoptera: Braconidae) and Diadegma insulare (Hymenoptera: Ichneumonidae). Fla. Entomol. 83, 41-47. doi: 10.2307/3496226

Kalberer, N. M., Turlings, T. C., and Rahier, M. (2001). Attraction of a leaf beetle (Oreina cacaliae) to damaged host plants. J. Chem. Ecol. 27, 647-661. doi: 10.1023/A:1010389500009

Karban, R., and Baldwin, I. T. (1997). Induced Responses to Herbivory. Chicago, IL: University of Chicago.

Karban, R., English-Loeb, G., Walker, M. A., and Thaler, J. (1995). Abundance of phytoseiid mites on vitis species: effects of leaf hairs, domatia, prey abundance and plant phylogeny. Exp. Appl. Acarol. 19, 189-197. doi: 10.1007/BF00130822

Kathiar, S. A., Hamad, B. S., and AlMarsoomy, M. D. (2015). Effects of different diet levels of Ephestia kuehniella eggs on life history parameters of Chrysoperla rufilabris (Neuroptera: Chrysopidae) under laboratory conditions. Mesop. Environ. J. 1, 1-7.

Kawashima, M., Adachi, I., and Toyama, M. (2006a). Artificial microstructure encouraging the colonization of the predacious mite, Neoseiulus californicus (McGregor) (Acari: Phytoseiidae). Appl. Entomol. Zool. 41, 633-639. doi: 10.1303/aez.2006.633

Kawashima, M., and Amano, H. (2006). Overwintering phenology of a predacious mite, Typhlodromus vulgaris (Acari: Phytoseiidae), on Japanese pear trees, observed with Phyto traps. Exp. Appl. Acarol. 39, 105-114. doi: $10.1007 /$ s10493-006-9002-9

Kawashima, M., and Jung, C. (2011). Effects of sheltered ground habitats on the overwintering potential of the predacious mite Neoseiulus californicus (Acari: Phytoseiidae) in apple orchards. Exp. Appl. Acarol. 55, 375-88. doi: 10.1007/s10493-011-9477-x

Kawashima, M., Kadono, F., Shiota, A., and Amano, H. (2006b). Can the population size of Neoseiulus californicus (McGregor) (Acari: Phytoseiidae) on Japanese pear trees be estimated by phyto traps attached to the twigs? Appl. Entomol. Zool. 41, 145-150. doi: 10.1303/aez.2006.145

Keasar, T., Ney-Nifle, M., Mangel, M., and Swezey, S. (2001). Early oviposition experience affects patch residence time in a foraging parasitoid. Entomol. Exp. Appl. 98, 123-132. doi: 10.1046/j.1570-7458.2001.00766.x

Kennett, C. E., Flaherty, D. L., and Hoffmann, R. W. (1979). Effect of windborne pollens on the population dynamics of Amblyseius hibisci [Acarina: Phytoseiidae]. Entomophaga 24, 83-98. doi: 10.1007/BF02377513

Khanamani, M., Fathipour, Y., Talebi, A. A., and Mehrabadi, M. (2017). Quantitative analysis of long-term mass rearing of Neoseiulus californicus (Acari: Phytoseiidae) on almond pollen. J. Econ. Entomol. 110, 1442-1450. doi: $10.1093 /$ jee/tox116

Khodayari, S., Fathipour, Y., and Kamali, K. (2013). Life history parameters of Phytoseius plumifer (Acari: Phytoseiidae) fed on corn pollen. Acarologia 53, 185-189. doi: 10.1051/acarologia/20132087

Kidane, D., Yang, N. W., and Wan, F. H. (2018). Evaluation of a banker plant system for biological control of Bemisia tabaci (Hemiptera: Aleyrodidae) on tomato, using two aphelinid parasitoids under field-cage conditions. Biocontrol. Sci. Technol. 28, 1054-1073. doi: 10.1080/09583157.2018.1510899

Kim, Y., and Kim, J. (2004). "Biological control of Aphis gossypii using barley banker plants in greenhouse grown oriental melon," in California Conference on Biological Control IV (Berkeley, CA: Center for Biological Control, College of Natural Resources, University of California), 124-126.

Kim, Y. H. (2003). Biological control of aphids on cucumber in plastic green houses using banker plants. Korean J. Appl. Entomol. 42, 81-84.
Kiman, Z. B., and Yeargan, K. V. (1985). Development and reproduction of the predator Orius insidiosus (Hemiptera: Anthocoridae) reared on diets of selected plant material and arthropod prey. Ann. Entomol. Soc. Am. 78, 464-467. doi: 10.1093/aesa/78.4.464

Kirk, W. D. (1987). How much pollen can thrips destroy? Ecol. Entomol. 12, 31-40. doi: 10.1111/j.1365-2311.1987.tb00982.x

Koch, R. L. (2003). The multicolored Asian lady beetle, Harmonia axyridis: a review of its biology, uses in biological control, and non-target impacts. J. Insect Sci. 3, 1-16. doi: 10.1673/031.003.3201

Koike, A., Nemoto, H., and Amano, H. (2000). New trap for survey of species structure and seasonal dynamics of phytoseiid mites on Japanese pear trees (Acari: Phytoseiidae). Jpn. J. Appl. Entomol. Zool. 44, 35-40. doi: 10.1303/jjaez.2000.35

Kolokytha, P. D., Fantinou, A. A., and Papadoulis, G. T. (2011). Effect of several different pollens on the bio-ecological parameters of the predatory mite Typhlodromus athenas Swirski and Ragusa (Acari: Phytoseiidae). Environ. Entomol. 40, 597-604. doi: 10.1603/EN10276

Koptur, S. (1992a). "Extrafloral nectary-mediated interactions between insects and plants," in Insect-Plant Interactions, ed E. A. Bernays (Boca Raton, FL: CRC Press), 81-129.

Koptur, S. (1992b). Interactions between insects and plants mediated by extrafloral nectaries. CRC Series Insect/Plant Interact. 4, 85-132.

Kost, C., and Heil, M. (2005). Increased availability of extrafloral nectar reduces herbivory in Lima bean plants (Phaseolus lunatus, Fabaceae). Basic Appl. Ecol. 6, 237-248. doi: 10.1016/j.baae.2004.11.002

Kostiainen, T., and Hoy, M. A. (1994). Egg-harvesting allows large scale rearing of Amblyseius finlandicus (Acari: Phytoseiidae) in the laboratory. Exp. Appl. Acarol. 18, 155-165. doi: 10.1007/BF02353683

Kreiter, S., Tixier, M. S., and Bourgeois, T. (2003). Do generalist phytoseiid mites (Gamasida: Phytoseiidae) have interactions with their host plants? Int. J. Trop. Insect Sci. 23, 35-50. doi: 10.1017/S17427584000 12236

Kumar, V., Wekesa, V. W., Avery, P. B., Powell, C. A., McKenzie, C. L., and Osborne, L. S. (2014). Effect of pollens of various ornamental pepper cultivars on the development and reproduction of Amblyseius swirskii (Acari: Phytoseiidae). Fla. Entomol. 97, 367-373. doi: 10.1653/024.09 7.0205

Kumar, V., Xiao, Y., McKenzie, C. L., and Osborne, L. S. (2015). Early establishment of the phytoseiid mite Amblyseius swirskii (Acari: Phytoseiidae) on pepper seedlings in a Predator-in-first approach. Exp. Appl. Acarol. 65, 465-481. doi: 10.1007/s10493-015-9895-2

Kuo-Sell, H. L. (1987). "Some bionomics of the predacious aphid midge, Aphidoletes aphidimyza (Rond.) (Diptera: Cecidomyiidae), and the possibility of using the rose grain aphid, Metopolophium dirhodum (Wlk.), as an alternative prey in an open rearing unit in greenhouses," in Meeting of the EC Experts' Group (Heraklion: Balkema), 24-26.

Kuo-Sell, H. L. (1989). Cereal aphids as a basis for the biological control of the peach aphid, Myzus persicae (Sulz.), with Aphidoletes aphidimyza (Rond.) (Dipt., Cecidomyiidae) in greenhouses. J. Appl. Entomol. 107, 58-64. doi: 10.1111/j.1439-0418.1989.tb00228.x

Kütük, H. (2018). Performance of the predator Amblyseius swirskii (AthiasHenriot) (Acari: Phytoseiidae) on plastic greenhouse pepper sprayed vs unsprayed pine pollen. Derim 35, 135-140. doi: 10.16882/derim.2018.396951

Kütük, H., and Yigit, A. (2011). Pre-establishment of Amblyseius swirskii (AthiasHenriot) (Acari: Phytoseiidae) using Pinus brutia (Ten.) (Pinales: Pinaceae) pollen for thrips (Thysanoptera: Thripidae) control in greenhouse peppers. Int. J. Acarol. 37, 95-101. doi: 10.1080/01647954.2010.540081

Labbé, R. M., Gagnier, D., Kostic, A., and Shipp, L. (2018). The function of supplemental foods for improved crop establishment of generalist predators Orius insidiosus and Dicyphus hesperus. Sci. Rep. 8:17790. doi: 10.1038/s41598-018-36100-0

Lambert, L., Chouffot, T., Tureotte, G., Lemieux, M., and Moreau, J. (2005). Biological control of greenhouse whitefly (Trialeurodes vaporariorum) on interplanted tomato crops with and without supplemental lighting using Dicyphus hesperus. IOBC/WPRS Bull. 28, 175-178.

Lamparter, B. (1992). Introduction of beneficial organisms in greenhouse cucumbers-problem cotton aphid Aphis gossypii-a report from Insel Reichenau. Gesunde Pflanzen 44, 229-232. 
Laska, P., and Zelenkova, I. (1988). Comparison of Aleyrodes proletella in borecole and Trialeurodes vaporariorum (Homoptera, Aleyrodidae) in common bean and gerberas as hosts of Encarsia formosa (Hymenoptera, Aphelinidae). Acta Entomol. Bohemoslov. 85, 473-474.

Laurenz, S., and Meyhöfer, R. (2017). Banker plants promote functional biodiversity in cabbage. Landscape management for functional biodiversity. IOBC/WPRS Bull. 122, 16-20.

Lawson-Balagbo, L. M., Gondim, M. G. C., De Moraes, G. J., Hanna, R., and Schausberger, P. (2007). Life history of the predatory mites Neoseiulus paspalivorus and Proctolaelaps bickleyi, candidates for biological control of Aceria guerreronis. Exp. Appl. Acarol. 43, 49-61. doi: $10.1007 /$ s10493-007-9101-2

Lee, M. H., and Zhang, Z. Q. (2016). Habitat structure and its influence on populations of Amblydromalus limonicus (Acari: Phytoseiidae). Syst. Appl. Acarol. 21, 1361-11378. doi: 10.11158/saa.21.10.7

Lee, M. H., and Zhang, Z. Q. (2018). Assessing the augmentation of Amblydromalus limonicus with the supplementation of pollen, thread, and substrates to combat greenhouse whitefly populations. Sci. Rep. 8:12189. doi: 10.1038/s41598-018-30018-3

Legarrea, S., Dong, L., Glas, J., van Houten, Y., and Kant, M. R. (2020). Distorted tomato trichomes facilitate biological control of the tomato russet mite using predatory mites. IOBC/WPRS Bull. 149, 81-82.

Leman, A., and Messelink, G. J. (2015). Supplemental food that supports both predator and pest: a risk for biological control? Exp. Appl. Acarol. 65, 511-524. doi: 10.1007/s10493-014-9859-y

Lenfant, C., Ridray, G., and Schoen, L. (2000). Biopropagation of Macrolophus caliginosus Wagner for a quicker establishment in Southern tomato greenhouses. OILB/SROP Bull. 23, 247-251.

Lester, P. J., Thistlewood, H. M. A., and Harmsen, R. (2000). Some effects of pre-release host-plant on the biological control of Panonychus ulmi by the predatory mite Amblyseius fallacis. Exp. Appl. Acarol. 24, 19-33. doi: 10.1023/A:1006345119387

Letourneau, D. K. (1983). The Effects of Vegetational Disersity on Herbivorous Insects and Associated Natural Enemies: Examples From Tropical and Temperate Agroecosystems. Berkeley, CA: University of California.

Letourneau, D. K. (1990). "Two examples of natural enemy augmentation: a consequence of crop diversification," in Agroecology, ed S. R. Gliessman (New York, NY: Springer Inc.), 11-29.

Li, L., Tsao, R., Yang, R., Kramer, J. K., and Hernandez, M. (2007). Fatty acid profiles, tocopherol contents, and antioxidant activities of heartnut (Juglans ailanthifolia Var. cordiformis) and persian walnut (Juglans regia L.). J. Agric. Food Chem. 55, 1164-1169. doi: 10.1021/jf062322d

Liu, J. F., and Zhang, Z. Q. (2017). Development, survival and reproduction of a New Zealand strain of Amblydromalus limonicus (Acari: Phytoseiidae) on Typha orientalis pollen, Ephestia kuehniella eggs, and an artificial diet. Int. J. Acarol. 43, 153-159. doi: 10.1080/01647954.2016.1273972

Liu, J. F., Zhang, Z. Q., Beggs, J. R., and Zou, X. (2019). Provisioning predatory mites with entomopathogenic fungi or pollen improves biological control of a greenhouse psyllid pest. Pest Manag. Sci. 75, 3200-3209. doi: 10.1002/ps.5438

Loughner, R., Goldman, K., Loeb, G., and Nyrop, J. (2008). Influence of leaf trichomes on predatory mite (Typhlodromus pyri) abundance in grape varieties. Exp. Appl. Acarol. 45, 111-122. doi: 10.1007/s10493-008-9183-5

Loughner, R., Nyrop, J., Wentworth, K., and Sanderson, J. (2011). Towards enhancing biocontrol of thrips: effects of supplemental pollen and fibers on foliar abundance of Amblyseius swirskii. IOBC/WPRS Bull. 68, 105-109.

Loughner, R., Wentworth, K., Loeb, G., and Nyrop, J. (2010). Influence of leaf trichomes on predatory mite density and distribution in plant assemblages and implications for biological control. Biol. Control 54, 255-262. doi: 10.1016/j.biocontrol.2010.05.017

Lucas, E., and Alomar, O. (2001). Macrolophus caliginosus (Wagner) as an intraguild prey for the zoophytophagous Dicyphus tamaninii Wagner (Heteroptera: Miridae). Biol. Control 20, 147-152. doi: 10.1006/bcon. 2000.0890

Lucas, É., and Alomar, O. (2002). Impact of the presence of Dicyphus tamaninii Wagner (Heteroptera: Miridae) on whitefly (Homoptera: Aleyrodidae) predation by Macrolophus caliginosus (Wagner) (Heteroptera: Miridae). Biol. Control 25, 123-128. doi: 10.1016/S1049-9644(02)00054-3
Lucas, É., and Brodeur, J. (1999). Oviposition site selection by the predatory midge Aphidoletes aphidimyza (Diptera: Cecidomyiidae). Environ. Entomol. 28, 622-627. doi: 10.1093/ee/28.4.622

Lundgren, J. G. (2009). Relationships of Natural Enemies and non Prey Foods. Progress in Biological Control 7. New York, NY: Springer Science and Business Media.

Lundgren, J. G., Fergen, J. K., and Riedell, W. E. (2008). The influence of plant anatomy on oviposition and reproductive success of the omnivorous bug Orius insidiosus. Anim. Behav. 75, 1495-1502. doi: 10.1016/j.anbehav.2007.09.029

Lundgren, J. G., Huber, A., and Wiedenmann, R. N. (2005). Quantification of consumption of corn pollen by the predator Coleomegilla maculata (Coleoptera: Coccinellidae) during anthesis in an Illinois cornfield. Agr. For. Entomol. 7, 53-60. doi: 10.1111/j.1461-9555.2005.00246.x

Lundgren, J. G., and Wiedenmann, R. N. (2004). Nutritional suitability of corn pollen for the predator Coleomegilla maculata (Coleoptera: Coccinellidae). J. Insect Physiol. 50, 567-575. doi: 10.1016/j.jinsphys.2004.04.003

Lundstrom, A. N. (1887). Pflanzenbiologische Studien. II. Die Anpassungen der Pflanzen an Thiere. Nova Acta Regiae Soc. Sci. Upsal. 3, 1-87.

Lykouressis, D., Giatropoulos, A., Perdikis, D., and Favas, C. (2008). Assessing the suitability of noncultivated plants and associated insect prey as food sources for the omnivorous predator Macrolophus pygmaeus (Hemiptera: Miridae). Biol. Control 44, 142-148. doi: 10.1016/j.biocontrol.2007.11.003

Lyon, J. P. (1973). Utilisation des entomophages pour la limitation des populations en serre. IOBC/WPRS Bull. 4, 47-49.

Madadi, H. (2018). Enhancing predator efficiency, the recent advances. Arch Phytopathol. Plant Prot. 51, 754-778. doi: 10.1080/03235408.2018.1464262

Maes, S., Antoons, T., Grégoire, J. C., and De Clercq, P. (2014). A semi-artificial rearing system for the specialist predatory ladybird Cryptolaemus montrouzieri. Biocontrol 59, 557-564. doi: 10.1007/s10526-014-9585-8

Maisonneuve, J. C. (2002). Biological control in France in greenhouse vegetables and ornamentals. IOBC/WPRS Bull. 25, 151-154.

Mandour, N. S., Ren, S. X., and Qiu, B. L. (2007). Effect of Bemisia tabaci honeydew and its carbohydrates on search time and parasitization of Encarsia bimaculata. J. Appl. Entomol. 131, 645-651. doi: 10.1111/j.1439-0418.2007. 01165.x

Maoz, Y., Gal, S., Argov, Y., Domeratzky, S., Melamed, E., Gan-Mor, S., et al. (2014). Efficacy of indigenous predatory mites (Acari: Phytoseiidae) against the citrus rust mite Phyllocoptruta oleivora (Acari: Eriophyidae): augmentation and conservation biological control in Israeli citrus orchards. Exp. Appl. Acarol. 63, 295-312. doi: 10.1007/s10493-014-9786-y

Markkula, M., and Tiittanen, K. (1976). Pest in first and natural infestation methods in the control of Tetranychus urticae koch with Phytoseiulus persimilis athias-henriot on glasshouse cucumbers. Ann. Agr. Fenn. 15, 81-85.

Martin, C., Schoen, L., and Arrufat, A. (1998). "Systèmes de plantes relais en cultures maraîchères, exemple d'application au contrôle intégrée d'Aphis gossypii Glover en Languedoc Roussillon.", in First transnational workshop on biological, integrated and rational control: status and perspectives with regard to regional and European experiences, Lille, France, (Loosen-Gohelle: Service Régional de la Protection des Végétaux), 31-32.

Massaro, M., Martin, J. P. I., and de Moraes, G. J. (2016). Factitious food for mass production of predaceous phytoseiid mites (Acari: Phytoseiidae) commonly found in Brazil. Exp. Appl. Acarol. 70, 411-420. doi: 10.1007/s10493-016-0087-5

Matsuo, T., Mochizuki, M., Yara, K., Mitsunaga, T., and Mochizuki, A. (2003). Suitability of pollen as an alternative diet for Amblyseius cucumeris (Oudeman), Jpn. J. Appl. Entomol. Zool. 47, 153-158. doi: 10.1303/jjaez.2003.153

Matsuo, T. (2003). Control of cotton aphid on strawberry by banker plants. Plant Prot. 57, 369-372.

Matteoni, J. A. (2003). "Economics of banker plant systems in Canadian greenhouse crops," in Proceedings of the International Symposium on Biological Control of Arthropods, Honolulu, HI, ed R. G. VanDriesche (Washington, DC: USDA Forest Service, Forest Health Technology Enterprise Team), 154-157.

McClure, T., and Frank, S. D. (2015). Grain diversity effects on banker plant growth and parasitism by Aphidius colemani. Insects 6, 772-791. doi: 10.3390 /insects6030772

McClure, T. J. (2014). Factors affecting aphid with banker plant systems [Master thesis]. North Carolina State University, Raleigh, NC,United States. 
McMurtry, J. A., and Croft, B. A. (1997). Life-styles of phytoseiid mites and their roles in biological control. Annu. Rev. Entomol. 42, 291-321. doi: 10.1146/annurev.ento.42.1.291

McMurtry, J. A., and Johnson, H. G. (1965). Some factors influencing the abundance of the predaceous mite Amblyseius hibisci in southern California (Acarina: Phytoseiidae). Ann. Entomol. Soc. Am. 58, 49-56. doi: 10.1093/aesa/58.1.49

McMurtry, J. A., and Scriven, G. T. (1964). Studies on the feeding, reproduction, and development of Amblyseius hibisci (Acarina: Phytoseiidae) on various food substances. Ann. Entomol. Soc. Am. 57, 649-655. doi: 10.1093/aesa/57.5.649

McMurtry, J. A., and Scriven, G. T. (1966). Studies on predator-prey interactions between Amblyseius hibisci and Oligonychus punicae (Acarina: Phytoseiidae, Tetranychidae) under greenhouse conditions. Ann. Entomol. Soc. Am. 59, 793-800. doi: 10.1093/aesa/59.4.793

Messelink, G., van Steenpaal, S., and van Wensveen, W. (2005). Typhlodromips swirskii (Athias-Henriot) (Acari: Phytoseiidae): a new predator for thrips control in greenhouse cucumber. IOBC/WPRS Bull. 28, 183-186.

Messelink, G. J., Bennison, J., Alomar, O., Ingegno, B. L., Tavella, L., Shipp, L., et al. (2014). Approaches to conserving natural enemy populations in greenhouse crops: current methods and future prospects. Biocontrol 59, 377-393. doi: 10.1007/s10526-014-9 579-6

Messelink, G. J., Bloemhard, C. M. J., Hoogerbrugge, H., Van Schelt, J., Ingegno, B. L., and Tavella, L. (2015). Evaluation of mirid predatory bugs and release strategy for aphid control in sweet pepper. J. Appl. Entomol. 139, 333-341. doi: $10.1111 /$ jen. 12170

Messelink, G. J., Leman, A., Ghasemzadeh, S., Bloemhard, C., van Holstein, R., Vijverberg, R., et al. (2016). Geïntegreerde Bestrijding van Plagen in de Sierteelt Onder Glas (No. 172). Report Wageningen UR Glastuinbouw GTB-1420.

Messelink, G. J., Ramakers, P. M. J., Cortez, J. A., and Janssen, A. (2009). "How to enhance pest control by generalist predatory mites in greenhouse crops,". in Proceedings of the Third International Symposium on Biological Control of Arthropods (Christchurch), 8-13.

Messelink, G. J., and Van Holstein-Saj, R. (2011). Generalist predator Stratiolaelaps scimitus hampers establishment of the bulb scale mite predator Neoseiulus barkeri in Hippeastrum. Proc. Neth. Entomol. Soc. Meet. 22, 67-74.

Messelink, G. J., and Van Holstein-Saj, R. (2007). Biological control of the bulb scale mite Steneotarsonemus laticeps (Acari: Tarsonemidae) with Neoseiulus barkeri (Acari: Phytoseiidae) in amaryllis. IOBC/WPRS Bull. 30:81.

Messelink, G. J., van Maanen, R., van Steenpaal, S. E., and Janssen, A. (2008). Biological control of thrips and whiteflies by a shared predator: two pests are better than one. Biol. Control 44, 372-379. doi: 10.1016/j.biocontrol.2007.10.017

Michaud, J. P., and Grant, A. K. (2005). Suitability of pollen sources for the development and reproduction of Coleomegilla maculata (Coleoptera: Coccinellidae) under simulated drought conditions. Biol. Control 32, 363-370. doi: 10.1016/j.biocontrol.2004. 11.001

Midthassel, A., Leather, S. R., and Baxter, I. H. (2013). Life table parameters and capture success ratio studies of Typhlodromips swirskii (Acari: Phytoseiidae) to the factitious prey Suidasia medanensis (Acari: Suidasidae). Exp. Appl. Acarol. 61, 69-78. doi: 10.1007/s10493-013-9682-x

Miller, J. C., and Gerth, W. J. (1994). Temperature-dependent development of Aphidius matricariae (Hymenoptera: Aphidiidae), as a parasitoid of the Russian wheat aphid. Environ. Entomol. 23, 1304-1307. doi: 10.1093/ee/23.5.1304

Miller, T. L. P. (2018). Evaluation of the Aphidius colemani-Rhopalosiphum padi Banker Plant System in Greenhouse Biological Control. PhD diss., Oklahoma State University, Stillwater, Oklahoma, USA, 120p.

Miller, T. L. P., Rebek, E. J., and Schnelle, M. A. (2017). Banker Plants for Control of Greenhouse Pests. Oklahoma Coperative Extension Services, Oklahoma State University EP-7334, 1-7.

Moerkens, R., Berckmoes, E., Van Damme, V., Wittemans, L., Tirry, L., Casteels, H., et al. (2017). Inoculative release strategies of Macrolophus pygmaeus Rambur (Hemiptera: Miridae) in tomato crops: population dynamics and dispersal. J. Plant Dis. Prot. 124, 295-303. doi: 10.1007/s41348-017-0077-9

Mollá, O., Biondi, A., Alonso-Valiente, M., and Urbaneja, A. (2014). A comparative life history study of two mirid bugs preying on Tuta absoluta and Ephestia kuehniella eggs on tomato crops: implications for biological control. Biocontrol 59, 175-183. doi: 10.1007/s10526-013-9553-8

Momen, F., Abdel-Khalek, A., and El-Sawi, S. (2009). Life tables of the predatory mite Typhlodromus negevi feeding on prey insect species and pollen diet (Acari: Phytoseiidae). Acta Phytopathol. Hun. 44, 353-361. doi: 10.1556/APhyt.44.2009.2.12

Momen, F. M. (2004). Suitability of the pollen grains, Ricinus communis and Helianthus annuus as food for six species of phytoseiid mites (Acari: Phytoseiidae). Acta Phytopathol. Hun. 39, 415-422. doi: 10.1556/APhyt.39.2004.4.10

Momen, F. M., and El-Laithy, A. Y. (2007). Suitability of the flour moth Ephestia kuehniella (Lepidoptera: Pyralidae) for three predatory phytoseiid mites (Acari: Phytoseiidae) in Egypt. Int. J. Trop. Insect Sci. 27, 102-107. doi: $10.1017 /$ S1742758407777160

Momen, F. M., and El-Saway, S. A. (1993). Biology and feeding behavior of the predatory mite, Amblyseius swirskii (Acari, Phytoseiidae). Acarologia 34, 199-204.

Monks, A., O'Connell, D. M., Lee, W. G., Bannister, J. M., and Dickinson, K. J. (2007). Benefits associated with the domatia mediated tritrophic mutualism in the shrub Coprosma lucida. Oikos 116, 873-881. doi: 10.1111/j.0030-1299.2007.15654.x

Montserrat, M., Guzmán, C., Sahún, R. M., Belda, J. E., and Hormaza, J. I. (2013). Pollen supply promotes, but high temperatures demote, predatory mite abundance in avocado orchards. Agric. Ecosyst. Environ. 164, 155-161. doi: 10.1016/j.agee.2012.09.014

Mullen, G. R., and O'Connor, B. M. (2019). Mites (Acari). in Medical and veterinary entomology. Academic Press. 533-602. doi: 10.1016/B978-0-12-814043-7.00026-1

Muñoz-Cárdenas, K., Ersin, F., Pijnakker, J., van Houten, Y., Hoogerbrugge, H., Leman, A., et al. (2017). Supplying high-quality alternative prey in the litter increases control of an above-ground plant pest by a generalist predator. Biol. Control 105, 19-26. doi: 10.1016/j.biocontrol.2016.11.004

Nagai, K., Hirose, Y., Takagi, M., Nakashima, Y., and Hiramatsu, T. (1998). Selection of alternative prey for rearing Orius tantillus (Motshulsky). Japan J. Appl. Entomol. Zool. 42, 85-87. doi: 10.1303/jjaez.42.85

Nagasaka, K., and Oya, S. (2003). A practical application of a banker plant system to aphid control in greenhouses. Plant Prot. 57, 505-509.

Nagasaka, K., Takahashi, N., and Okabayashi, T. (2010). Impact of secondary parasitism on Aphidius colemani in the banker plant system on aphid control in commercial greenhouses in Kochi, Jpn. J. Appl. Entomol. Zool. 45, 541-550. doi: 10.1303/aez.2010.541

Nagasaka, K., Takahashi, N., Okabayashi, T., Abe, J., and Ohya, S. (2011). Development of a practical banker plant system for aphid control in commercial greenhouse crops in Japan. Bull. Nat. Agric. Res. Center 15, 1-39.

Nakaishi, K., Fukui, Y., and Arakawa, R. (2011). Reproduction of Nesidiocoris tenuis (Reuter) on sesame. Jpn J. Appl. Entomol. Zool. 55, 199-205. doi: 10.1303/jjaez.2011.199

Naranjo, S. E., and Gibson, R. L. (1996). "Phytophagy in predaceous Heteroptera: effects on life history and population dynamics," in Zoophytophagous Heteroptera: Implications for Life History and Integrated Pest Management, eds O. Alomar and R. N. Wiedenmann (Lanham, MD: Entomological Society of America), 57-93.

Naselli, M., Urbaneja, A., Siscaro, G., Jaques, J. A., Zappal,à, L., Flors, V., et al. (2016). Stage-related defense response induction in tomato plants by Nesidiocoris tenuis. Int. J. Mol. Sci. 17:1210. doi: 10.3390/ijms17081210

Navarro-Campos, C., Pekas, A., Moraza, M. L., Aguilar, A., and Garcia-Mar,í, F. (2012). Soil-dwelling predatory mites in citrus: their potential as natural enemies of thrips with special reference to Pezothrips kellyanus (Thysanoptera: Thripidae). Biol. Control 63, 201-209. doi: 10.1016/j.biocontrol.2012. 07.007

Navarro-Campos, C., Wäckers, F. L., and Pekas, A. (2016). Impact of factitious foods and prey on the oviposition of the predatory mites Gaeolaelaps aculeifer and Stratiolaelaps scimitus (Acari: Laelapidae). Exp. Appl. Acarol. 70, 69-78. doi: 10.1007/s10493-016-0061-2

Neves Esteca, F. D. C., Trandem, N., Klingen, I., Cruz Santos, J., Delalibera Júnior, I., and de Moraes, G. J. (2020). Cereal straw mulching in strawberry - a facilitator of plant visits by edaphic predatory mites at night? Diversity 12:242. doi: $10.3390 / \mathrm{d} 12060242$ 
Nguyen, D. T., Vangansbeke, D., and De Clercq, P. (2014a). Artificial and factitious foods support the development and reproduction of the predatory mite Amblyseius swirskii. Exp. Appl. Acarol. 62, 181-194. doi: 10.1007/s10493-013-9749-8

Nguyen, D. T., Vangansbeke, D., and De Clercq, P. (2014b). Solid artificial diets for the phytoseiid predator Amblyseius swirskii. BioControl 59, 719-727. doi: 10.1007/s10526-014-9607-6

Nguyen, D. T., Vangansbeke, D., and De Clercq, P. (2015). Performance of four species of phytoseiid mites on artificial and natural diets. Biol. Control 80, 56-62. doi: 10.1016/j.biocontrol.2014.09.016

Nguyen, D. T., Vangansbeke, D., Lü, X., and De Clercq, P. (2013). Development and reproduction of the predatory mite Amblyseius swirskii on artificial diets. Biocontrol 58, 369-377. doi: 10.1007/s10526-012-9502-y

Nguyen-Dang, L., Vankosky, M., and VanLaerhoven, S. (2016). The effects of alternative host plant species and plant quality on Dicyphus hesperus populations. Biol. Control 100, 94-100. doi: 10.1016/j.biocontrol.2016.05.016

Nishimori, T., Miura, K., and Seko, T. (2016). Rearing Orius strigicollis (Hemiptera: Anthocoridae) on an alternative diet of brine shrimp, Artemia salina (Anostraca: Artemiidae). Appl. Entomol. Zool. 51, 321-325. doi: $10.1007 / \mathrm{s} 13355-015-0388-\mathrm{x}$

Nomikou, M. (2003) Combating whiteflies: predatory mites as a novel weapon [Ph.D. thesis], University of Amsterdam, IBED, Amsterdam, Netherlands.

Nomikou, M., Janssen, A., Schraag, R., and Sabelis, M. W. (2001). Phytoseiid predators as potential biological control agents for Bemisia tabaci. Exp. Appl. Acarol. 25, 271-291. doi: 10.1023/A:1017976725685

Nomikou, M., Janssen, A., Schraag, R., and Sabelis, M. W. (2002). Phytoseiid predators suppress populations of Bemisia tabaci on cucumber plants with alternative food. Exp. Appl. Acarol. 27, 57-68. doi: 10.1023/A:1021559421344

Nomikou, M., Sabelis, M. W., and Janssen, A. (2010). Pollen subsidies promote whitefly control through the numerical response of predatory mites. Biocontrol 55, 253-260. doi: 10.1007/s10526-009-9233-x

Norton, A. P., English-Loeb, G., and Belden, E. (2001). Host plant manipulation of natural enemies: leaf domatia protect beneficial mites from insect predators. Oecologia 126, 535-542. doi: 10.1007/s004420000556

Norton, A. P., English-Loeb, G., Gadoury, D., and Seem, R. C. (2000). Mycophagous mites and foliar pathogens: leaf domatia mediate tritrophic interactions in grapes. Ecology 81, 490-499. doi: 10.1890/0012-9658(2000)0810490:MMAFPL2.0.CO;2

Ode, P. J. (2006). Plant chemistry and natural enemy fitness: effects on herbivore and natural enemy interactions. Annu. Rev. Entomol. 51, 163-185. doi: 10.1146/annurev.ento.51.110104.151110

Ode, P. J., Hopper, K. R., and Coll, M. (2005). Oviposition vs. offspring fitness in Aphidius colemani parasitizing different aphid species. Entomol. Exp. Appl. 115, 303-310. doi: 10.1111/j.1570-7458.2005.00261.x

O'Dowd, D. J., and Willson, M. F. (1991). Associations between mites and leaf domatia. Trends Ecol. Evol. 6, 179-182. doi: 10.1016/0169-5347(91)90209-G

O'Dowd, D. J., and Willson, M. F. (1997). Leaf domatia and the distribution and abundance of foliar mites in broadleaf deciduous forest in Wisconsin. Am. Midl. Nat. 137, 337-348. doi: 10.2307/2426853

Ohta, I., and Honda, K. I. (2010). Use of Sitobion akebiae (Hemiptera: Aphididae) as an alternative host aphid for a banker-plant system using an indigenous parasitoid, Aphidius gifuensis (Hymenoptera: Braconidae). Appl. Entomol. Zool. 45, 233-238. doi: 10.1303/aez.2010.233

Oida, H., and Kadono, F. (2012). Development of Geocoris varius and G. proteus (Hemiptera: Geocoridae) provided with Ephestia kuehniella (Lepidoptera: Pyralidae) eggs. Appl. Entomol. Zool. 47, 365-372. doi: 10.1007/s13355-012-0127-5

Onzo, A., Hanna, R., Negloh, K., Toko, M., and Sabelis, M. W. (2005). Biological control of cassava green mite with exotic and indigenous phytoseiid predatorseffects of intraguild predation and supplementary food. Biol. Control 33, 143-152. doi: 10.1016/j.biocontrol.2005.02.006

Onzo, A., Houedokoho, A. F., Hanna, R., and Liu, T. X. (2012). Potential of the predatory mite, Amblyseius swirskii to suppress the broad mite, Polyphagotarsonemus latus on the gboma eggplant, Solanum macrocarpon. J. Insect Sci. 12:7. doi: 10.1673/031.012.0701

Osakabe, M., Inoue, K., and Ashihara, W. (1986). Feeding, reproduction and development of Amblyseius sojaensis Ehara (Acarina: Phytoseiidae) on two species of spider mites and on tea pollen. Appl. Entomol. Zool. 21, 322-327. doi: 10.1303/aez.21.322

Osborne, L. S., and Barrett, J. E. (2005). You can bank on it. Ornamental Outlook, 26-27.

Osborne, L. S., Landa, Z., Taylor, D. J., and Tyson, R. V. (2005). Using banker plants to control insects in greenhouse vegetables. In Proc. Fla. State Hort. Soc. $118,127-128$.

Ouyang, Y., Grafton-Cardwell, E. E., and Bugg, R. L. (1992). Effects of various pollens on development, survivorship, and reproduction of Euseius tularensis (Acari: Phytoseiidae). Environ. Entomol. 21, 1371-1376. doi: 10.1093/ee/21.6.1371

Oveja, M. F., Riudavets, J., Arn,ó, J., and Gabarra, R. (2016). Does a supplemental food improve the effectiveness of predatory bugs on cucumber? Biocontrol 61, 47-56. doi: 10.1007/s10526-015-9690-3

Oveja, M. F., Arnó, J., and Gabarra, R. (2012). Effect of supplemental food on the fitness of four omnivorous predator species. IOBC/WPRS Bull. 80, 97-101.

Overmeer, W. P. J. (1981). Notes on breeding phytoseiid mites from orchards (Acarina: Phytoseiidae) in the laboratory. Med. Fac. Landbouww. Univ. Gent. 46, 503-509.

Overmeer, W. P. J. (1985). "Rearing and handling," in Spider Mites: their Biology, Natural Enemies and Control 1, eds W. Helle and M. W. Sabelis (Amsterdam: Elsevier Science Publishers B.V.), 161-170.

Owashi, Y., Hayashi, M., Abe, J., and Miura, K. (2020). Effects of an alternative diet of Artemia cysts on the development and reproduction of Nesidiocoris tenuis (Hemiptera: Miridae). Appl. Entomol. Zool. 55, 121-127. doi: 10.1007/s13355-019-00660-y

Palevsky, E. (2016). Pollen provisioning for the promotion of biological control by omnivorous phytoseiids in organic greenhouses. Acta Horticult. 1164, 383-390. doi: 10.17660/ActaHortic.2017.1164.49

Papadopoulos, G. D., and Papadoulis, G. T. (2008). Effect of seven different pollens on bio-ecological parameters of the predatory mite Typhlodromus foenilis (Acari: Phytoseiidae). Environ. Entomol. 37, 340-347. doi: 10.1603/0046-225X(2008)37340:EOSDPO2.0.CO;2

Pappas, M. L., Broekgaarden, C., Broufas, G. D., Kant, M. R., Messelink, G. J., Steppuhn, A., et al. (2017). Induced plant defences in biological control of arthropod pests: a double-edged sword. Pest Manag. Sci. 73, 1780-1788. doi: $10.1002 /$ ps.4587

Pappas, M. L., Steppuhn, A., and Broufas, G. D. (2016). The role of phytophagy by predators in shaping plant interactions with their pests. Commun. Integr. Biol. 9:e0127251. doi: 10.1080/19420889.2016.1145320

Pappas, M. L., Steppuhn, A., Geuss, D., Topalidou, N., Zografou, A., Sabelis, M. W., et al. (2015). Beyond predation: the zoophytophagous predator Macrolophus pygmaeus induces tomato resistance against spider mites. PLoS ONE 10:e0127251. doi: 10.1371/journal.pone.0127251

Paré, P. W., and Tumlinson, J. H. (1999). Plant volatiles as a defense against insect herbivores. Plant Physiol. 121, 325-332. doi: 10.1104/pp.121.2.325

Park, H. H., Shipp, L., and Buitenhuis, R. (2010). Predation, development, and oviposition by the predatory mite Amblyseius swirkii (Acari: Phytoseiidae) on tomato russet mite (Acari: Eriophyidae). J. Econ. Entomol. 103, 563-569. doi: 10.1603/EC09161

Park, H. H., Shipp, L., Buitenhuis, R., and Ahn, J. J. (2011). Life history parameters of a commercially available Amblyseius swirskii (Acari: Phytoseiidae) fed on cattail (Typha latifolia) pollen and tomato russet mite (Aculops lycopersici). J. Asia Pac. Entomol. 14, 497-501. doi: 10.1016/j.aspen.2011.07.010

Parker, L., and Popenoe, J. (2008). Using banker plants as a biocontrol system for spidermites. Proc. Fla. State Hort. Soc. 121, 385-386.

Parolin, P., Bresch, C., Desneux, N., Brun, R., Bout, A., Boll, R., et al. (2012a). Secondary plants used in biological control: a review. Int. J. Pest. Manag. 58, 91-100. doi: 10.1080/09670874.2012.659229

Parolin, P., Bresch, C., Poncet, C., and Desneux, N. (2012b). Functional characteristics of secondary plants for increased pest management. Int. J. Pest. Manag. 58, 368-376. doi: 10.1080/09670874.2012.734869

Parolin, P., Bresch, C., Ruiz, G., Desneux, N., and Poncet, C. (2013). Testing banker plants for biological control of mites on roses. Phytoparasitica 41, 249-262. doi: 10.1007/s12600-012-0285-6

Parr, B. W. J., Gould, H. J., Jessop, N. H., and Ludlam, F. A. B. (1976). Progress towards a biological control programme for glasshouse whitefly 
(Trialeurodes vaporariorum) on tomatoes. Ann. Appl. Biol. 83, 349-363. doi: 10.1111/j.1744-7348.1976.tb01707.x

Parr, W. J., and Stacey, D. L. (1975). 'Banker'- plant system of whitefly parasite release on tomatoes. Rep. Glasshouse Crops Res. Inst. 26, 63-66. doi: 10.1111/j.1365-3059.1977.tb01025.x

Pascua, M. S., Rocca, M., Greco, N., and De Clercq, P. (2020). Typha angustifolia L. pollen as an alternative food for the predatory mite Neoseiulus californicus (McGregor) (Acari: Phytoseiidae). Syst. Appl. Acarol. 25, 51-62. doi: $10.11158 /$ saa.25.1.4

Patt, J. M., Wainright, S. C., Hamilton, G. C., Whittinghill, D., Bosley, K., Dietrick, J., et al. (2003). Assimilation of carbon and nitrogen from pollen and nectar by a predaceous larva and its effects on growth and development. Ecol. Entomol. 28, 717-728. doi: 10.1111/j.1365-2311.2003.00556.x

Payton Miller, T. L., and Rebek, E. J. (2018). Banker plants for aphid biological control in greenhouses. J. Integr. Pest Manag. 9:9. doi: 10.1093/jipm/pmy002

Pease, C. G., and Zalom, F. G. (2010). Influence of non-crop plants on stink bug (Hemiptera: Pentatomidae) and natural enemy abundance in tomatoes. J. Appl. Entomol. 134, 626-636. doi: 10.1111/j.1439-0418.2009.01452.x

Pekas, A., De Craecker, I., Boonen, S., Wäckers, F. L., and Moerkens, R. (2020). One stone; two birds: concurrent pest control and pollination services provided by aphidophagous hoverflies. Biol Control 149:104328. doi: 10.1016/j.biocontrol.2020.104328

Pekas, A., and Wäckers, F. L. (2017). Multiple resource supplements synergistically enhance predatory mite populations. Oecologia 184, 479-484. doi: 10.1007/s00442-017-3877-5

Pemberton, R. W., and Turner, C. E. (1989). Occurrence of predatory and fungivorous mites in leaf domatia. Am. J. Bot. 76, 105-112. doi: 10.1002/j.1537-2197.1989.tb11290.x

Pemberton, R. W., and Vandenberg, N. J. (1993). Extrafloral nectar feeding by ladybird beetles (Coleoptera: Coccinellidae). P. Entomol. Soc. Wash. 95, 139-151.

Perdikis, D., and Arvaniti, K. (2016). Nymphal development on plant vs. leaf with and without prey for two omnivorous predators: Nesidiocoris tenuis (Reuter, 1895) (Hemiptera: Miridae) and Dicyphus errans (Wolff, 1804) (Hemiptera: Miridae). Entomol. Gen. 35, 297-306. doi: 10.1127/entomologia/2016/0219

Perdikis, D., Favas, C., Lykouressis, D., and Fantinou, A. (2007). Ecological relationships between non-cultivated plants and insect predators in agroecosystems: the case of Dittrichia viscosa (Asteraceae) and Macrolophus melanotoma (Hemiptera: Miridae). Acta Oecol. 31, 299-306. doi: 10.1016/j.actao.2006.12.005

Perdikis, D., and Lykouressis, D. (2000). Effects of various items, host plants, and temperatures on the development and survival of Macrolophus pygmaeus Rambur (Hemiptera: Miridae). Biol. Control 17, 55-60. doi: 10.1006/bcon.1999.0774

Pérez-Hedo, M., Bouagga, S., Jaques, J. A., Flors, V., and Urbaneja, A. (2015a). Tomato plant responses to feeding behavior of three zoophytophagous predators (Hemiptera: Miridae). Biol. Control 86, 46-51. doi: 10.1016/j.biocontrol.2015.04.006

Pérez-Hedo, M., Urbaneja-Bernat, P., Jaques, J. A., Flors, V., and Urbaneja, A. (2015b). Defensive plant responses induced by Nesidiocoris tenuis (Hemiptera: Miridae) on tomato plants. J. Pest Sci. 88, 543-554. doi: 10.1007/s10340-014-0640-0

Pfannenstiel, R. S., and Yeargan, K. V. (1998). Ovipositional preference and distribution of eggs in selected field and vegetable crops by Nabis roseipennis (Hemiptera: Nabidae). J. Entomol. Sci. 33, 82-89. doi: 10.18474/0749-8004-33.1.82

Pickett, C. H., Simmons, G. S., Lozano, E., and Goolsby, J. A. (2004). Augmentative biological control of whiteflies using transplants. Biocontrol 49, 665-688. doi: 10.1007/s10526-004-0270-1

Picó, F. X., and Retana, J. (2000). Temporal variation in the female components of reproductive success over the extended flowering season of a Mediterranean perennial herb. Oikos 89, 485-492. doi: 10.1034/j.1600-0706.2000. 890307.x

Pijnakker, J., Arijs, Y., de Souza, A., Cellier, M., and Wäckers, F. (2016). The use of Typha angustifolia (cattail) pollen to establish the predatory mites Amblyseius swirskii, Iphiseius degenerans, Euseius ovalis and Euseius gallicus in glasshouse crops, Integrated Control of Plant-Feeding Mites. IOBC/WPRS Bull. 120, 47-52.
Pijnakker, J., de Souza, A., and Wäckers, F. (2014). Euseius gallicus, a bodyguard for roses. IOBC/WPRS Bull. 102, 191-195.

Pijnakker, J., Vangansbeke, D., Wäckers, F., and Arijs, Y. (2017). "Building a "Standing army" of beneficials: a reality in greenhouse crops", in AFPP Conference Paper. Gème Conference sur les Moyens Alternatifs de Protection Pour une Production Intégrée, (Lille) 21, 22 et 23 mars (2017).

Pimm, S. L., and Lawton, J. H. (1978). On feeding on more than one trophic level. Nature 275, 542-544. doi: 10.1038/275542a0

Pina, T., Argolo, P. S., Urbaneja, A., and Jacas, J. A. (2012). Effect of pollen quality on the efficacy of two different life-style predatory mites against Tetranychus urticae in citrus. Biol. Control 61, 176-183. doi: 10.1016/j.biocontrol.2012.02.003

Pina, T., Argolo, P. S., Urbaneja, A., Jacas, J. A., and de Investigaciones Agrarias, V. (2015). Pollen Quality Affects Biological Control of Tetranychus urticae in Clementine Mandarines. XII Int. Citrus Cong. Int. Soc. Citricult. 1065, 1133-1136. doi: 10.17660/ActaHortic.2015.1065.143

Pineda, A., and Marcos-García, M. Á. (2008). Use of selected flowering plants in greenhouses to enhance aphidophagous hoverfly populations (Diptera: Syrphidae). Ann. Soc. Entomol. France 44, 487-492. doi: 10.1080/00379271.2008.10697584

Pirayeshfar, F., Safavi, S. A., Sarraf Moayeri, H. R., and Messelink, G. J. (2020). The potential of highly nutritious frozen stages of Tyrophagus putrescentiae as a supplemental food source for the predatory mite Amblyseius swirskii. Biocontrol Sci. Technol. 30, 403-417. doi: 10.1080/09583157.2020.1722798

Polis, G. A., and Holt, R. D. (1992). Intraguild predation: the dynamics of complex trophic interactions. Trends Ecol. Evol. 7, 151-154. doi: 10.1016/0169-5347(92)90208-S

Polis, G. A., Myers, C. A., and Holt, R. D. (1989). The ecology and evolution of intraguild predation: potential competitors that eat each other. Annu. Rev. Ecol. S 20, 297-330. doi: 10.1146/annurev.es.20.110189.001501

Popenoe, J., and Osborne, L. (2010). Rose nursery banker plants. Proc. Fla. State Hort. Soc. 123, 296-297.

Portillo, N., Alomar, O., and Wäckers, F. (2012). Nectarivory by the planttissue feeding predator Macrolophus pygmaeus Rambur (Heteroptera: Miridae): Nutritional redundancy or nutritional benefit? J. Insect Physiol. 58, 397-401. doi: 10.1016/j.jinsphys.2011.12.013

Prabhaker, N., Castle, S. J., Naranjo, S. E., Toscano, N. C., and Morse, J. G. (2011). Compatibility of two systemic neonicotinoids, imidacloprid and thiamethoxam, with various natural enemies of agricultural pests. J. Econ. Entomol. 104, 773-781. doi: 10.1603/EC10362

Prado, S. G., and Frank, S. D. (2014). Optimal foraging by an aphid parasitoid affects the outcome of apparent competition. Ecol. Entomol. 39, 236-244. doi: 10.1111/een.12093

Prado, S. G., Jandricic, S. E., and Frank, S. D. (2015). Ecological interactions affecting the efficacy of Aphidius colemani in greenhouse crops. Insects 6, 538-575. doi: 10.3390/insects6020538

Pratt, P. D., and Croft, B. A. (2000). Banker plants: evaluation of release strategies for predatory mites. J. Environ. Hort. 18, 211-217. doi: 10.24266/0738-2898-18.4.211

Preverieri, G., Simoni, S., and Liguori, M. (2006). Suitability of Quercus ilex pollen for rearing four species of phytoseiid mites (Acari: Phytoseiidae). Redia. Frienze $89,65-71$.

Price, P. W., Bouton, C. E., Gross, P., McPheron, B. A., Thompson, J. N., and Weis, A. E. (1980). Interactions among three trophic levels: influence of plants on interactions between insect herbivores and natural enemies. Annu. Rev. Ecol. S 11, 41-65. doi: 10.1146/annurev.es.11.110180.000353

Pumariño, L., and Alomar, O. (2012). The role of omnivory in the conservation of predators: Orius majusculus (Heteroptera: Anthocoridae) on sweet alyssum. Biol. Control 62, 24-28. doi: 10.1016/j.biocontrol.2012.03.007

Pumariño, L., and Alomar, O. (2014). Assessing the use of Lobularia maritima as an insectary plant for the conservation of Orius majusculus and biological control of Frankliniella occidentalis. IOBC/WPRS Bull. 100, 113-116.

Put, K., Bollens, T., Wäckers, F., and Pekas, A. (2015). Non-target effects of commonly used plant protection products in roses on the predatory mite Euseius gallicus Kreiter \& Tixier (Acari: Phytoseidae). Pest Manag. Sci. 72, 1373-1380. doi: 10.1002/ps.4162

Put, K., Bollens, T., Wäckers, F. L., and Pekas, A. (2012). Type and spatial distribution of food supplements impact population development and dispersal 
of the omnivore predator Macrolophus pygmaeus (Rambur) (Hemiptera: Miridae). Biol. Control 63, 172-180. doi: 10.1016/j.biocontrol.2012.06.011

Rabie, A. L., Wells, J. D., and Dent, L. K. (1983). The nitrogen content of pollen protein. J. Apic. Res. 22, 119-123. doi: 10.1080/00218839.1983. 11100572

Ragusa, E., Tsolakis, H., and Palomero, R. J. (2009). Effect of pollens and preys on various biological parameters of the generalist mite Cydnodromus californicus. Bull. Insect. 62, 153-158.

Ragusa, S., Vargas, R., Tsolakis, H., and Ashbach, R. (2000). Laboratory studies on the influence of various food substances on some biological and life-table parameters of Cydnodromus picanus Ragusa (Parasitiformes, Phytoseiidae) associated with citrus trees in the Chilean desert. Phytophaga 10, 11-23.

Ramakers, P., and van Lieburg, M. (1982). Start of commercial production and introduction of Amblyseius mckenziei Sch. and Pr. (Acarina: Phytoseiidae) for the control of Thrips tabaci Lind (Thysanoptera: Thripidae) in glasshouses, Med. Fac. Landbouww. Univ. Gent 47, 541-545.

Ramakers, P. M. J. (1990). Manipulation of phytoseiid thrips predators in the absence of thrips. IOBC SROP Bull. 13, 169-172.

Ramakers, P. M. J. (1995). "Biological control using oligophagous predators," in Thrips biology and management. eds B. L Parker, M. Skinner, and T Lewis (New York, NY: Plenum Press) 225-229. doi: 10.1007/978-1-4899-1409-5_33

Ramakers, P. M. J., and Maaswinkel, R. H. M. (2002). Pest occurrence and control in organic year-round production of chrysanthemums. IOBC/WPRS Bull. 25, 221-224.

Ramakers, P. M. J., and Voet, S. J. P. (1995). Use of castor bean, Ricinus communis, for the introduction of the thrips predator Amblyseius degenerans on glasshouse-grown sweet peppers. Med. Fac. Landbouww. Univ. Gent. $60,885-891$.

Ranabhat, N. B., Goleva, I., and Zebitz, C. P. (2014). Life tables of Neoseiulus cucumeris exclusively fed with seven different pollens. Biocontrol 59, 195-203. doi: 10.1007/s10526-013-9556-5

Rasmy, A. H., and El-Banhawy, E. M. (1975). Biology and predatory efficiency of two phytoseiid mites as affected by long-term pollen feeding. Entomophaga 20, 93-95. doi: 10.1007/BF02373454

Rezaie, M. (2017). Effect of three pollen grains on life table parameters of Neoseiulus californicus (Acari: Phytoseiidae). Int. J. Engin. Appl. Sci. 4, 2394-3661.

Rezaie, M., and Askarieh, S. (2016). Effect of different pollen grains on life table parameters of Neoseiulus barkeri (Acari: Phytoseiidae). Persian J. Acarol. 5. doi: 10.22073/pja.v5i3.19532

Richards, P. C. (1992). Mass production of the insidious pirate bug for control of the western flower thrips in greenhouses (M.Sc. thesis). Department of Environmental Biology, University of Guelph, Guelph, ON, United States.

Richards, P. C., and Schmidt, J. M. (1995). The suitability of some natural and artificial substrates for oviposition by Orius insidiosus. Entomol. Exp. Appl. 80, 325-333. doi: 10.1111/j.1570-7458.1996.tb00945.x

Richards, P. C., and Schmidt, J. M. (1996). The effects of selected dietary supplements on survival and reproduction of Orius insidiosus (Say) (Hemiptera: Anthocoridae). Can. Entomol. 128, 171-176. doi: 10.4039/Ent128171-2

Riddick, E. W. (2009). Benefits and limitations of factitious prey and artificial diets on life parameters of predatory beetles, bugs, and lacewings: a mini-review. Biocontrol 54, 325-339. doi: 10.1007/s10526-008-9171-z

Riddick, E. W., and Wu, Z. (2015). Does a change from whole to powdered food (Artemia franciscana eggs) increase oviposition in the ladybird Coleomegilla maculata? Insects 6, 815-826. doi: 10.3390/insects6040815

Ridgway, R. L., and Jones, S. L. (1968). Plant feeding by Geocoris pallens and Nabis americoferus. Ann. Entomol. Soc. Am. 61, 232-233. doi: 10.1093/aesa/ 61.1.232

Ridray, G., Sasseau, E., and Trottin-Caudal, Y. (2001). Une stratégie innovante: l'introduction en pépinière de Macrolophus caliginosus. Suppl. PHM $428,16-19$.

Riudavets, J., Arnó, J., and Castañé, C. (2006). Rearing predatory bugs with the brine shrimp Artemia sp. as alternative prey food. IOBC/WPRS Bull. 29, 235-240.

Rivest, S., and Forrest, J. R. (2020). Defence compounds in pollen: why do they occur and how do they affect the ecology and evolution of bees? New Phytol. 225, 1053-1064. doi: 10.1111/nph.16230
Roda, A., Nyrop, J., Dicke, M., and English-Loeb, G. (2000). Trichomes and spidermite webbing protect predatory mite eggs from intraguild predation. Oecologia 125, 428-435. doi: 10.1007/s004420000462

Roda, A., Nyrop, J., English-Loeb, G., and Dicke, M. (2001). Leaf pubescence and two-spotted spider mite webbing influence phytoseiid behavior and population density. Oecologia 129, 551-560. doi: 10.1007/s004420100762

Rodrigues, S. M., and Bueno, V. H. (2001). Parasitism rates of Lysiphlebus testaceipes (Cresson) (Hym.: Aphidiidae) on Schizaphis graminum (Rond.) and Aphis gossypii Glover (Hem.: Aphididae). Neotrop. Entomol. 30, 625-629. doi: 10.1590/S1519-566X2001000400017

Rodríguez-Cruz, F. A., Venzon, M., and Pinto, C. M. F. (2013). Performance of Amblyseius herbicolus on broad mites and on castor bean and sunnhemp pollen. Exp. Appl. Acarol. 60, 497-507. doi: 10.1007/s10493-013-9665-y

Romeih, A. H. M., El-Saidy, E. M. A., and El-Arnaouty, S. A. (2004). Suitability of Ephestia kuehniella and Corycera cephalonica eggs as alternative preys for rearing predatory mites. Egypt. J. Biol. Pest Control 14, 101-105. doi: 10.1007/s10343-015-0350-4

Romero, G. Q., and Benson, W. W. (2004). Leaf domatia mediate mutualism between mites and a tropical tree. Oecologia 140, 609-616. doi: $10.1007 / \mathrm{s} 00442-004-1626-\mathrm{z}$

Romero, G. Q., and Benson, W. W. (2005). Biotic interactions of mites, plants and leaf domatia. Curr. Opin. Plant Biol. 8, 436-440. doi: 10.1016/j.pbi.2005.05.006

Roulston, T. H., and Cane, J. H. (2000). Pollen nutritional content and digestibility for animals. Pl. Syst. Evol 222, 187-209. doi: 10.1007/BF00984102

Rozario S. A. (1995) Association between mites and leaf domatia: evidence from Bangladesh, South Asia. J. Trop. Ecol. 11, 99-108. doi: $10.1017 /$ S0266467400008440

Rozario, S. A. (1994). Domatia and mites: effects of leaf morphology on beneficial mites in semi-natural and managed systems [Doctoral dissertation]. Monash University. Retrieved from: https://catalogue.nla.gov.au/Record/ 2275037 (accessed June 2020).

Rueda-Ramírez, D., Rios-Malaver, D., Varela-Ramírez, A., and De Moraes, G. J. (2018). Colombian population of the mite Gaeolaelaps aculeifer as a predator of the thrips Frankliniella occidentalis and the possible use of an astigmatid mite as its factitious prey. Syst. Appl. Acarol. 23, 2359-2372. doi: 10.11158/saa.23.12.8

Rumei, X. (1991). Improvements of the plant-pest-parasitoid (PPP) model and its application on whitefly-encarsia population dynamics under different release methods. J. Appl. Entomol. 112, 274-287. doi: 10.1111/j.1439-0418.1991.tb01057.x

Sabelis, M. W., Janssen, A., Bruin, J., Bakker, F. M., Drukker, B., Scutareanu, P., et al. (1999). "Interactions between arthropod predators and plants: a conspiracy against herbivorous arthropods?," in Ecology and Evolution of the Acari (Dordrecht: Springer), 207-229.

Sabelis, M. W., and van Rijn, P. C. (2006). When does alternative food promote biological pest control? IOBC/WPRS Bull. 29:195.

Saber, S. A. (2012). Biological aspects and life table parameters of the predacious mite, Neoseiulus californicus (McGregor) (Acari: Phytoseiidae) consuming food types during immature stages and after adult emergence. Arch. Phytopathol. Pflanzenschutz 45, 2494-2501. doi: 10.1080/03235408.2012.730887

Saber, S. A. (2013). Survival, fecundity and reproductive recovery period of Neoseiulus californicus (McGregor) during long-term preservation on maize pollen and after switch to Tetranychus urticae Koch. Arch. Phytopathol. Pflanzenschutz 46, 789-795. doi: 10.1080/03235408.2012.752144

Sade, A., Steinberg, S., Salinger-Bubnov, M., Gilboa, E., Klempert, G., Roitman, N., et al. (2019). Improved western flower thrips control through artemiabased early introduction of Orius laevigatus in commercial pepper greenhouses. IOBC/WPRS Bull. 147, 39-46.

Saito, Y., and Mori, H. (1975). The Effects of Pollen as an Alternative Food for Three Species of Phytoseiid Mites (Acarina: Phytoseiidae). Memoirs of the Faculty of Agriculture-Hokkaido University, 236-246.

Saito, M. (2005). Control of cotton aphid, Aphis gossypii, on greenhouse-raised cucumber by releasing Aphidius colemani on banker plants. Annu. Rep. Soc. Plant Prot. North Jpn 56, 137-140.

Salamero, A., Gabarra, R., and Albajes, R. (1987). Observations on the predatory and phytophagous habits of Dicyphus tamaninii Wagner (Heteroptera: Miridae). IOBC/WPRS Bull. 10, 165-169.

Salas-Aguilar, J., and Ehler, L. E. (1977). Feeding habits of Orius tristicolor. Ann. Entomol. Soc. Am. 70, 60-62. doi: 10.1093/aesa/70.1.60 
Samaras, K., Pappas, M. L., Fytas, E., and Broufas, G. D. (2015). Pollen suitability for the development and reproduction of Amblydromalus limonicus (Acari: Phytoseiidae). Biocontrol 60, 773-782. doi: 10.1007/s10526-015-9680-5

Sampson, C. (1998). The Commercial Development of an Amblyseius cucumeris Controlled Release Method for the Control of Frankliniella occidentalis in Protected Crops. North Yorkshire: Horticulture Research International, Stockbridge House, Cawood, 409-416.

Sánchez, E., del Mar Morales, M., Parra, A., Belén Arévalo, A., and Vila, E. (2019). Development of releasing systems of astigmatid mites for the improvement of biological control. IOBC/WPRS Bull. 147:36.

Sanchez, J. A., Gillespie, D. R., and McGregor, R. R. (2003). The effects of mullein plants (Verbascum thapsus) on the population dynamics of Dicyphus hesperus (Heteroptera: Miridae) in tomato greenhouses. Biol. Control 28, 313-319. doi: 10.1016/S1049-9644(03)00116-6

Sanchez, J. A., Gillespie, D. R., and McGregor, R. R. (2004). Plant preference in relation to life history traits in the zoophytophagous predator Dicyphus hesperus. Entomol. Exp. Appl. 112, 7-19. doi: 10.1111/j.0013-8703.2004.00174.x

Schausberger, P. (1997). Inter-and intraspecific predation on immatures by adult females in Euseius finlandicus, Typhlodromus pyri and Kampimodromus aberrans (Acari: Phytoseiidae). Exp. Appl. Acarol. 21, 131-150. doi: 10.1023/A:1018478418010

Schmidt, J. M., Richards, P. C., Nadel, H., and Ferguson, G. (1995). A rearing method for the production of large numbers of the insidious flower bug, Orius insidiosus (Say) (Hemiptera: Anthocoridae). Can. Entomol. 127, 445-447. doi: 10.4039/Ent127445-3

Schmidt, J. O., Buchmann, S. L., and Glaum, M. (1989). The nutritional value of Typha latifolia pollen for bees. J. Apicult. Res. 28, 155-165. doi: 10.1080/00218839.1989.11100838

Schmidt, U. (1996). Open culture from Encarsia formosa on tobacco plants. Offene Zucht van Encarsia formosa auf Tabakpflanzen. Gemuse 32, 164-167.

Schneider, F. (1948). Beitrag zur Kenntnis der generationsverhältnisse und diapause räuberischer schwebfliegen (Syrphiden Dipt.). Mitt. Schweiz, Ent. Ges. 21, 249-285.

Schoen, L. (2003). "La sauvegarde d'une population de Macrolophus caliginosus (Wagner) à l'aide de plantes relais dans une culture de tomate de serre," in Colloque International Tomate Sous Abri, Protection Intégrée-Agriculture Biologique, Avignon, France, 17-18 et 19 Septembre 2003, eds L. Roche, M. Edin, V. Mathieu, F. Laurens (Paris: Centre Technique Interprofessionnel des Fruits et Légumes), 139-142.

Schoen, L., and Martin, C. (1997). "Controle du puceron Aphis gossypii Glover en culture de melon sous abri par le systeme des plantes relais avec Aphidus colemani en Roussillon (sud France)," International Conference on Pests in Agriculture, 6 January, 1997. at le Corum, Montpellier, France (Paris: Association Nationale pour la Protection des Plantes (ANPP)), 759-765.

Schoen, L. (2000). The use of open rearing units or "bankerplants" against Aphis gossypii Glover in protected courgette and melon crops in Roussillon (South of France). IOBC/WPRS Bull. 23, 181-186.

Seelmann, L., Auer, A., Hoffmann, D., and Schausberger, P. (2007). Leaf pubescence mediates intraguild predation between predatory mites. Oikos. 116, 807-817. doi: 10.1111/j.0030-1299.2007.15895.x

Seko, T., Abe, J., and Miura, K. (2019). Effect of supplementary food containing Artemia salina on the development and survival of flightless Harmonia axyridis in greenhouses. Biocontrol 64, 333-341. doi: 10.1007/s10526-01909935-3

Sengonça, C., Saleh, A., and Blasse, R. P. (2003). Investigations on the potential damage caused to cucumber fruit by the polyphagous predatory bug Dicyphus tamaninii Wagner (Heteroptera: Miridae) under different nutritional conditions. J. Plant Dis Protect 110, 59-65.

Settle, W. H., Ariawan, H., Astuti, E. T., Cahyana, W., Hakim, A. L., Hindayana, D., et al. (1996). Managing tropical rice pests through conservation of generalist natural enemies and alternative prey. Ecology 77, 1975-1988. doi: $10.2307 / 2265694$

Shakya, S., Weintraub, P. G., and Coll, M. (2009). Effect of pollen supplement on intraguild predatory interactions between two omnivores: the importance of spatial dynamics. Biol. Control 50, 281-287. doi: 10.1016/j.biocontrol.2009.04.012

Shenoy, M., and Borges, R. M. (2010). Geographical variation in an ant-plant interaction correlates with domatia occupancy, local ant diversity, and interlopers. Biol. J. Linn. Soc., 100, 538-551. doi: 10.1111/j.1095-8312.2010.01459.x

Sinia, A., Roitberg, B., McGregor, R. R., and Gillespie, D. R. (2004). Prey feeding increases water stress in the omnivorous predator Dicyphus hesperus. Entomol. Exp. Appl. 110, 243-248. doi: 10.1111/j.0013-8703.2004.00145.x

Skirvin, D., Kravar-Garde, L., Reynolds, K., Jones, J., and De Courcy Williams, M. (2006). The influence of pollen on combining predators to control Frankliniella occidentalis in ornamental chrysanthemum crops. Biocontrol Sci. Technol. 16, 99-105. doi: 10.1080/09583150500258636

Skirvin, D. J., and Fenlon, J. S. (2001). Plant species modifies the functional response of Phytoseiulus persimilis (Acari: Phytoseiidae) to Tetranychus urticae (Acari: Tetranychidae): implications for biological control. B. Entomol. Res. 91, 61-67.

Skirvin, D. J., Kravar-Garde, L., Reynolds, K., Jones, J., Mead, A., and Fenlon, J. (2007). Supplemental food affects thrips predation and movement of Orius laevigatus (Hemiptera: Anthocoridae) and Neoseiulus cucumeris (Acari: Phytoseiidae). B. Entomol. Res. 97, 309-315. doi: 10.1017/S0007485307005007

Smith, B. C. (1960a). A technique for rearing coccinellid beetles on dry foods, and influence of various pollens on the development of Coleomegilla maculata legni Timb (Coleoptera: Coccinellidae). Ca. J. Zool. 38, 1047-1049. doi: 10.1139/z60-109

Smith, B. C. (1960b). Results of rearing some coccinellid (Coleoptera: Coccinellidae) larvae on various pollens. Proc. Entomol. Soc. Ont. 91, 270-271.

Smith, S. F., and Krischik, V. A. (1999). Effects of systemic imidacloprid on Coleomegilla maculata (Coleoptera: Coccinellidae). Environ. Entomol. 28, 1189-1195. doi: 10.1093/ee/28.6.1189

Soltaniyan, A., Kheradmand, K., Fathipour, Y., and Shirdel, D. (2018). Suitability of pollen from different plant species as alternative food sources for Neoseiulus californicus (Acari: Phytoseiidae) in comparison with a natural prey. J. Econ. Entomol. 111, 2046-2052. doi: 10.1093/jee/toy172

Somerville, D. C., and Nicol, H. I. (2006). Crude protein and amino acid composition of honey bee-collected pollen pellets from south-east Australia and a note on laboratory disparity. Aust. J. Exp. Agric. 46, 141-149. doi: 10.1071/EA03188

Song, B., Yang, Q., Xin, T., Li, Q., Jiang, C., and Wang, H. (2018). Effects of Tyrophagus putrescentiae Plus Pollen on Development and Reproduction of Orius minutus (Hemiptera: Anthocoridae). Chin. J. Biol. Control 34, 220-225.

Speyer, E. R. (1927). An important parasite of the greenhouse whitefly. Bull. Ent. Res. 27, 301-308.

Stacey, D. L. (1977). 'Banker' plant production of Encarsia formosa Gahan and its use in the control of glasshouse whitefly on tomatoes. Plant Pathol. 26, 63-66.

Standifer, L. N., Devys, M., and Barbier, M. (1968). Pollen sterols - a mass spectrographic survey. Phytochemistry 7, 1361-65. doi: 10.1016/S0031-9422(00)85638-1

Stanley, R. G., and Linskens, H. F. (1974). -Pollen. Biology Biochemistry Management. Berlin; Heidelberg: Springer.

Starý, P. (1969). Biology of Aphid Parasites (Hymenoptera: Aphidiidae) with respect to integrated control. Anz. Schädl. Kd. 42, 92-192. doi: $10.1007 / \mathrm{BF} 02330200$

Starý, P. (1993). Alternative host and parasitoid in first method in aphid pest management in glasshouses, J. Appl. Entomol. 116, 187-191. doi: 10.1111/j.1439-0418.1993.tb01187.x

Stelzl, M. (1991). Investigations on food of Neuroptera-adults (Neuropteroidea, Insecta) in Central Europe. With a short discussion of their role as natural enemies of insect pests. J. Appl. Entomol. 111, 469-477. doi: 10.1111/j.1439-0418.1991.tb00349.x

Stinner, R. E. (1977). Efficacy of inundative releases. Ann. Rev. Entomol. 22, 515-531. doi: 10.1146/annurev.en.22.010177.002503

Stout, M. J., Workman, K. V., Bostock, R. M., and Duffey, S. S. (1997). Specificity of induced resistance in the tomato, Lycopersicon esculentum. Oecologia 113, 74-81. doi: 10.1007/s004420050355

Su, J., Dong, F., Liu, S. M., Lu, Y. H., and Zhang, J. P. (2019). Productivity of Neoseiulus bicaudus (Acari: Phytoseiidae) reared on natural prey, alternative prey, and artificial diet. J. Econ. Entomol. 112, 2604-2613. doi: $10.1093 /$ jee/toz202

Sun, H., and Song, Y. (2019). Establishment of a wheat banker plant system for the parasitoid Aphidius gifuensis against Myzus persicae in greenhouse chili pepper. Appl. Entomol. Zool. 54, 339-347. doi: 10.1007/s13355-019-00624-2 
Sun, H. Z., Wang, X. D., Chen, Y. G., Wang, H. T., Li, S. J., and Song, Y. Q. (2017). Wheat and barley as banker plant in the mass production of Aphidius gifuensis Ashmead (Hymenoptera: Braconidae) parasitizing Schizaphis graminum Rondani (Homoptera: Aphididae). J. Plant Dis. Prot. 124, 305-311. doi: 10.1007/s41348-016-0059-3

Swirski, E. (1967). Laboratory studies on the feeding, development and oviposition of the predaceous mite Typhlodromus athiasae P. and S. (Acarina: Phytoseiidae) on various kinds of food substances. Israel J. Agric. Res. 17, 213-218.

Tanigoshi, L. K., Mégevand, B., and Yaninek, J. S. (1993). Non-prey food for subsistence of Amblyseius idaeus (Acari: Phytoseiidae) on cassava in Africa. Exp. Appl. Acarol. 17, 91-96.

Tavella, L., and Arzone, A. (1996). "Development of Macrolophus caliginosus and Dicyphus errans reared on different diets (Rhynchota Miridae)," in Proceedings of the XXth International Congress on Entomology. Tipografia TAF srl (Firenze).

Tena, A., Pekas, A., Cano, D., Wäckers, F. L., and Urbaneja, A. (2015). Sugar provisioning maximizes the biocontrol service of parasitoids. J. Appl. Ecol. 52, 795-804. doi: 10.1111/1365-2664.12426

Todd, F. E., and Bretherick, O. (1942). The composition of pollens. J. Econ. Entomol. 35, 312-317. doi: 10.1093/jee/35.3.312

Tommasini, M. G., and Nicoli, G. (1993). Adult activity of four Orius species reared on two preys. IOBC/WPRS Bull. 16, 181-184.

Tuovinen, T., and Lindqvist, I. (2010). Maintenance of predatory phytoseiid mites for preventive control of strawberry tarsonemid mite Phytonemus pallidus in strawberry plant propagation. Biol. Control 54, 119-125. doi: 10.1016/j.biocontrol.2010.04.006

Turlings, T. C., Tumlinson, J. H., and Lewis, W. J. (1990). Exploitation of herbivore-induced plant odors by host-seeking parasitic wasps. Science 250, 1251-1253. doi: 10.1126/science.250.4985.1251

Turlings, T. C. J., and Wäckers, F. L. (2004). Recruitment of predators and parasitoids by herbivore-damaged plants. in Advances in Insect Chemical Ecology. eds R. T. Carde and J. G. Miller (New York, NY: Cambridge University Press), 21-75.

Vacante, V., Cocuzza, G. E., De Clercq, P., Van De Veire, M., and Tirry, L. (1997). Development and survival of Orius albidipennis and O. laevigatus (Het.: Anthocoridae) on various diets. Entomophaga 42:493. doi: 10.1007/BF02769809

Valentin, R. (2011, March 4). Using banker plants in an IPM program. Greenhouse Management (2011).

Valentin, R. (2017). Using biological control as a first line of defence from 'Start to Finish' in greenhouse vegetables and ornamental production. IOBC/WPRS Bull. 124, 152-156.

Van den Meiracker, R. A. F., and Ramakers, P. M. J. (1991). Biological control of the western flower thrips, Frankliniella occidentalis, in sweet pepper, with the anthocorid predator, Orius insidiosus. Med. Fac. Landbouww. Univ. Gent 56, 241-249.

Van der Linden, A. (1992). Phytomyza caulinaris Hering, an alternative host for the development of an open rearing system for parasitoids of Liriomyza species. Proc. Exper. Appl. Entomol. Neth. Entomol. Soc. 3, 31-39.

Van der Linden, A., and van der Staaij, M. (2001). Banker plants facilitate biological control of whiteflies in cucumber. Proc. Exper. Appl. Entomol., Neth. Entomol. Soc $12,75-80$.

Van Driesche, R. G., Lyon, S., Sanderson, J. P., Bennett, K. C., Stanek, E. J., and Zhang, R. (2008). Greenhouse trials of Aphidius colemani (Hymenoptera: Braconidae) banker plants for control of aphids (Hemiptera: Aphididae) in greenhouse spring floral crops. Fla. Entomol. 91, 583-591. doi: 10.1653/0015-4040-91.4.583

Van Holstein, R., and Messelink, G. J. (2014). Verbetering inzet Macrolophus pygmaeus in tomaat. Report Wageningen UR Glastuinbouw.

Van Houten, Y. M., Glas, J. J., Hoogerbrugge, H., Rothe, J., Bolckmans, K. J. F., Simoni, S., et al. (2013). Herbivory-associated degradation of tomato trichomes and its impact on biological control of Aculops lycopersici. Exp. Appl. Acarol. 60, 127-138. doi: 10.1007/s10493-01 2-9638-6

Van Lenteren, J. C., Babendreier, D., Bigler, F., Burgio, G., Hokkanen, H. M. T., Kuske, S., et al. (2003). Environmental risk assessment of exotic natural enemies used in inundative biological control. BioControl 48, 3-38. doi: 10.1023/A:1021262931608

Van Lenteren, J. C., and Tommasini, M. G. (2003). "Mass production, storage, shipment and release of natural enemies," in Quality Control and Production of Biological Control Agents, Theory and Testing Procedures (Wallingford, CT: CAB International), 181-189.

Van Rijn, P. C., and Wäckers, F. L. (2016). Nectar accessibility determines fitness, flower choice and abundance of hoverflies that provide natural pest control. $J$. Appl. Ecol. 53, 925-933. doi: 10.1111/1365-2664.12605

Van Rijn, P. C. J., and Sabelis, M. W. (1990). Pollen as an alternative food source for predatory mites and its effect on the biological control of thrips in greenhouses. In Proc. Exper. Appl. Entomol. 1, 44-48.

Van Rijn, P. C. J., and Sabelis, M. W. (1993). Does alternative food always enhance biological control? The effect of pollen on the interaction between western flower thrips and its predators [Amblyseius cucumeris]. OILB SROP Bull. 16, 123-125.

Van Rijn, P. C. J., and Tanigoshi, L. K. (1999a). Pollen as food for the predatory mites Iphiseius degenerans and Neoseiulus cucumeris (Acari: Phytoseiidae): dietary range and life history. Exp. Appl. Acarol. 23, 785-802. doi: 10.1023/A:1006227704122

Van Rijn, P. C. J., and Tanigoshi, L. K. (1999b). The contribution of extrafloral nectar to survival and reproduction of the predatory mite Iphiseius degenerans on Ricinus communis. Exp. Appl. Acarol. 23, 281-296. doi: 10.1007/978-94-017-1343-6_31

Van Rijn, P. C. J., van Houten, Y. M., and Sabelis, M. W. (1999). Pollen improves thrips control with predatory mites. IOBC/WPRS Bull. 22, 209-212.

Van Rijn, P. C. J., van Houten, Y. M., and Sabelis, M. W. (2002). How plants benefit from providing food to predators even when it is also edible to herbivores. Ecology 83, 2664-2679. doi: 10.1890/0012-9658(2002)0832664:HPBFPF2.0.CO;2

Van Schelt, J. (1999). Biological control of sweet pepper pests in the Netherlands. IOBC/WPRS Bull. 22, 217-220.

Van Schelt, J., Tetteroo, A., Hoogerbrugge, H., Veenman, R., and Bolckmans, K. (2008). The release of beneficials in greenhouses with an air blower, a new wind in biocontrol. IOBC/WPRS Bull. 32, 245-248.

Vandekerkhove, B., and De Clercq, P. (2010). Pollen as an alternative or supplementary food for the mirid predator Macrolophus pygmaeus. Biol. Control 53, 238-242. doi: 10.1016/j.biocontrol.2010.01.005

Vandekerkhove, B., Parmentier, L., Van Stappen, G., Grenier, S., Febvay, G., Rey, M., et al. (2009). Artemia cysts as an alternative food for the predatory bug Macrolophus pygmaeus. J. Appl. Entomol. 133, 133-142. doi: 10.1111/j.1439-0418.2008.01332.x

Vandekerkhove, B., Van Baal, E., Bolckmans, K., and De Clercq, P. (2006). Effect of diet and mating status on ovarian development and oviposition in the polyphagous predator Macrolophus caliginosus (Heteroptera: Miridae). Biol. Control 39, 532-538. doi: 10.1016/j.biocontrol.2006.06.002

Vangansbeke, D., Nguyen, D. T., Audenaert, J., Gobin, B., Tirry, L., and De Clercq, P. (2016a). Establishment of Amblyseius swirskii in greenhouse crops using food supplements. Syst. Appl. Acarol. 21, 1174-1184. doi: 10.11158/saa.21.9.2

Vangansbeke, D., Nguyen, D. T., Audenaert, J., Verhoeven, R., Deforce, K., Gobin, B., et al. (2014a). Diet-dependent cannibalism in the omnivorous phytoseiid mite Amblydromalus limonicus. Biol. Control 74, 30-35. doi: 10.1016/j.biocontrol.2014.03.015

Vangansbeke, D., Nguyen, D. T., Audenaert, J., Verhoeven, R., Gobin, B., Tirry, L., et al. (2014b). Food supplementation affects interactions between a phytoseiid predator and its omnivorous prey. Biol. Control 76, 95-100. doi: 10.1016/j.biocontrol.2014.06.001

Vangansbeke, D., Nguyen, D. T., Audenaert, J., Verhoeven, R., Gobin, B., Tirry, L., et al. (2014c). Performance of the predatory mite Amblydromalus limonicus on factitious foods. Biocontrol 59, 67-77. doi: 10.1007/s10526-013-9548-5

Vangansbeke, D., Nguyen, D. T., Audenaert, J., Verhoeven, R., Gobin, B., Tirry, L., et al. (2016b). Supplemental food for Amblyseius swirskii in the control of thrips: feeding friend or foe? Pest Manag. Sci. 72, 466-473. doi: 10.1002/ps.4000

Vantornhout, I., Minnaert, H., and Tirry, L. (2004). Effect of pollen, natural prey and factitious prey on the development of Iphiseius degenerans. Biocontrol 49, 627-644. doi: 10.1007/s10526-004-5280-5

Vergniaud, P. (1997). Lutte biologique sous abri: les plantes relais contre Aphis gossypii. PHM Revue Horticole 384, 44-45.

Vieira Marques, R., Almeida Sarmento, R., Alves Ferreira, V., Venzon, M., Lemos, F., Pedro-Neto, M. et al. (2014). Alternative food sources to predatory mites (Acari) in a Jatropha curcas (Euphorbiaceae) crop. Rev. Colomb. Entomol. 40, 74-79. 
Vila, E. (2004). Refugis vegetals en la conservació de mírids depredadors [Ph.D. Thesis]. Universitat de Lleida, Lleida, Spain.

Vila, E., del Mar Morales, M., and Parra, A. (2017). Prey mites as an in-crop food: an innovative strategy to enhance biocontrol on chrysanthemums. IOBC/WPRS Bull. 124, 178-183.

Villanueva, R. T., and Childers, C. C. (2004). Phytoseiidae increase with pollen deposition on citrus leaves. Fla. Entomol. 87, 609-611. doi: 10.1653/0015-4040(2004)0870609:PIWPDO2.0.CO;2

Wäckers, F. L. (1999). Gustatory response by the hymenopteran parasitoid Cotesia glomerata to a range of nectar and honeydew sugars. J. Chem. Ecol. 25, 2863-2876. doi: 10.1023/A:1020868027970

Wäckers, F. L. (2000). Do oligosaccharides reduce the suitability of honeydew for predators and parasitoids? A further facet to the function of insect-synthesized honeydew sugars. Oikos 90, 197-201. doi: 10.1034/j.1600-0706.2000.900124.x

Wäckers, F. L. (2001). A comparison of nectar-and honeydew sugars with respect to their utilization by the hymenopteran parasitoid Cotesia glomerata. J. Insect Physiol. 47, 1077-1084. doi: 10.1016/S0022-1910(01)00088-9

Wäckers, F. L. (2005). "Suitability of (extra-) floral nectar, pollen, and honeydew as insect food. Plant-provided food for carnivorous insects: a protective mutualism and its applications," in Plant-Provided Food for Carnivorous Insects: A Protective Mutualism and Its Applications, eds Jan Bruin, P. C. J. van Rijn, and F. L. Wäckers (Cambridge: Cambridge University Press), 17-76.

Wäckers, F. L., and Bonifay, C. (2004). How to be sweet? Extrafloral nectar allocation by Gossypium hirsutum fits optimal defense theory predictions. Ecology 85, 1512-1518. doi: 10.1890/03-0422

Wäckers, F. L., Romeis, J., and van Rijn, P. (2007). Nectar and pollen feeding by insect herbivores and implications for multitrophic interactions. Annu. Rev. Entomol. 52, 301-323. doi: 10.1146/annurev.ento.52.110405.091352

Wäckers, F. L., and Steppuhn, A. (2003). Characterizing nutritional state and food source use of parasitoids collected in fields with high and low nectar availability. IOBC/WPRS Bull. 26, 203-208.

Wäckers, F. L., and van Rijn, P. C. (2005). "Food for protection: an introduction," in Plant-Provided Food for Carnivorous Insects: A Protective Mutualism and Its Applications, eds Jan Bruin, P. C. J. van Rijn, and F. L. Wäckers (Cambridge: Cambridge University Press), 1-14.

Wäckers, F. L., van Rijn, P. C., and Heimpel, G. E. (2008). Honeydew as a food source for natural enemies: making the best of a bad meal? Biol. Control 45, 176-184. doi: 10.1016/j.biocontrol.2008.01.007

Wäckers, F. L., and van Rijn, P. C. J. (2012). "Pick and Mix: selecting flowering plants to meet the equirements of target biological control insects," in Biodiversity and Insect Pests: Key Issues for Sustainable Management. eds G. M. Gurr, S. D. Wratten, W. E. Snyder, D. M. Y. Read (Chichester: Wiley), 139-165.

Wäckers, F. L., van Rijn, P. C. J., and Bruin, J. (2005). Plant-Provided Food for Carnivorous Insects: a Protective Mutualism and Its Applications. Cambridge: Cambridge University Press, 10-348.

Wade, M. R., Zalucki, M. P., Wratten, S. D., and Robinson, K. A. (2008). Conservation biological control of arthropods using artificial food sprays: current status and future challenges. Biol. Contr. 45, 185-199. doi: 10.1016/j.biocontrol.2007.10.024

Waite, G. K. (2001). "Managing spider mites in field-grown strawberries using Phytoseiulus persimilis and the 'pest-in-first' technique," in Acarology: Proc. 10th Int. Congr. eds R. B. Halliday, D. E. Walter, H. C. Proctor, R. A. Norton, and M. J. Colloff (Collingwood, VIC: CSIRO Publishing) ,381-386.

Waite, M. O. (2012). New strategies to improve the efficiency of the biological control agent, Orius insidiosus (Say), in greenhouse ornamental crops [M.Sc. thesis], University of Guelph, Guelph, ON, Canada.

Waite, M. O., Scott-Dupree, C. D., Brownbridge, M., Buitenhuis, R., and Murphy, G. (2014). Evaluation of seven plant species/cultivars for their suitability as banker plants for Orius insidiosus (Say). Biocontrol 59, 79-87. doi: 10.1007/s10526-013-9549-4

Wakefield, M. E., Bryning, G. P., Collins, L. E., and Chambers, J. (2005). Identification of attractive components of carob volatiles for the foreign grain beetle, Ahasverus advena (Waltl): (Coleoptera: Cucujidae). J. Stored Prod. Res. 41, 239-253. doi: 10.1016/S0022-474X(04)00027-X

Walter, D. E. (1996). Living on leaves: mites, tomenta, and leaf domatia. Annu. Rev. Entomol. 41, 101-114. doi: 10.1146/annurev.en.41.010196.000533
Walter, D. E., and O'Dowd, D. J. (1992a). Leaf morphology and predators: effect of leaf domatia on the abundance of predatory mites (Acari: Phytoseiidae). Environ. Entomol. 21, 478-484. doi: 10.1093/ee/21.3.478

Walter, D. E., and O'Dowd, D. J. (1992b). Leaves with domatia have more mites. Ecology 73, 1514-1518. doi: 10.2307/1940694

Walters, K. F. A., and Hardwick, N. V. (2000). "Principles of pest and disease management in crop protection," in Pest and Disease Management Handbook, ed D. V. Alford (Oxford: Blackwell Science), 1-18.

Wang, S. Y., Chi, H., and Liu, T. X. (2016). Demography and parasitic effectiveness of Aphelinus asychis reared from Sitobion avenae as a biological control agent of Myzus persicae reared on chili pepper and cabbage. Biol. Control 92, 111-119. doi: 10.1016/j.biocontrol.2015.10.010

Weber, R. W., and Nelson, H. S. (1985). Pollen allergens and their interrelationships. Clin. Rev. Allergy, 3, 291-318. doi: 10.1007/BF02992997

Weintraub, P., Kleitman, S., Mori, R., Gan-Mor, S., Ganot, L., and Palevsky, E. (2009). Novel application of pollen to augment the predator Amblyseius swirskii on greenhouse sweet pepper. IOBC/WPRS Bull. 50, 119-124.

Weiser, L. A., and Stamp, N. E. (1998). Combined effects of allelochemicals, prey availability, and supplemental plant material on growth of a generalist insect predator. Entomol. Exp. Appl. 87, 181-189. doi: 10.1046/j.1570-7458.1998.00319.x

Winkler, K., Wäckers, F. L., Kaufman, L. V., Larraz, V., and van Lenteren, J. C. (2009). Nectar exploitation by herbivores and their parasitoids is a function of flower species and relative humidity. Biol. Control 50, 299-306. doi: 10.1016/j.biocontrol.2009.04.009

Winkler, K., Wäckers, F. L., Termorshuizen, A. J., and van Lenteren, J. C. (2010). Assessing risks and benefits of floral supplements in conservation biological control. Biocontrol 55, 719-727. doi: 10.1007/s10526-010-9296-8

Wnuk, A., and Wojciechowicz-Zytko, E. (2007). Effect of intercropping of broad bean (Vicia faba L.) with tansy phacelia (Phacelia tanacetifolia Benth.) on the occurrence of Aphis fabae Scop. and predatory syrphidae. Aphids Other Hemipterous Insects 13, 211-217.

Wojciechowicz-Żytko, E., and Jankowska, B. (2016). Sambucus nigra L. as a reservoir of beneficial insects (Diptera, Syrphidae). Folia Hortic. 28, 209-216. doi: 10.1515/fhort-2016-0025

Wojciechowicz-Zytko, E., and Wnuk, A. (2012). The occurrence of Syrphidae in Aphis fabae Scop. (Hemiptera) colonies on broad bean intercropped with Phacelia (Part II). J. Plant Prot. Res. 52, 196-201. doi: 10.2478/v10045-012-0030-7

Wong, S. K., and Frank, S. D. (2012). Influence of banker plants and spiders on biological control by Orius insidiosus (Heteroptera: Anthocoridae). Biol. control 63, 181-187. doi: 10.1016/j.biocontrol.2012.07.001

Wong, S. K., and Frank, S. D. (2013). Pollen increases fitness and abundance of Orius insidiosus Say (Heteroptera: Anthocoridae) on banker plants. Biol. Control 64, 45-50. doi: 10.1016/j.biocontrol.2012.09.015

Xia, B., Zou, Z., Li, P., and Lin, P. (2012). Effect of temperature on development and reproduction of Neoseiulus barkeri (Acari: Phytoseiidae) fed on Aleuroglyphus ovatus. Exp. Appl. Acarol. 56, 33-41. doi: 10.1007/s10493-011-9481-1

Xiao, Y., Avery, P., Chen, J., McKenzie, C., and Osborne, L. (2012). Ornamental pepper as banker plants for establishment of Amblyseius swirskii (Acari: Phytoseiidae) for biological control of multiple pests in greenhouse vegetable production. Biol. Control 63, 279-286. doi: 10.1016/j.biocontrol.2012.09.007

Xiao, Y., Chen, J., Cantliffe, D., Mckenzie, C., Houben, K., and Osborne, L. S. (2011a). Establishment of papaya banker plant system for parasitoid, Encarsia sophia (Hymenoptera: Aphilidae) against Bemisia tabaci (Hemiptera: Aleyrodidae) in greenhouse tomato production. Biol. Control 58, 239-247. doi: 10.1016/j.biocontrol.2011.06.004

Xiao, Y., Osborne, L. S., Chen, J., Mckenzie, C., Houben, K., and Irizarry, F. (2011b). Evaluation of corn plant as potential banker plant for supporting predatory gall midge, Feltiella acarisuga (Diptera: Cecidomyiidae) against Tetranychus urticae (Acari: Tetranychidae) in greenhouse vegetable production. Crop Prot. 30, 1635-1642. doi: 10.1016/j.cropro.2011. 09.004

Yang, S., Wu, Y., Duan, Y., Jiang, Y., Shen, X., Liu, S., et al. (2009). Influence of prey species on growth, development and reproduction of Orius sauteri. Sci. Agricult. Sin. 42, 900-905. 
Yano, E. (2006). Ecological considerations for biological control of aphids in protected culture. Popul. Ecol. 48:333. doi: 10.1007/s10144-006-0008-2

Yano, E., Nishikawa, S., Yamane, M., and Abe, J. (2009). Development of the use of the banker plant system to control aphids in protected culture in Japan. IOBC/WPRS Bull. 49, 259-262

Yano, E., Toyonishi, H., Inai, K., and Abe, J. (2011). Development of a new banker plant system to control aphids in protected culture. IOBC/WPRS Bull. $68,195-198$

Yasukawa, H., Matsumura, M., Nakano, T., and Kurose, M. (2011). Effect of soil fumigation using chloropicrin and dazomet to reduce damage by Tyrophagus similis Volgin and fusarium wilt of spinach. Bull. Nara Prefectural Agricult. Exp. Station 1-6.

Ying, X. F., Run, M. Q., Shen, G., and Osborne, L. S. (2012). Banker plant system: a new approach for biological control of arthropod pests. Chin. J. Biol. Control $28,1-8$.

Yokoyama, V. Y. (1978). Relation of seasonal changes in extrafloral nectar and foliar protein and arthropod populations in cotton. Environ. Entomol. 7, 799-802. doi: 10.1093/ee/7.6.799

You, J., Zhu, F., Zhao, W., Zhao, X. E., Suo, Y., and Liu, S. (2007). Analysis of saturated free fatty acids from pollen by HPLC with fluorescence detection. Eur. J. Lipid Sci. Technol. 109, 225-236. doi: 10.1002/ejlt.200600224

Yue, B., Childers, C. C., and Fouly, A. H. (1994). A comparison of selected plant pollens for rearing Euseius mesembrinus (Acari: Phytoseiidae). Int. J. Acarol. 20, 103-108. doi: 10.1080/01647959408684008

Yue, B., and Tsai, J. H. (1996). Development, survivorship, and reproduction of Amblyseius largoensis (Acari: Phytoseiidae) on selected plant pollens and temperatures. Environ. Entomol. 25, 488-494. doi: 10.1093/ee/25.2.488

Zemek, R., and Prenerová, E. (1997). Powdery mildew (Ascomycotina: Erysiphales) - an alternative food for the predatory mite Typhlodromus pyri Scheuten (Acari: Phytoseiidae). Exp. Appl. Acarol. 21, 405-414. doi: 10.1023/A:1018427812075
Zhang, G., Zimmermann, O., and Hassan, S. A. (2004). Pollen as a source of food for egg parasitoids of the genus Trichogramma (Hymenoptera: Trichogrammatidae). Biocontrol Sci. Technol. 14, 201-209. doi: 10.1080/09583150310001655648

Zhang, N. X., Messelink, G. J., Alba, J. M., Schuurink, R. C., Kant, M. R., and Janssen, A. (2018). Phytophagy of omnivorous predator Macrolophus pygmaeus affects performance of herbivores through induced plant defences. Oecologia 186, 101-113. doi: 10.1007/s00442-017-4000-7

Zhao, J., Guo, X., Tan, X., Desneux, N., Zappala, L., Zhang, F., et al. (2017). Using Calendula officinalis as a floral resource to enhance aphid and thrips suppression by the flower bug Orius sauteri (Hemiptera: Anthocoridae). Pest Manag. Sci. 73, 515-520. doi: 10.1002/ps.4474

Zheng, Y., Daane, K. M., Hagen, K. S., and Mittler, T. E. (1993). Influence of larval food consumption on the fecundity of the lacewing Chrysoperla carnea. Entomol. Exp. Appl. 67, 9-14. doi: 10.1111/j.1570-7458.1993. tb01645.x

Zhou, W., and Wang, R. (1989). Rearing of Orius sauteri (Hem.: Anthocoridae) with natural and artificial diets. Chin. J. Biol. Control $5,9-12$.

Conflict of Interest: All authors were employed by company Biobest Group NV.

Copyright (C) 2020 Pijnakker, Vangansbeke, Duarte, Moerkens and Wäckers. This is an open-access article distributed under the terms of the Creative Commons Attribution License (CC BY). The use, distribution or reproduction in other forums is permitted, provided the original author(s) and the copyright owner(s) are credited and that the original publication in this journal is cited, in accordance with accepted academic practice. No use, distribution or reproduction is permitted which does not comply with these terms. 